\title{
Development and Testing of Matrices for the Encapsulation of Glass and Ceramic Nuclear Waste Forms
}
J. W. Wald
L. R. Bunnell
D. W. Brite
W. J. Gray
W. E. Gurwell
H. T. Blair
C. Q. Buckwalter
J. M. Rusin

February 1982

Prepared for the U.S. Department of Energy under Contract DE-AC06-76RLO 1830

Pacific Northwest Laboratory

Operated for the U.S. Department of Energy by Battelle Memorial Institute 


\title{
DISCLAIMER
}

This report was prepared as an account of work sponsored by an agency of the United States Government. Neither the United States Government nor any agency thereof, nor any of their employees, makes any warranty, express or implied, or assumes any legal liability or responsibility for the accuracy, completeness, or usefulness of any information, apparatus, product, or process disclosed, or represents that its use would not infringe privately owned rights. Reference herein to any specific commercial product, process, or service by trade name, trademark, manufacturer, or otherwise, does not necessarily constitute or imply its endorsement, recommendation, or favoring by the United States Government or any agency thereof. The views and opinions of authors expressed herein do not necessarily state or reflect those of the United States Government or any agency thereof.

\author{
PACIFIC NORTHWEST LABORATORY \\ operated by \\ BATTELLE \\ for the \\ UNITED STATES DEPARTMENT OF ENERGY \\ under Contract DE-AC06-76RLO 1830
}

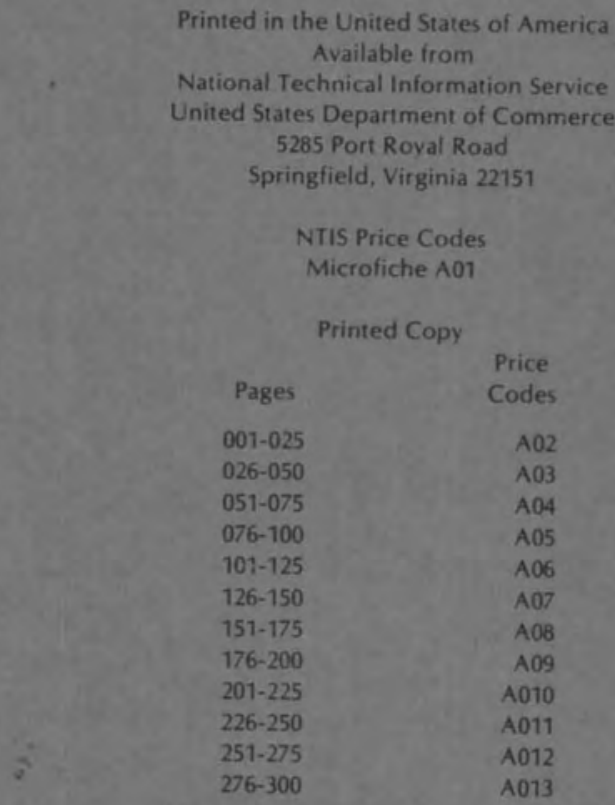


PNL -4098

UC -70

DEVELOPMENT AND TESTING OF MATRICES FOR

THE ENCAPSULATION OF GLASS AND CERAMIC

NUCLEAR WASTE FORMS

\author{
J.W. Wald \\ D.W. Brite \\ W.E. Gurwell 1 \\ C.Q. Buckwalter \\ L.R. Bunnell \\ W.J. Gray \\ H.T. Blair \\ J.M. Rusin
}

February 1982

Prepared for

the U.S. Department of Energy

under Contract DE-AC06-76RLO 1830

Pacific Northwest Laboratory

Richland, Washington 99352 


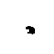

.

- 


\section{ABSTRACT}

This report details the results of research on the matrix encapsulation of high level wastes at PNL over the past few years. The demonstrations and tests described were designed to illustrate how the waste materials are effected when encapsulated in an inert matrix. Candidate materials evaluated for potential use as matrices for encapsulation of pelletized ceramics or glass marbles were categorized into four groups: metals, glasses, ceramics, and graphite. Two processing techniques, casting and hot pressing, were investigated as the most promising methods of formation or densification of the matrices. The major results reported deal with the development aspects. However, chemical durability tests (leach tests) of the matrix materials themselves and matrix-waste form composites are al so reported.

Matrix waste forms can provide a low porosity, waste-free barrier resulting in increased leach protection, higher impact strength and improved thermal conductivity compared to unencapsulated glass or ceramic waste materials. Glass marbles encapsulated in a lead matrix offer the most significant improvement in waste form stability of all combinations evaluated. This form represents a readily demonstrable process that provides high thermal conductivity, mechanical shock resistance, radiation shielding and increased chemical durability through both a chemical passivation mechanism and as a physical barrier. Other durable matrix waste forms evaluated, applicable primarily to ceramic pellets, involved hot-pressed titanium or $\mathrm{TiO}_{2}$ materials. In the processing of these forms, near $100 \%$ dense matrices were obtained. The matrix materials had excellent compatibility with the waste materials and superior potential chemical durability. Cracking of the hot-pressed ceramic matrix forms, in general, prevented the realization of their optimum properties. 



\section{CONTENTS}

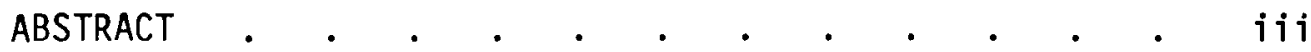

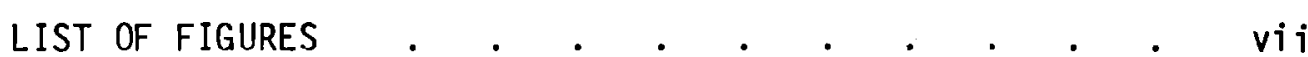

LIST OF TABLES • • • • • • • • • • • • • •

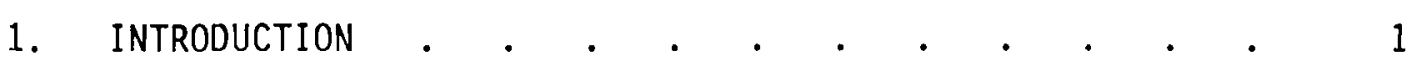

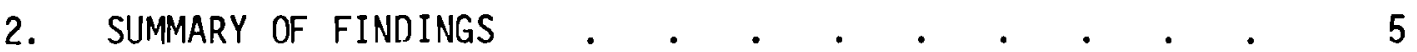

3. MATRIX DEVELOPMENT AND FABRICATION . • . . . . . 17

3.A Castable Metal Matrices J.W. Wald . . . . 17

Introduction . . . . . . . . . . 17

Processing and Fabrication . . . . . 17

Experimental . . . . . . . . 20

References . . . . . . . . . . 23

3.B. Hot Pressed Matrices W.E. Gurwell and D.W. Brite 25

Introduction . . . . . . . . . . . 25

Hot Pressing: Process Application . . . 26

Matrix Development . . . . . . . . 28

References . . . . . . . . . . 51

3.C. Graphite Matrices L.R. Bunnell and W.J. Gray . 53

Introduction . . . . . . . . . 53

Candidate Binders: Development and Fabrication 54

Permeability Apparatus . . . . . . 63

Permeability Results. . . . . . . 65

Leach Results: Matrix Materials . . . . 69

References . . . . . . . . . 71

3.D. Castable Ceramic Matrices D.W. Brite and H.T. Blair 73

Introduction . . . . . . . . . 73

Experimental . . . . . . . . . 75

References . . . . . . . . . 80

$\begin{array}{llll}\text { 4. CHEMICAL DURABILITY OF MATRIX FORMS } & \text { C. Q. Buckwalter } 83\end{array}$

Introduction . . . . . . . . . . 83 


\section{CONTENTS (continued)}

Experimental • • . . . . . . . . . 83

Results and Discussion . . . . . . . . 85

References . . . . . . . . . . 100

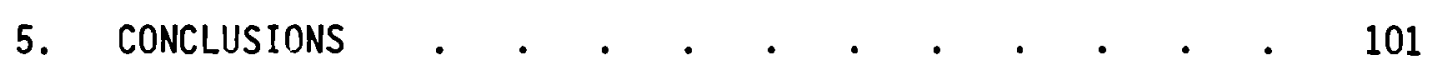

ACKNOWLEDGEMENT $. \quad . \quad . \quad . \quad . \quad . \quad . \quad . \quad . \quad . \quad 103$

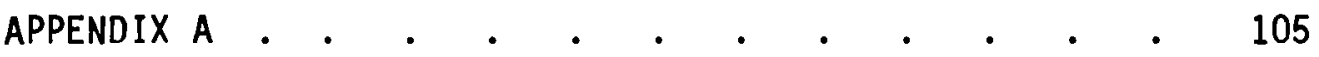




\section{LIST OF FIGURES}

1-1 Schematic of a Matrix Waste Form . . . . . 2

2-1 Summary of Matrix Development for Glass Marbles . $\quad 15$

2-2 Summary of Matrix Development for Ceramic Pellets . 16

3.A-1 Lab Scale Metal Matrix Casting Technique . $\quad$ - 18

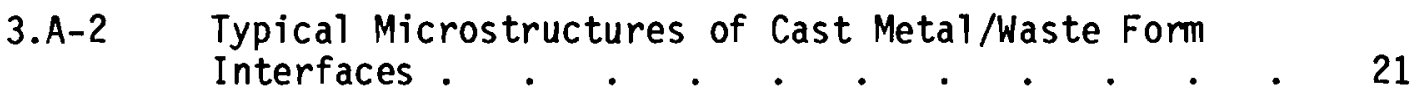

3.A-3 Analysis of Lead/Glass Interface . . . . . 23

3. B-1 Hot Pressed Matrix Waste Forms . . . . . 26

3.B-2 Conceptual Hot-Pressing Setup Cross Section . . 27

\begin{tabular}{l} 
3. B-3 Tycal Densification Behavior of Titanium and \\
Glass Matrices.. .5 \\
\hline
\end{tabular}

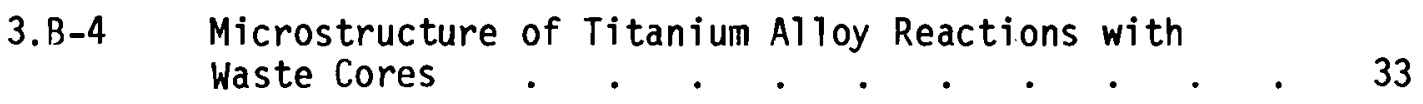

3.B-5 Microstructure of Waste Glass Marble Reactions with Aluminosilicate Glass (Code 1720) and Lead Glass

3.B-6 Microstructure of Supercalcine Pellet Reactions with Aluminosilicate Glass (Code 1720) and Lead Glass

3.B-7 Microstructure of Hot-Pressed SPC-4E Pellets

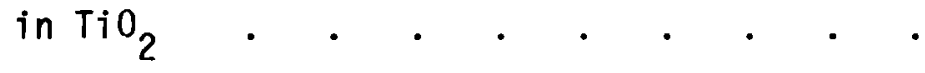

3.B-8 Microstructure of Hot-Pressed SPC-4E Pellets

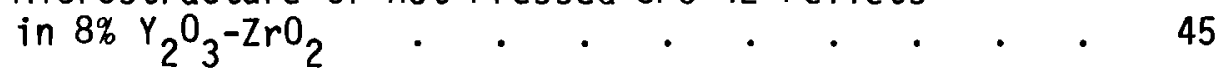

3.B-9 Hot-Pressing Densification Behavior of Supercalcine and Ceramic Matrices . . . . . 46

3.C-1 Graphite Matrix Rods with $3 \mathrm{~mm}$ dia. Glass Beads . . 55

3.C-2 Flow Chart of Process Used by G.A. to Produce Beads Embedded in a Graphite Matrix . . . . 57

3.C-3 Flow Chart Used by NUKEM to produce NiSBonded Graphite 


\section{LIST OF FIGURES (continued)}

3.C-4 NiS-Bonded Graphite Compact Produced by NUKEM . . 60

3.C-5 High-Magnification SEM Micrograph of the Center of Figure 3.C-4 .

3.C-6 NiS-Bonded Graphite Sample Prepared at PNL (HP 19) Showing Several Unreacted Ni Particles. . . . 61

3.C-7 NiS-Bonded Graphite Using Milled Ni Powder . . . 61

3.C-8 NiS-Bonded Graphite Compact Containing Simulated Waste Glass Marbles . . . . . . . . 62

3.C-9 Micrograph of Figure 3.C-8 Showing Excel lent Glass-toMatrix Bond . . . . . . . . . . 62

3.C-10 Schematic Diagram of Water Permeability Measuring Device

3.D-1 Selected Ceramic Pellet and Glass Bead Waste Forms Encapsulated in Castable Ceramic Matrices . . . 79

4-1 Representative Diagram of Leach Containers Manufactured from Matrix Materials . . . . . . . . 84

4-2 Schematic Representation of Composite Matrix/Waste Form Configuration . . . . . . . . . 84

4-3 Silicon Release for Glass PNL 76-68 Leach Tested in $\mathrm{Cu}, \mathrm{Ti}, \mathrm{Sn}, \mathrm{Al}, \mathrm{Pb}$, Graphite and Teflon Leach Cells

4-4 Cross Section of Waste Glass Samples Showing Depletion Layers . . . . . . . . . . . . 89

4-5 Surface of 76-68 Waste Glass Exhibiting Growth of Lead Crystallites . . . . . . . . . 90

4-6 EDAX Analysis Illustrating Lead Detected at All

Positions in Figure 4-5 


\section{LIST OF TABLES}

$2-1$

Basis for Matrix Material Selection . . . . 6

$2-2$

Phase Characterization Data for Matrix Waste Forms . 8

$2-3$

Thermal Stability of Matrix Waste Forms . . . 9

2-4 Mechanical Impact Behavior of Metal Matrix Forms . 11

2-5 Cumulative Dose at 1000 Years, Calculated for Candidate Matrices Incorporating Glass Marbles at 55 Volume Percent . . . . . . . . 11

2-6 Leach Data for Matrix Encapsulated Glass 76-68 . . 12

2-7 Leach Data for Matrix Encapsulated SPC-4E Supercalcine 13

3.A-1 Summary of Cast Metal Matrix Samples Fabricated and Characterized on a Lab Scale . . . . . . . . 18

3.A-2 Summary of Cast Metal Matrix Runs Fabricated on a Full Scale Basis . . . . . . . . . 19

3.A-3 Thermal Expansion Coefficients for Castable Metal Matrix Waste Forms . . . . . . . . . 22

3.B-1 Compatibility of Hot-Pressed Matrices with Waste Cores 27

3.B-2 Summary of Hot-Pressed Titanium (Ti-6\% A7-4\% V) Matrix Development . . . . . . . . . 30

3.B-3 Summary of Hot-Pressed Lead Glass (Code 7570) Matrix Development . . . . . . . . . 35

3.B-4 Summary of Hot-Pressed Aluminosilicate Glass (Code 1720) Matrix Development . . . . . . . . . 36

3.B-5 Summary of Hot-Pressed Titania Matrix Development . 41

3.B-6 Summary of Hot-Pressed Zirconia Matrix Development . 42

3.B-7 Volume Reduction of Ceramic Matrices During HotPressing at $20.7 \mathrm{MPa}$. . . . . . . . 47

3.C-1 Permeability and Heat Treatment Results for Graphite Matrix Rods . . . . . . . . . . 56

3.C-2 Graphite Matrix Rods Containing Glass Beads . . 67 


\section{LIST OF TABLES (continued)}

3.C-3 Leach Test Results, NUKEM NiS-Bonded Graphite • . 70

3.D-1 Compositional Comparison of Castable Ceramic Matrix Candidates Studied . . . . . . . 77

3.D-2 Castable Matrix Materials Preparation Conditions . 78

4-1 Leachate Analyses From Matrix Cell Test Blanks . . 86

4-2 Surface Concentration (atom \%) of Elements for Glass 76-68 Leached in Deionized Water (From XPS Analysis) . . . . . . . . . . . . 92

4-3 Leach Data for Matrix Encapsulated 76-68 Glass in Units of Normalized Elemental Loss . . . . . 94

4-4 Leach Data for Matrix Encapsulated SPC-4E Supercalcine in Units of Normalized Elemental Loss . . . 95

4-5 Leaching Results for Simulated TDS-211 Spiked

Glass Beads . . . . . . . . . . . . 98

4-6 Leaching Results for Simulated TDS-211 Spiked

Glass Beads in Pb Matrix . . . . . . . . 99

A-1 Nominal Composition of Glass 76-68 . . . . . 107

A-2 Nominal Composition of Glass TDS-211 • . . . 108

A-3 Nominal Composition of SPC-4E Supercalcine . . 109

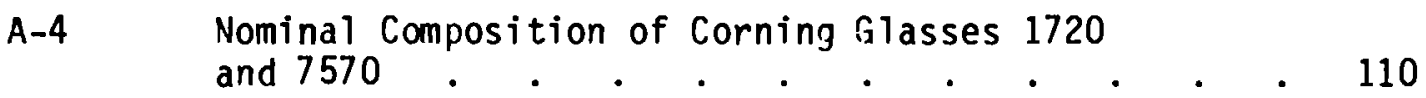




\section{INTRODUCTION}

For the past decade, Pacific Northwest Laboratory (PNL) has been developing and evaluating alternative waste forms for the immobilization of high-level nuclear wastes. The Alternative Waste Forms Program was established at PNL in 1979 for the Department of Energy to evaluate coated particles, matrix encapsulation, and glass ceramics as candidate waste forms. This report documents the studies that were conducted in the development of matrix waste forms within the PNL program. Similarly, efforts in coated particle, glass ceramic, and consolidation and sintering development have been documented el sewhere (Oma 1981, Rusin 1981, and Treat 1982).

Matrix waste forms are part of the multibarrier concept (Rusin, Browning and McCarthy 1979). The multibarrier concept aims to separate the radionuclide-containing core material and the environment by the use of coatings and/or matrices. The coating barrier can provide improved leach resistance and mechanical strength. The matrix can provide improved mechanical strength, leach resistance, and thermal conductivity. The matrix may either be used for direct containment of the waste-containing cores or as a barrier to the environment.

A schematic of a matrix waste form is shown in Figure 1-1, along with an illustration of it's key features (Gurwell 1981). A continuous "matrix web" can be established by controlling the waste core loading in the matrix, thereby effectively isolating individual waste cores. This matrix web is especially important if the cores contain porosity, are highly permeable, or if a void space exists between the cores and the matrix. The outer matrix envelope can be thought of as a separate barrier al though it is integral to the matrix. This waste-free skin or envelope provides a highly corrosion resistant barrier to the environment and creates a high strength package for containment. The matrix waste forms discussed in this report utilize some or all of the concepts illustrated in Figure 1-1.

Although considerable attention has been given to metal matrix waste forms, other materials such as graphite, ceramic oxides, and cements have been considered and are discussed within this report. Attention has been focused on metals such as lead, lead alloys, and aluminum and its alloys 
primarily due to ease of fabrication at low temperatures and high thermal conductivity. Due to currently anticipated lower heat content wastes, proposed centerline temperatures have been reduced and high thermal conductivity materials are not a major requirement. Containment from release by mechanical means and reduction or elimination of release by leaching is now of utmost importance. With this in mind, materials such as graphite, and selected ceramic oxides $\left(\mathrm{TiO}_{2}, \mathrm{Al}_{2} \mathrm{O}_{3}, \mathrm{ZrO}_{2}\right)$ became promising matrix candidates. Materials such as titanium and its alloys have also been considered due to the promise of high corrosion resistance.

The first part of this report contains sections describing the development and fabrication of various matrix samples containing either ceramic waste cores or waste glass marbles. These specifically include castable metal matrices ( $\mathrm{Pb}$ and $\mathrm{Al}-12 \% \mathrm{Si}$ ), hot pressed matrices ( $\mathrm{Ti}$, aluminosilicate glass, lead glass, $\mathrm{TiO}_{2}, \mathrm{Al}_{2} \mathrm{O}_{3}, \mathrm{ZrO}_{2}$ ), graphite matrices (with organic and inorganic binders), and castable ceramic matrices (calcium silicates, calcium aluminates). Leach resistance was the primary measurement used for matrix evaluation, and the last section of this report contains data and analysis on the leaching behavior of the various samples developed and fabricated under this program. In addition, bulk properties including density, porosity and thermal expansion were measured.

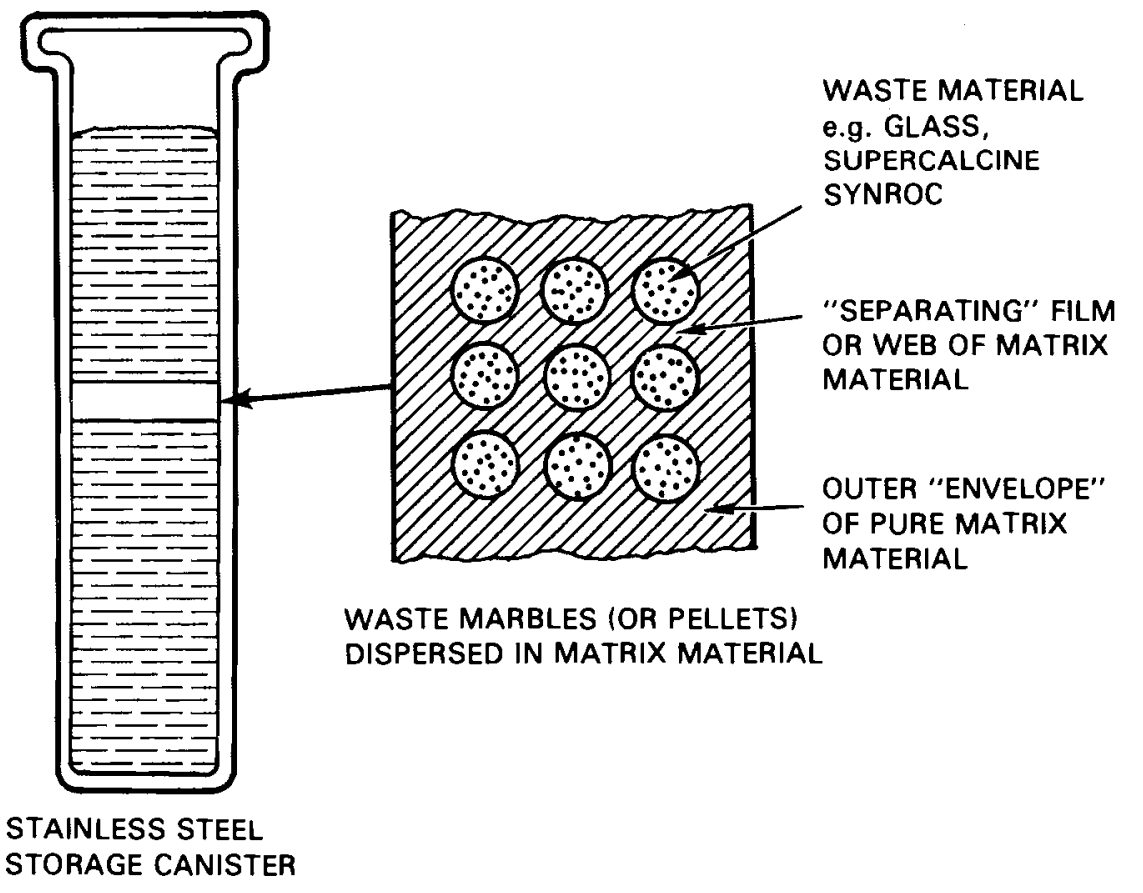

FIGURE 1-1. Schematic of a Matrix Waste Form 


\section{References}

Gurwel1, W. E. 1981. A Survey of Matrix Materials for Solidified Radioactive High-Level Waste, PNL-3512, Pacific Northwest Laboratory, Richland, WA 99352.

Oma, K. H. et al. 1981. Coated Particle Waste Form Development. PNL-4108, Pacific Northwest Laboratory, Richland, WA 99352.

Rusin, J. M. 1981. An Assessment of Glass Ceramic Waste Forms. PNL-3515, Pacific Northwest Laboratory, Richland, WA 99352.

Rusin, J. M., M. F. Browning and G. J. McCarthy. 1979. "Development of Multibarrier Nuclear Waste Forms," in Scientific Basis for Nuclear Waste Management, V1, G. J. McCarthy, ed., PTenum Press, New York, NY 10011.

Treat, R. L. et al. 1982. Consol idated Waste Form Development. PNL-4146, Pacific Northwest Laboratory, Richland, WA 99352. 
,

.

, 


\section{SUMMARY OF FINDINGS}

Matrix waste forms can offer a low porosity, waste-free barrier to the environment and provide increased leach protection, higher impact strength, and improved thermal conductivity. Candidate materials, evaluated for potential use as matrices for the encapsulation of pelletized ceramic or glass marble nuclear waste forms can be categorized into four groups: metals, glasses, ceramics, and graphite. Two processing techniques have been investigated as the most promising methods of formation or densification of these matrix materials: casting and hot pressing. In developing matrix waste forms, both product characteristics and processability should be taken into consideration to select the optimum combination for the particular waste material. Each potential combination of matrix material and processing condition has been found to offer some advantage over the others.

This section summarizes major findings of the developmental and characterization studies concerning matrix encapsulation of glass marbles and ceramic pellets.

Materials Selection Basis - The selection of materials for use as a matrix for dispersing glass or ceramic waste cores is dependent not only on matrix/ waste core compatibility but al so on environmental or chemical stability. The waste composite must be fabricated at temperatures amenable to the relatively low melting glass marble and must stand up to the most severe repository conditions expected for at least a 1000 year 1 ifetime. Table 2-1 lists many generic categories considered for matrix materials at PNL in the course of this study, along with their predominant advantages or disadvantages. The most advantageous of these materials were selected for further evaluation, and are the principle subject of this report. Compositional Analysis - The composition of the simulated waste materials which were encapsulated are listed in Appendix A. Tables A-1, 2 and 3 list the composition of the 76-68 and TDS-211 glass marbles and the SPC-4E supercalcine used in the matrix encapsulation and testing experimentation. The glass marbles were formed into $6 \mathrm{~mm}$ diameter cores by a drip technique and the supercalcine was formed into $8 \mathrm{~mm}$ diameter pellets by disc pelletization and sintering. The composition of the metallic and the nonmetallic matrices investigated, are given in the respective sections of Part 3 . 


\section{TABLE 2-1. Basis for Matrix Material Selection}

\begin{tabular}{|c|c|c|}
\hline Material & Advantage & Disadvantage \\
\hline Aluminum and Alloys & $\begin{array}{l}\text { Vacuum castable, ex- } \\
\text { cellent compatibility } \\
\text { with ceramic waste forms, } \\
\text { low cost, readily } \\
\text { avallable }\end{array}$ & \\
\hline Copper & & $\begin{array}{l}\text { High cost, excessive oxi- } \\
\text { dation above } 120^{\circ} \mathrm{C} \text {, fabri- } \\
\text { cation complexity }\end{array}$ \\
\hline Lead and Alloys & $\begin{array}{l}\text { Vacuum castable, ex- } \\
\text { cellent compatibility } \\
\text { with all waste forms, } \\
\text { radiation shielding }\end{array}$ & \\
\hline Manganese Bronze & & $\begin{array}{l}\text { High cost, high processing } \\
\text { temperature, fabrication } \\
\text { complexity, high open } \\
\text { porosity }\end{array}$ \\
\hline Nickel Base Alloys & & $\begin{array}{l}\text { High cost, high processing } \\
\text { temperature, fabrication } \\
\text { complexity }\end{array}$ \\
\hline Stainless Steels & & $\begin{array}{l}\text { High processing temperature } \\
\text { excessive scaling above } 67 \\
\text { fabrication complexity, } \\
\text { high open porosity }\end{array}$ \\
\hline Titaniun and Alloys & $\begin{array}{l}\text { Highly corrosion re- } \\
\text { sistant, hot pressed } \\
\text { at temperatures com- } \\
\text { patible with ceramic } \\
\text { waste forms, good mech- } \\
\text { anical strength }\end{array}$ & \\
\hline Ceranics & $\begin{array}{l}\text { Potential high leach } \\
\text { resistance and waste } \\
\text { form compatibility, } \\
\text { low material cost }\end{array}$ & $\begin{array}{l}\text { Fabrication complexity, } \\
\text { densification at reason- } \\
\text { able temperatures }\end{array}$ \\
\hline Commercial Glasses & $\begin{array}{l}\text { Broad waste form com- } \\
\text { patibility, readily } \\
\text { avallable at reason- } \\
\text { ably low cost }\end{array}$ & $\begin{array}{l}\text { Variable chemical } \\
\text { stability }\end{array}$ \\
\hline Graphite & $\begin{array}{l}\text { Excellent chemical } \\
\text { stability, high } \\
\text { themal conductivity }\end{array}$ & $\begin{array}{l}\text { Reduction of permeability } \\
\text { is difficult, low mechani- } \\
\text { cal strength }\end{array}$ \\
\hline Castable cements & Simple process & $\begin{array}{l}\text { High water permeability, } \\
\text { low radiation stability } \\
\text { and mechanical strength }\end{array}$ \\
\hline Polymers & & $\begin{array}{l}\text { Unknown radiation and } \\
\text { thermal stability }\end{array}$ \\
\hline
\end{tabular}


Phase Characterization - The physical characteristics of the matrix waste forms examined are listed in Table 2-2. Although PNL glass 76-68 and SPC-4E disc pelletized supercalcine were used as the simulated waste materials, the properties of matrix waste forms are in principle not heavily dependent upon the encapsulated waste core. The matrix concept is equally amenable to any waste material that can be produced in glass marble or ceramic pellet form. The matrix composite is normally typified by a single-phase component that completely encapsulates a pellet or waste core at a dilution of 50 to 64 volume percent.

Crystalline phases in the waste cores were determined by $x$-ray diffraction (XRD) analysis and volume fractions were estimated as listed in Table 2-2. Density and porosity measurements were determined by standard immersion techniques. Crystalline phases in the matrix materials were also verified by XRD. Matrix densities and porosities were determined by calculations based upon individual properties of the waste core and matrix materials. Thermal Stability - Table 2-3 lists data relative to thermal stability of the matrix waste forms evaluated. Candidate matrix materials have been selected from two standpoints: 1) compatibility with the waste core during fabrication; and 2) thermal expansion compatibility. Matrix waste forms are produced either at a temperature below that of the significant volatility range of the waste core material or by consolidation techniques where the entire system is enclosed and the volatile components are contained.

Investigations of waste core material/matrix interfacial reactions at formation temperatures generally indicate no adverse effects. Migration of waste species into the matrix and degradation of the waste core material are minimized by controlling process temperatures and times. With the appropriate selection and matching of waste and matrix materials, thermal stability of the waste core material can be improved.

Mechanical Strength - Although the application of impact tests and compression tests to nuclear waste forms has provided a guidel ine for mechanical strength evaluations, standardized testing of matrix type waste forms has presently not been fully developed. Separation of waste "fines" from matrix "fines" in some cases is either not possible or is extremely subjective in nature. 
TABLE 2-2. Phase Characterization Data for Matrix Waste Forms

\begin{tabular}{|c|c|c|c|c|c|}
\hline Waste Material & $\begin{array}{c}\text { Fabrication } \\
\text { Process } \\
\end{array}$ & Crystalline Phases & Volume Fraction & Density & Porosity \\
\hline $\begin{array}{l}76-68 \text { Glass } \\
\text { TDS-211 G1ass }\end{array}$ & Cast & (Vitreous) & $96-100 \%$ & $2.98 \mathrm{~g} / \mathrm{cm}^{3}$ & $<1 \%$ \\
\hline \multirow{6}{*}{$\begin{array}{l}\text { SPC- } 4 E \\
\text { Supercalcine }\end{array}$} & \multirow{6}{*}{$\begin{array}{c}\text { Disc } \\
\text { Pelletized }\end{array}$} & $\mathrm{Ca}(\mathrm{RE})_{8}\left(\mathrm{SiO}_{4}\right)_{6} \mathrm{O}_{2}$ & $\sim 35 \%$ & \multirow[t]{6}{*}{$3.9 \mathrm{~g} / \mathrm{cm}^{3}$} & \multirow[t]{6}{*}{$\sim 25 \%$} \\
\hline & & (Ce,, $\mathrm{Zr} \ldots)_{2}$ & $\sim 20$ & & \\
\hline & & $(\mathrm{Sr}, \mathrm{Ba}, \mathrm{Ca}) \mathrm{MoO}_{4}$ & $\sim 15$ & & \\
\hline & & $(\mathrm{RE}) \mathrm{PO}_{4}$ & $\sim 10$ & & \\
\hline & & $(\mathrm{Cs}, \mathrm{Na}) \mathrm{AlSt}_{2} \mathrm{O}_{6}$ & $\sim 5$ & & \\
\hline & & (uncrystallized) & $\sim 15$ & & \\
\hline Matrix Materials & $\begin{array}{l}\text { Fabrication } \\
\text { Process } \\
\end{array}$ & $\begin{array}{c}\text { Matrix Crystalline } \\
\text { Phases } \\
\end{array}$ & $\begin{array}{c}\text { Volume } \\
\text { Fraction Waste } \\
\text { Load } \\
\end{array}$ & $\begin{array}{l}\text { Matrix } \\
\text { Density }\end{array}$ & $\begin{array}{c}\text { Matrix } \\
\text { Porosity }\end{array}$ \\
\hline Lead & Cast & $\mathrm{Pb}$ & $64 \%$ & $11.34 \mathrm{~g} / \mathrm{cm}^{3}$ & 0 \\
\hline$T i-6 \%$ Al-4\%V & Hot Pressed & $\begin{array}{l}\alpha / \beta \text { Tf Metal } \\
\text { Solid Solution }\end{array}$ & 50 & 4.37 & $1.5 \%$ \\
\hline 7570 Glass & $"$ & (vitreous) & 50 & 5.42 & 0 \\
\hline $1720 \mathrm{Glass}$ & $"$ & (vitreous) & 50 & 2.52 & 0 \\
\hline Graphite & $\begin{array}{l}\text { Admix- } \\
\text { Compaction }\end{array}$ & c & 50 & $\sim 1.5$ & $33 \%$ \\
\hline $\mathrm{TiO}_{2}$ & Hot Pressed & Rutile & 50 & 4.21 & 0 \\
\hline $\mathrm{ZrO}_{2}$ & $"$ & $\mathrm{ZrO}_{2}$ (cubic) & 50 & 6.03 & $2 \%$ \\
\hline Al frax 66 & Cast & NA & 64 & 2.42 & $30 \%$ \\
\hline Cotronics 919 & $"$ & NA & 64 & 2.76 & $24 \%$ \\
\hline $\begin{array}{l}\text { Type II } \\
\text { Portl and Cement }\end{array}$ & $"$ & $\mathrm{Ca}(\mathrm{OH})_{2}, \mathrm{Ca}_{3} \mathrm{SiO}_{5}$ & 64 & 1.78 & $45 \%$ \\
\hline
\end{tabular}


TABLE 2-3. Thermal Stability of Matrix Waste Forms

\begin{tabular}{|c|c|c|c|}
\hline Waste Form & $\begin{array}{l}\text { Formation } \\
\text { Temperature }\end{array}$ & $\begin{array}{c}\text { Significant } \\
\text { Volatility Range } \\
\end{array}$ & Thermal Expansion \\
\hline $76-68$ Glass & $1050^{\circ} \mathrm{C}$ & $>800^{\circ} \mathrm{C}$ & $9 \times 10^{-6} /{ }^{\circ} \mathrm{C}$ \\
\hline$S P C-4 E$ & $1125^{\circ} \mathrm{C}$ & $>800^{\circ} \mathrm{C}$ & $9.3 \times 10^{-6} /{ }^{\circ} \mathrm{C}$ \\
\hline \multicolumn{4}{|l|}{ Matrix Material } \\
\hline Lead & $400^{\circ} \mathrm{C}$ & & $229 \times 10^{-6} /{ }^{\circ} \mathrm{C}$ \\
\hline $\mathrm{Ti}-6 \%$ A $1-4 \% \mathrm{~V}$ & $950^{\circ} \mathrm{C}$ & & $8.5 \times 10^{-6}$ \\
\hline 7570 Glass & $400^{\circ} \mathrm{C}$ & & $8.4 \times 10^{-6}$ \\
\hline 1720 Glass & $800^{\circ} \mathrm{C}$ & & $4.2 \times 10^{-6}$ \\
\hline Graphite & $<800^{\circ} \mathrm{C}$ & & $\sim 1$ to $5 \times 10^{-6}$ \\
\hline $\mathrm{TiO}_{2}$ & $<1200^{\circ} \mathrm{C}$ & & $7.6 \times 10^{-6}$ \\
\hline $\mathrm{ZrO}_{2}$ & $<1200^{\circ} \mathrm{C}$ & & $10.2 \times 10^{-6}$ \\
\hline Al frax 66 & $<850^{\circ} \mathrm{C}$ & & $5.4 \times 10^{-6}$ \\
\hline Cotronics 919 & $\sim 100^{\circ} \mathrm{C}$ & & $4.7 \times 10^{-6}$ \\
\hline $\begin{array}{l}\text { Type II Portland } \\
\text { Cement }\end{array}$ & $20^{\circ} \mathrm{C}$ & & N.A. ${ }^{(a)}$ \\
\hline
\end{tabular}

(a) N.A. = Not Available 
Although no mechanical testing was conducted in the present work, Rusin et a1. (1979) have conducted impact tests on two metal matrix forms incorporating supercalcine pellets and glass marbles. The added advantage of metal matrices in reducing the total waste released after impact was demonstrated as shown in Table 2-4. The metal matrix absorbed much of the impact energy and, consequently, reduced the effect of impact on the encapsulated waste core.

Radiation Stability - In the matrix waste form, the radionuclides are incorporated within the encapsulated waste core. Thus, the major radiation effects will occur to the encapsulated waste material with minimal effects on the inert matrix. The matrix itself will experience gamma radiation and will also be bombarded by alpha particles and recoil nuclei near the interface of the waste material and matrix. Although specific tests were not conducted on the candidate matrix materials, negligible change is expected in microstructural characteristics of the matrix as a result of radiation damage. In the case of brittle matrices, there is some potential for cracking caused by radiation induced expansion of the waste core.

Table 2-5 lists the cumulative ionizing radiation doses that would be received by the candidate matrix materials after 1000 years, based upon glass marbles of commercial or defense waste assuming a packing fraction of approximately 55 vol\%. Cumulative doses from ceramic pellets would be less than those presented for glass marbles. Calculations have shown that the alpha dose to the matrix, even in the thin layer just around each waste core, is negligible compared to the gamma dose (Gurwell, 1981). Chemical Durability - Leach test data for selected matrix waste forms is given in Tables 2-6 and 2-7 for 76-68 glass and SPC-4E supercalcine, respectively. These leach tests were conducted under static conditions in deionized water at $90^{\circ} \mathrm{C}$ for a time period of 14 days with a standard sample surface area to solution volume ratio of $10 \mathrm{~m}^{-1}$. The data is presented in terms of normalized grams of element in solution per square meter of surface area of the matrix monolith. Geometric surface area was used thoughout.

The leach results in Tables 2-6 and 2-7 can be misleading and the reader is referred to Section 4 for a discussion of how they are to be interpreted. In general, the leach resistance of glass was improved by 
TABLE 2-4. Mechanical Impact Behavior of Metal Matrix Forms

(Taken from Rusin et a1. 1979)

\begin{tabular}{llc}
\multicolumn{1}{c}{ Material } & Matrix & $\begin{array}{c}\text { Waste Release } \\
\mathrm{g} / \mathrm{cm}^{3} \times 10^{-4}\end{array}$ \\
\cline { 1 - 1 } $\begin{array}{l}\text { Hot Pressed SPC } \\
\begin{array}{c}\text { PyC/A1203 Coated } \\
\text { SPC }\end{array}\end{array}$ & $\begin{array}{c}\text { None } \\
\text { Stainless } \\
\text { Steel }\end{array}$ & 1600 \\
Glass & None & 114 \\
Glass Marbles & Pb-10\% Sn & 120
\end{tabular}

(a) Based on fines < $37 \mu \mathrm{m}$; $158 \mathrm{ft}-1 \mathrm{~b}$ impact; cylindrical form

TABLE 2-5. Cumulative Dose at 1000 Years, Calculated for Candidate Matrices Incorporating Glass Marbles at 55 Volume Percent

\begin{tabular}{|c|c|c|}
\hline & \multicolumn{2}{|c|}{ Cumulative Dose } \\
\hline Matrix & Commercial Waste & Defense Waste \\
\hline $\begin{array}{l}\text { Cement, } \\
\text { Graphite }\end{array}$ & $1.6 \times 10^{11}$ Rads & $8.5 \times 10^{9} \mathrm{Rads}$ \\
\hline $\begin{array}{l}\text { Alfrax } 66 \\
1720 \text { Glass } \\
\text { Cotronics } 919\end{array}$ & $1.4 \times 10^{11}$ & $7.2 \times 10^{9}$ \\
\hline $\mathrm{TiO}_{2}$ & $1.3 \times 10^{11}$ & $6.0 \times 10^{9}$ \\
\hline$T i-6 \%$ A $1-4 \% \mathrm{~V}$ & $1.1 \times 10^{11}$ & $5.3 \times 10^{9}$ \\
\hline $\begin{array}{l}7570 \mathrm{Glass} \\
\mathrm{ZrO}_{2}\end{array}$ & $9.8 \times 10^{10}$ & $4.5 \times 10^{9}$ \\
\hline Lead & $4.5 \times 10^{10}$ & $1.7 \times 10^{9}$ \\
\hline
\end{tabular}


TABLE 2-6. Leach Data for Matrix Encapsulated 76-68 Glass in Units of Normalized Elemental Loss $\left(a / m^{2} \cdot d\right)^{(a)}$

\begin{tabular}{|c|c|c|c|c|c|c|}
\hline Element & 76-68 Glass & $\begin{array}{l}76-68 \mathrm{Glass} \\
\text { in } 100 \% \mathrm{~Pb} \\
\end{array}$ & $\begin{array}{l}76-68 \text { Glass } \\
\text { in } 7570 \mathrm{Glass} \\
\end{array}$ & $\begin{array}{l}76-68 \text { Glass } \\
\text { in } 1720 \text { Glass } \\
\end{array}$ & $\begin{array}{l}\text { 76-68 Glass in } \\
\text { Type II Portl and } \\
\text { Cement } \\
\end{array}$ & $\begin{array}{c}76-68 \text { Glass in } \\
\text { Cotronics } 919 \text { Castable }\end{array}$ \\
\hline B & 1.05 & 0.05 & 22.09 & 0.56 & 0.13 & 11.64 \\
\hline $\mathrm{Ba}$ & 0.01 & 0.01 & 0.81 & 0.08 & 1.39 & -- \\
\hline $\mathrm{Ca}$ & 0.06 & 0.01 & 0.09 & 0.24 & 8.51 & 0.31 \\
\hline Cs & 1.08 & 0.02 & 0.01 & 0.40 & 1.51 & 0.07 \\
\hline Mo & 1.04 & 0.03 & 0.09 & 0.52 & 0.06 & 0.27 \\
\hline $\mathrm{Na}$ & 0.89 & 0.03 & 0.14 & 0.64 & 3.74 & 0.70 \\
\hline $\mathrm{Pb}$ & -- & 5.40 & 18.99 & -- & -- & -- \\
\hline Si & 0.66 & 0.01 & 0.04 & 0.31 & 0.02 & 0.96 \\
\hline$S r$ & 0.06 & -- & 0.02 & 0.13 & 14.33 & -- \\
\hline $\mathrm{pH}$ & 9.5 & 10.3 & 8.6 & 8.8 & 11.4 & 6.5 \\
\hline
\end{tabular}

(a) Static leach test: $90^{\circ} \mathrm{C}-14$ day, $\mathrm{SA} / \mathrm{V}=1 \mathrm{Om}^{-1}$, deionized $\mathrm{H}_{2} \mathrm{O}$ 

TABLE 2-7. Leach Data for Mafrix Encapsulated SPC-4E Supercalcine in Units of Normalized Elemental
Loss $\left(\mathrm{g} / \mathrm{m}^{2} \cdot \mathrm{d}\right)(\mathrm{a})$

\begin{tabular}{|c|c|c|c|c|c|c|c|c|c|c|}
\hline El ement & SPC-4E & $\begin{array}{l}\text { SPC-4E in } \\
100 \% \mathrm{~Pb}\end{array}$ & $\begin{array}{l}S P C-4 E \text { in } \\
A]-12 \% \text { Si } \\
\end{array}$ & $\begin{array}{r}S P C-4 E \text { in } \\
T 1-6 \% A T-4 \% V \\
\end{array}$ & $\begin{array}{l}\text { SPC }-4 E \text { in } \\
\text { Graphite }\end{array}$ & $\begin{array}{r}\text { SPC-4E in } \\
7570 \text { Glass } \\
\end{array}$ & $\begin{array}{r}\text { SPC-4E in } \\
1720 \mathrm{Gl} \text { ass } \\
\end{array}$ & $\begin{array}{c}\text { SPC-4E in } \\
\text { Type II Portland } \\
\text { Cement } \\
\end{array}$ & $\begin{array}{c}S P C-4 E \text { in } \\
\text { in TFO02 }\end{array}$ & $\begin{array}{c}\mathrm{SPC}-4 \mathrm{E} \text { in } \\
\text { in } \mathrm{ZrO} 02\end{array}$ \\
\hline A1 & 0.01 & 0.4 & 0.14 & 0.01 & 0.03 & 3.30 & 0.20 & 0.32 & 0.26 & 0.04 \\
\hline $\mathrm{Ca}$ & 0.53 & 0.05 & 0.06 & 0.14 & -- & 0.16 & 0.21 & 7.23 & 0.07 & 52.63 \\
\hline Cs & 0.26 & 0.69 & 0.66 & $<0.35$ & $<0.14$ & $<0.40$ & $<0.33$ & 1.01 & 0.25 & $<0.16$ \\
\hline $\mathrm{Na}$ & 2.06 & 54.65 & 32.34 & 9.20 & 0.87 & 19.05 & 7.50 & 67.43 & 17.94 & 368.28 \\
\hline $\mathrm{Pb}$ & -- & 0.19 & -- & -- & -- & 13.61 & -- & -- & -- & -- \\
\hline Si & 0.93 & 3.29 & 0.10 & 0.07 & 0.07 & 0.08 & 0.26 & 0.04 & 0.07 & 0.78 \\
\hline $\mathrm{Sr}$ & 0.50 & 0.01 & 0.09 & 0.46 & 0.01 & 0.15 & 0.06 & 2.03 & 0.004 & 48.00 \\
\hline
\end{tabular}

\footnotetext{
(a) Static leach test: $90^{\circ} \mathrm{C}-14$ days, $S A / V=1 \mathrm{~m}^{-1}$, defonized $\mathrm{H}_{2} \mathrm{O}$
} 
incorporating marbles into a matrix, but the leachability of supercalcine in a matrix was actually greater than supercalcine by itself. Results for 76-68 glass encapsulated in the lead matrix are the most promising. Improvement in leach resistance of the glass/lead matrix waste form is due in part to a chemical effect, and partly to a corrosion barrier effect. Matrix dissolution was observed for some materials (e.g., boron from 7570 glass matrix).

Matrix Waste Form Ranking - Figures 2-1 and 2-2 illustrate the ranking achieved in this work for glass marbles and ceramic pellets respectively. Three major areas were identified and used to eliminate candidate materials from final selection. Bars which end under the "Fabrication Compatibility" heading indicate that the particular form could not be developed because of waste material-matrix incompatibility. Likewise, those forms whose bars end under the "Matrix Permeability" heading indicate they could be fabricated but could offer no clear advantage because of high permeabilities to potential leach solutions. Other forms were eliminated due to poor leach resistance. Only two forms emerged as clearly offering a distinct improvement over the unencapsulated form.

Glass beads encapsulated in a lead matrix were seen to offer the most significant improvement in waste form stability of all combinations evaluated. This form represents a readily demonstrable process that provides high themal conductivity, mechanical shock resistance, radiation shielding and increased chemical durability through a chemical effect and by simple physical protection. For ceramic pellets, hot pressed titanium demonstrated excellent compatibility with the waste form and potentially superior barrier properties.

\section{$\underline{\text { References }}$}

Gurwell, W. E. 1981. A Survey of Matrix Materials for Solidified Radioactive High-Level Waste, Appendix A. PNL-3512, Pacific Northwest Laboratory, Richland, Washington.

Rusin, J. M., R. 0. Lokken and J. W. Wald. 1979. "Characterization and Evaluation of Multibarrier Nuclear Waste Forms," in Ceramics in Nuclear Waste Management, Proc. Int. Symp. A.C.S., Cincinnati, OH. CONF-790420. 


\begin{tabular}{l} 
MATRIX CANDIDATES \\
\hline HOT PRESSED METALS \\
Ti - $6 \%$ AI - $4 \% \mathrm{~V}$ \\
HOT PRESSED CERAMICS \\
$\mathrm{TiO}_{2}$ \\
$\mathrm{ZrO}_{2}$ \\
HOT PRESSED GLASSES \\
ALUMINOSILICATE \\
HIGH Pb \\
CASTABLE CERAMICS \\
TYPE II PORTLAND CEMENT \\
Al $\mathrm{O}_{3}$ BASE \\
MgO BASE \\
GRAPHITE \\
CASTABLE METALS \\
Pb \\
Pb - $10 \%$ Sn \\
AI - $12 \%$ Si
\end{tabular}

\begin{tabular}{ll}
$\begin{array}{c}\text { FABRICATION } \\
\text { COMPATIBILITY }\end{array}$ & $\begin{array}{c}\text { MATRIX } \\
\text { PERMEABILITY }\end{array}$ \\
\cline { 2 - 2 } UNACCEPTABLE & NOT TESTED \\
UNACCEPTABLE & NOT TESTED \\
UNACCEPTABLE & NOT TESTED \\
UNACCEPTABLE & \\
ACCEPTABLE & NOT TESTED \\
UNACCEPTABLE \\
$\begin{array}{l}\text { ACCEPTABLE } \\
\text { ACCEPTABLE }\end{array}$ \\
$\begin{array}{l}\text { ACCEPTABLE } \\
\text { UNACCEPTABLE }\end{array}$ \\
$\begin{array}{l}\text { ACCEPTABLE } \\
\text { UNACCEPTABLE }\end{array}$ \\
$\begin{array}{l}\text { UNACCEPTABLE } \\
\text { ACCEPTABLE }\end{array}$ & UNACCEPTABLE \\
ACCEPTABLE & \\
UNACCEPTABLE & ACCEPTABLE \\
& ACCEPTABLE \\
& NOT TESTED
\end{tabular}

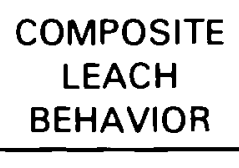

NOT TESTED

NOT TESTED NOT TESTED

NOT TESTED POOR

POOR

POOR

POOR

POOR

GOOD*

POOR

NOT TESTED

* OFFERS DISTINCT IMPROVEMENT OVER UNENCAPSULATED FORM 


\begin{tabular}{l} 
MATRIX CANDIDATES \\
\hline CASTABLE CERAMICS \\
TYPE II PORTLAND CEME \\
$\mathrm{Al}_{2} \mathrm{O}_{3}$ BASE \\
$\mathrm{MgO}$ BASE \\
CASTABLE METALS \\
$\mathrm{Pb}$ \\
$\mathrm{Pb}-10 \%$ Sn \\
AI - $12 \%$ Si \\
HOT PRESSED GLASSES \\
ALUMINOSILICATE \\
HIGH Pb
\end{tabular}

GRAPHITE

HOT PRESSED CERAMICS

$\mathrm{TiO}_{2}$

$\mathrm{ZrO}_{2}$

HOT PRESSED METALS

$$
\mathrm{Ti}-6 \% \mathrm{Al}-4 \% \mathrm{~V}
$$

\author{
FABRICATION \\ COMPATIBILITY
}

\begin{tabular}{c} 
MATRIX \\
PERMEABILITY \\
\hline
\end{tabular}

ACCEPTABLE

ACCEPTABLE

ACCEPTABLE

ACCEPTABLE

ACCEPTABLE

ACCEPTABLE

ACCEPTABLE

ACCEPTABLE

ACCEPTABLE

ACCEPTABLE

ACCEPTABLE

ACCEPTABLE
COMPOSITE

LEACH

BEHAVIOR

POOR

$\begin{array}{ll}\text { UNACCEPTABLE } & \text { POOR } \\ \text { UNACCEPTABLE } & \text { POOR }\end{array}$

$\begin{array}{ll}\text { UNACCEPTABLE } & \text { POOR } \\ \text { UNACCEPTABLE } & \text { POOR }\end{array}$

ACCEPTABLE

ACCEPTABLE

ACCEPTABLE

POOR

POOR

POOR

UNACCEPTABLE POOR

UNACCEPTABLE POOR

UNACCEPTABLE POOR

UNACCEPTABLE POOR

UNACCEPTABLE POOR

ACCEPTABLE POOR*

*OFFERS THE GREATEST POTENTIAL FOR IMPROVEMENT OVER UNENCAPSULATED FORM 
3. MATRIX DEVELOPMENT AND FABRICATION

3.A. CASTABLE METAL MATRICES

J.W. Wald

Introduction

The selection and evaluation of castable metals for a metal matrix waste form have chiefly centered about lead, aluminum and their respective alloys. These metals and alloys were initially chosen for their relatively low casting temperatures, and their high durability under expected environmental conditions. Early developmental work in this area has been outlined by Rusin et al. (1978). Lead and its alloys are considered most compatible with glass marble waste forms, although glass beads encapsulated in an aluminum matrix have been demonstrated (Nelson et al. 1981). Ceramic pellets, with their higher fabrication temperature, offer more latitude in metal selection and can be readily cast in an aluminum matrix, however, a lead matrix can be employed with equal ease. Since these cast matrices are essentially $100 \%$ dense, they have the potential to increase the thermal conductivity and impact strength of the encapsulated product. Aluminum and its alloys have higher thermal conductivity values, and higher strengths than lead alloys, but also require correspondingly higher processing temperatures. Although lead and its alloys can be processed at temperatures up to $200^{\circ} \mathrm{C}$ lower than aluminum, and its greater density can provide increased shielding, the increased weight may add difficulty in handling and transporting full sized canisters.

\section{Processing and Fabrication}

Table 3.A-1 summarizes the various castable alloy and waste form combinations that were fabricated and characterized on a laboratory scale in earlier work. Table 3.A-2 lists the metal/waste form combinations fabricated on a "full scale" basis, again as part of earlier work. In order to limit the present study of castable metal matrix waste forms, two specific alloys were chosen for examination: $100 \%$ lead and aluminum-12\% silicon. Borosilicate glass beads and supercalcine ceramic pellets were the two waste forms encapsulated.

Lab scale metal matrix specimens $(20-25 \mathrm{~mm}$ dia $\times 25-40 \mathrm{~mm}$ long) were fabricated by a vacuum casting technique as illustrated in Figure 3.A-1. 
TABLE 3.A-1. Sumary of Cast Metal Matrix Samples Fabricated and Characterized on a Lab Scale

\begin{tabular}{|c|c|c|c|c|c|}
\hline \multirow{2}{*}{$\begin{array}{c}\text { Matrix } \\
\text { Material } \\
\end{array}$} & \multicolumn{2}{|c|}{ Glass Beads } & \multirow{2}{*}{$\begin{array}{c}\text { Simulated Waste } \\
\text { Glass Marbles }\end{array}$} & \multicolumn{2}{|c|}{ Supercalcine } \\
\hline & Uncoated & A1-Coated & & Uncoated & Glass Coated \\
\hline A1 & $x$ & & & & \\
\hline $\mathrm{A} 1-12 \% \mathrm{Si}$ & $x$ & $x$ & $x$ & $x$ & $x$ \\
\hline $\mathrm{Al}-3.8 \% \mathrm{Mg}$ & $x$ & & & & \\
\hline $\mathrm{Pb}$ & $x$ & & $x$ & $x$ & \\
\hline $\mathrm{Pb}-10 \% \mathrm{Sn}$ & $x$ & $x$ & $x$ & $x$ & \\
\hline $\mathrm{Pb}-5 \% \mathrm{Sn}$ & $x$ & & $x$ & & \\
\hline $\mathrm{Pb}-6 \% \mathrm{Sb}$ & $x$ & & & & \\
\hline
\end{tabular}

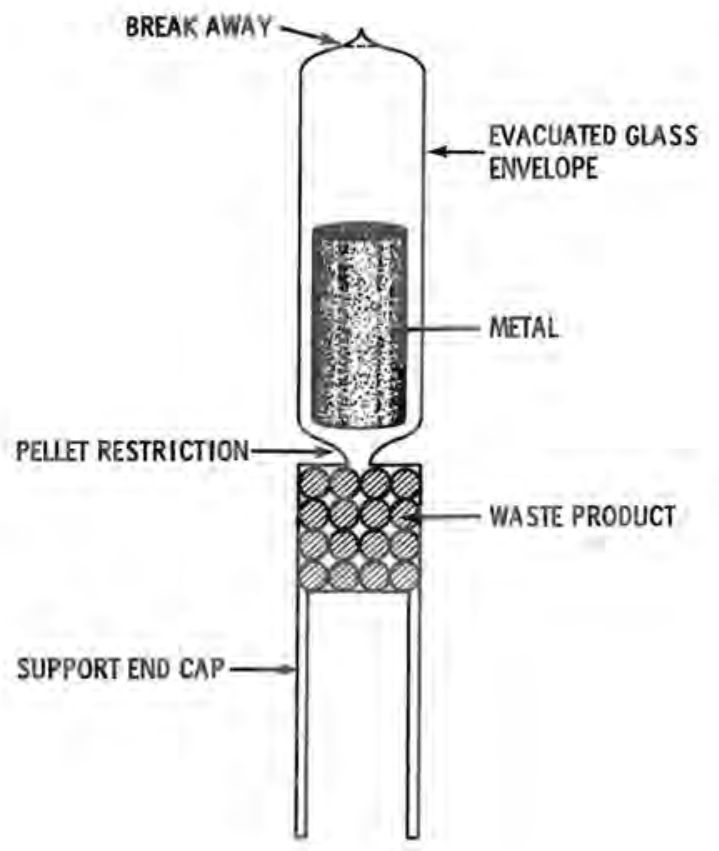

FIGURE 3,A-1. Lab Scale Meta] Matrix Casting Technique 
TABLE 3.A-2. Summary of Cast Metal Matrix Runs Fabricated on a Full Scale Basis(a)

\begin{tabular}{|c|c|c|c|c|}
\hline Matrix Alloy & Waste Form & $\begin{array}{c}\text { Pour } \\
\text { Temp., } \\
\text { oc } \\
\end{array}$ & $\begin{array}{l}\text { Preheat } \\
\text { Temp., }{ }^{\circ} \mathrm{C}\end{array}$ & Type of Pour \\
\hline $\mathrm{Pb}, 46 \mathrm{~kg}$ & None & 400 & None & Gravity \\
\hline $\mathrm{Pb}, .155 \mathrm{~kg}$ & $\begin{array}{l}\text { Mixture of waste- } \\
\text { glass marbles and } \\
\text { commerical lime } \\
\text { glass, } 34 \mathrm{~kg}\end{array}$ & 416 & 407 & Gravity \\
\hline $\mathrm{Pb}$ & $\begin{array}{l}\text { Waste-glass marbles, } \\
35 \mathrm{~kg}\end{array}$ & & & \\
\hline $\mathrm{Pb}, 182 \mathrm{~kg}$ & $\begin{array}{l}\text { Waste-glass marbles, } \\
35 \mathrm{~kg}\end{array}$ & 400 & 400 & Gravity \\
\hline $\begin{array}{l}\text { Pb } 10 \text { wt\% } \mathrm{Sn}, \\
66 \mathrm{~kg}\end{array}$ & None & 400 & None & Vacuum \\
\hline $\begin{array}{l}\text { Pb } 10 \mathrm{wt} \% \mathrm{Sn}, \\
178 \mathrm{~kg}\end{array}$ & $\begin{array}{l}\text { Waste-glass marbles, } \\
35 \mathrm{~kg}\end{array}$ & 400 & 400 & Vacuum \\
\hline $\begin{array}{l}\text { Pb-10 wt\% Sn, } \\
186 \mathrm{~kg}\end{array}$ & $\begin{array}{l}\text { Waste-glass marbles, } \\
34 \mathrm{~kg}\end{array}$ & 400 & 400 & Gravity \\
\hline $\begin{array}{l}\text { Al-12 wt\% Si, } \\
27 \mathrm{~kg}\end{array}$ & $\begin{array}{l}\text { Ceramic pellets, } 4 \mathrm{~kg} ; \\
\text { waste-glass marbles, } \\
1.5 \mathrm{~kg}\end{array}$ & 700 & $\begin{array}{l}700 \text { for ceramic } \\
\text { pellets, } 400 \\
\text { for glass mar- } \\
\text { bles }\end{array}$ & $\begin{array}{l}\text { Immersed capsules. } \\
\text { Filled by grav- } \\
\text { ity and vacuum }\end{array}$ \\
\hline $\begin{array}{l}\text { Al-12 wt\% } \mathrm{si} \text {, } \\
42 \mathrm{~kg}\end{array}$ & $\begin{array}{l}\text { Ceramic pellets, } 2 \text { to } \\
5 \mathrm{~mm} \text { dia, } 22 \mathrm{~kg}\end{array}$ & 700 & 700 & Vacuum \\
\hline $\begin{array}{l}\mathrm{A} 1-12 \text { wtx } \mathrm{Si} \text {, } \\
42 \mathrm{~kg}\end{array}$ & $\begin{array}{l}\text { Canister loaded same } \\
\text { as that in Heat No. } 9\end{array}$ & 700 & 700 & Vacuum \\
\hline $\begin{array}{l}\text { Al-12 wt: Si, } \\
9 \mathrm{~kg}\end{array}$ & None & 700 & 500 & Vacuum \\
\hline $\begin{array}{l}\text { Al-12 wt\% Si, } \\
8 \mathrm{~kg}\end{array}$ & None & 700 & 500 & Vacuum \\
\hline $\begin{array}{l}\text { Al-12 wt\% Si, } \\
11 \mathrm{~kg}\end{array}$ & $\begin{array}{l}\text { Ceramic pellets, } 2 \text { to } \\
5 \mathrm{~mm} \mathrm{dia}, 2.2 \mathrm{~kg}\end{array}$ & 730 & 500 & Vacuum \\
\hline $\begin{array}{l}\text { Al-12 wt\% Si, } \\
45 \mathrm{~kg}\end{array}$ & $\begin{array}{l}\text { Ceramic pellets, } 4 \\
\text { to } 9 \mathrm{~mm} \text { dia, } 34 \mathrm{~kg}\end{array}$ & 730 & 500 & Vacuum \\
\hline $\begin{array}{l}\mathrm{Pb}-3 \text { wt\%, Sb, } \\
8 \text { mm dia, } \\
175 \mathrm{~kg}\end{array}$ & $\begin{array}{l}\text { Simulated waste-glass } \\
\text { marbles, } 35 \mathrm{~kg}\end{array}$ & 400 & 400 & Gravity \\
\hline $\begin{array}{l}\text { Pb-3 wt\% Sb, } \\
179 \mathrm{~kg}\end{array}$ & $\begin{array}{l}\text { Waste-glass marble, } \\
35 \mathrm{~kg}\end{array}$ & 450 & 450 & Gravity \\
\hline $\begin{array}{l}\mathrm{Pb}-2 \mathrm{wt \%} \mathrm{Sb}, \\
3.3 \mathrm{~mm} \mathrm{dia}, \\
1429 \mathrm{~kg}\end{array}$ & $\begin{array}{l}\text { SRL TDS calcine and } \\
211 \text { frit, } 310 \mathrm{~kg}\end{array}$ & $\begin{array}{l}400- \\
450\end{array}$ & 450 & $\cdots$ \\
\hline
\end{tabular}

(a) Nelson et al. 1981 
The general procedure involves lowering the prefabricated assembly into a tube furnace preheated to the appropriate temperature, soaking for $30-45$ min. to completely melt the metal bar, and then snapping the glass envelope at the breakaway to allow an atmospheric pressure assist. Once this procedure has been accomplished the ampule is removed from the furnace and allowed to cool, at which time the glass envelope can be removed from the sample. With the unimportant exception of the use of glass as the envelope, this procedure closely duplicates the procedures used to fabricate full scale canisters.

\section{Experimental}

The microstructure of the metal matrix/waste form interface is illustrated in Figure 3.A-2 for four waste form combinations examined. It is recognized that this microstructure will be dependent to some extent on the cooling rates of the samples after casting, and that while these samples are all approximately the same size and were cooled at approximately the same rate $\left(\sim 10^{\circ} \mathrm{C} / \mathrm{min}\right)$, they most likely cooled at a faster rate than would be expected in the full scale case. The respective thermal expansion coefficients are given in Table 3.A-3.

The glass-in-lead waste form is generally typified by a tight bond between the glass and the metal as illustrated, with some indication of the presence of lead in the glass at the interface as discussed later. There were occasional areas where a gap or shrinkage void did occur in the $100 \%$ lead system, but it was the exception rather than the rule. In the glass/ $\mathrm{Pb}-10 \% \mathrm{Sn}$ waste form, however, it was more common to observe the shrinkage void as illustrated by the dark band in the photomicrograph. The same type void is seen in the supercalcine-in-lead waste form with the space being $5-10 x$ as large as the $\mathrm{Pb}-10 \% \mathrm{Sn}$ system. In the supercalcine-in-AT-12\% $\mathrm{S} i$ waste form there is a hair line spacing between the metal and the waste form. This interface was seen to vary quite significantly throughout the sample but there was no indication of reactions between the supercalcine pellets and the metal. The examination of the waste pellet/matrix bond is important in metal matrix waste forms since separation or voids between the waste core and matrix may lead to increased solution paths in a leaching situation and/or a decrease in mechanical strength and thermal conductivity. 


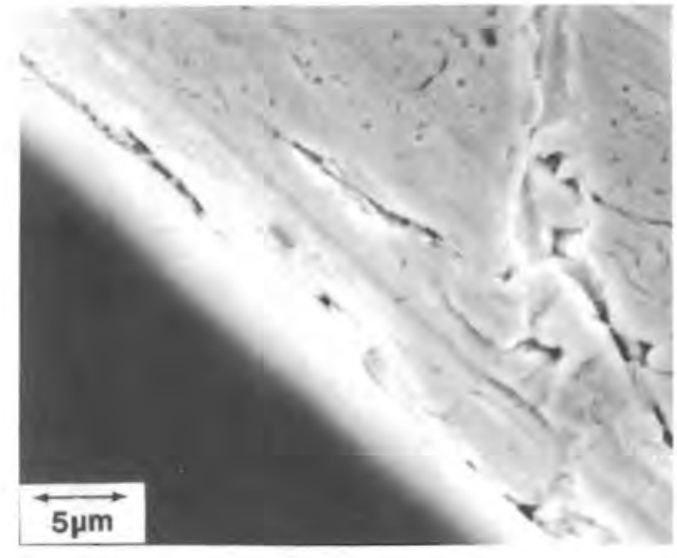

76-68 Glass in Pb

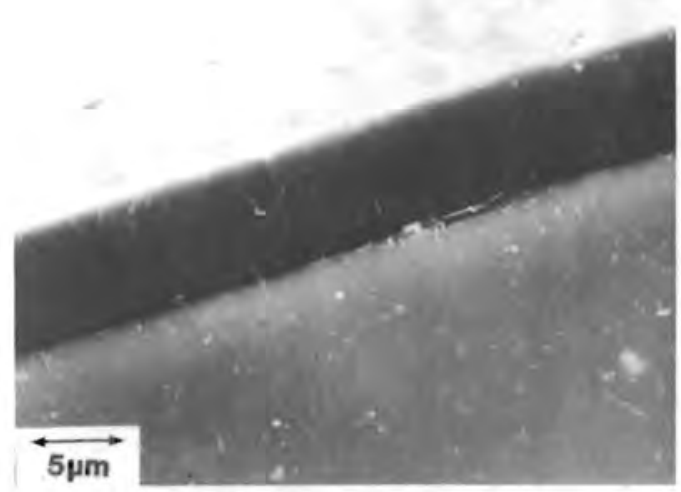

76-68 Glass in Pb-10\%Sn

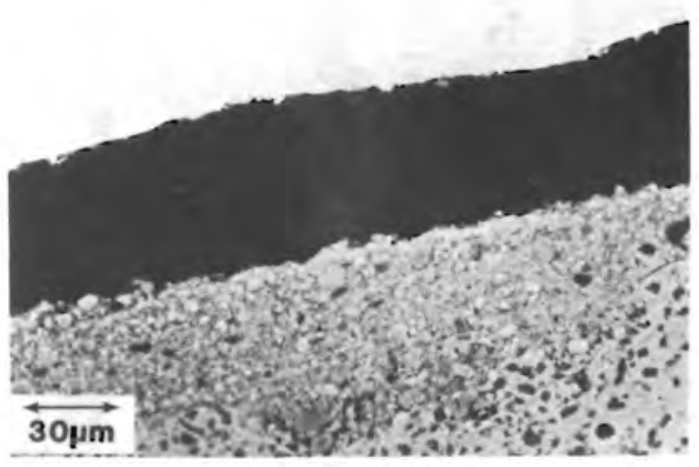

SPC-4E in $\mathrm{Pb}$

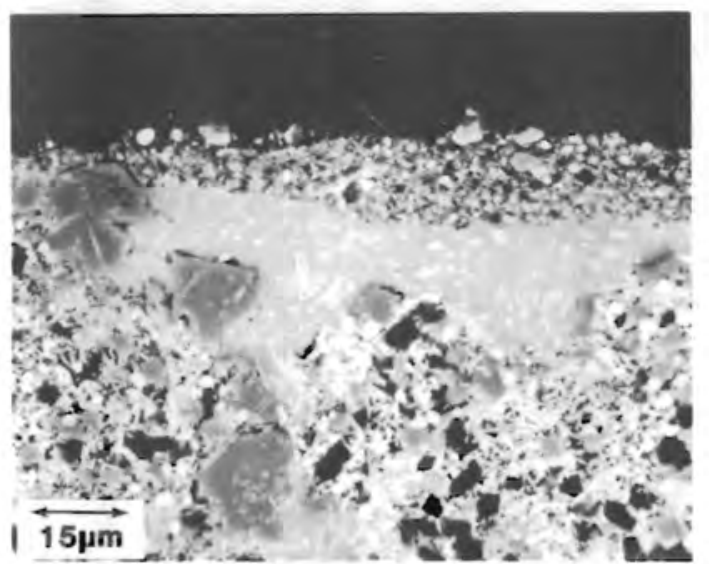

SPC-4E in A-12\%SI

FIGURE 3.A-2. Typical Microstructures of Cast Metal/Waste Form Interfaces 
TABLE 3.A-3. Thermal Expansion Coefficients for Castable Metal Matrix Waste Forms

\begin{tabular}{|c|c|c|}
\hline Material & Thermal Expansion & Range \\
\hline Glass $76-68$ & $9 \times 10^{-6} /{ }^{\circ} \mathrm{C}$ & $\left(\sim 50-500^{\circ} \mathrm{C}\right)$ \\
\hline SPC-4E Supercalcine & $9.3 \times 10^{-6} /{ }^{\circ} \mathrm{C}$ & $\left(20^{\circ}-1040^{\circ} \mathrm{C}\right)$ \\
\hline $100 \% \mathrm{~Pb}$ & $29.3 \times 10^{-6} /{ }^{\circ} \mathrm{C}$ & $\left(15-110^{\circ} \mathrm{C}\right)$ \\
\hline $\mathrm{Pb}-10 \% \mathrm{Sn}$ & $27.8 \times 10^{-6} /{ }^{\circ} \mathrm{C}$ & $\left(15-110^{\circ} \mathrm{C}\right)$ \\
\hline $\mathrm{Al}-12 \% \mathrm{Si}$ & $20.2 \times 10^{-6} /{ }^{\circ} \mathrm{C}$ & $\left(20-200^{\circ} \mathrm{C}\right)$ \\
\hline
\end{tabular}

Definite interactions between the waste material and the cast metal were observed only for the glass-in-lead system. Figure 3.A-3 illustrates the interface analysis performed using scanning electron microscopy (SEM). A bright band approximately $2 \mu \mathrm{m}$ wide was observed in the glass marble after fabrication and cooling. Examination of this band indicated the presence of lead in the glass as illustrated. Although reactions of lead with glass have been noted, this observation was not expected as it occurred well below $\left(400^{\circ} \mathrm{C}\right)$ the glass transition temperature. More detailed leadglass interaction studies were made, however those results are not within the scope of this report.

In summary, the glass-in-lead waste form system represents the optimum castable metal matrix form, both from the standpoint of waste core compatibility, and also from the standpoint of a demonstrable fabrication process. The principle test used to evaluate these metal matrix waste forms was the chemical durability test, reported in Section 4. The results of this testing also support the glass-in-lead matrix stability. For many of these same reasons the Federal Republic of Germany directed its efforts toward the PAMELA-Process, a glass-in-lead matrix waste form, at a demonstration plant at the Eurochemic site at Mol, Bel gium (Heimerl 1979). 


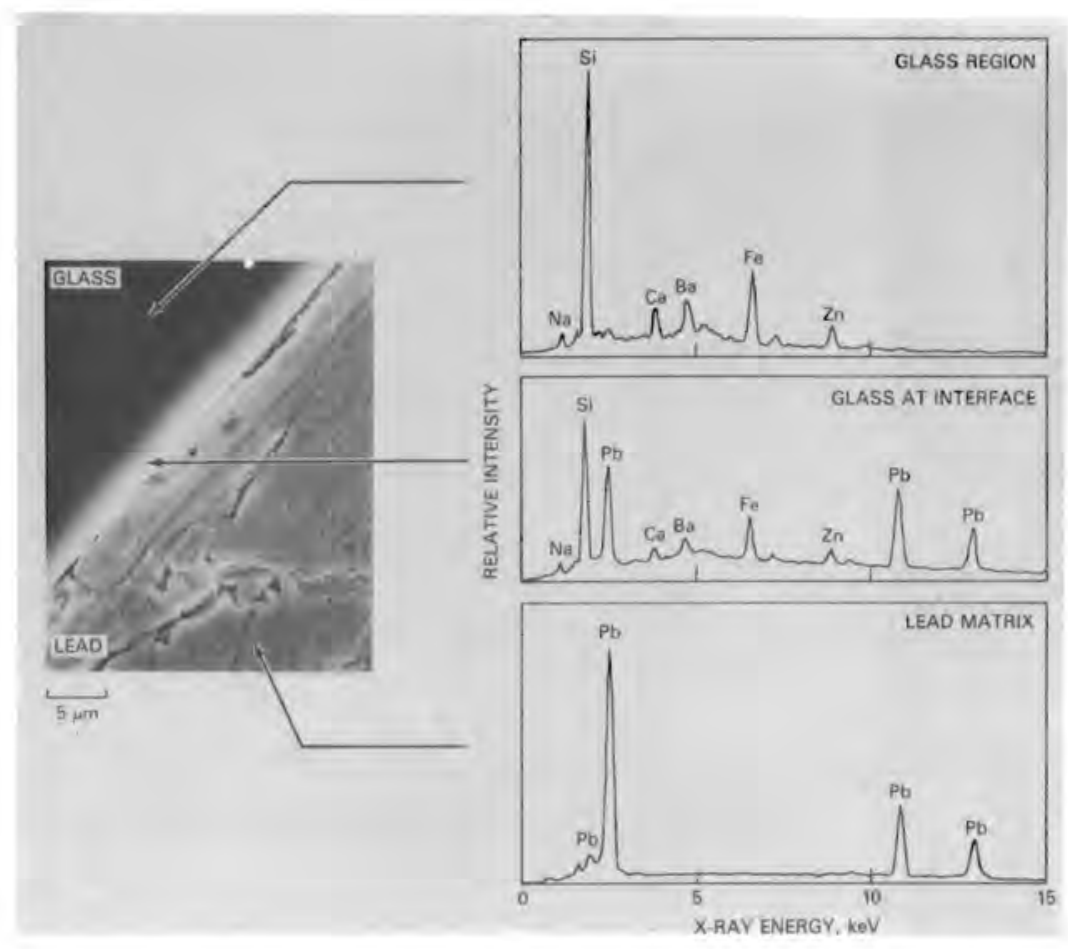

FIGURE 3.A-3. Analysis of Lead/Glass Interface

\section{References}

Heimerl, W. 1979. "Techniques for High Level Waste Solidification in Europe," in Scientific Basis for Nuclear Waste Management, V. 1, G. J. McCarthy, ed. PTenum Press, N.Y.

Nelson, R. G., J. F. Nesbitt and S. C. Slate. 1981. Nuclear Waste Encapsulation by Metal-Matrix Casting. PNL-3750, Pacific Northwest Laboratory, Richland, Washington.

Rusin, J. M., et al. 1978. Multibarrier Waste Forms Part I: Development. PNL-2668-1, Pacific Northwest Laboratory, Richland, Washington. 


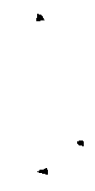




\section{B. HOT PRESSED MATRICES W. E. Gurwell and D. W. Brite}

Introduction

Powder processes such as hot-pressing (and hot-isostatic-pressing) are capable of forming high density, low permeability matrices from highly corrosion resistant materials, whose high melting points might otherwise preclude their use. Powder methods are also capable of producing a "separating web" of matrix material between the waste cores, as well as a wastefree skin on the outside edges of the form. The separating web of matrix encapsulates each waste core, effectively eliminating the penetration of water throughout the waste form via unbonded channels between the matrix and waste core ("wicking"). The waste-free skin provides a redundant barrier which would be effective in the event of failure of the primary canister.

Table 3.B-1 summarizes the matrix/waste core combinations examined in this work along with processing temperatures and the relative compatibilities with each waste core type. These combinations and processing conditions were chosen for a variety of reasons beyond the obvious objectives of high leach resistance. Glass waste cores were the least amenable, in general, to encapsulation by hot pressing. Most waste glasses are formed at $\sim 1100$ $1200^{\circ} \mathrm{C}$ with corresponding glass transition temperatures in the range of $500-700^{\circ} \mathrm{C}$. Hot pressing temperatures for the most desirable matrix material are well above the glass softening temperature, such that the glass cores are fluid enough (i.e., have sufficiently low viscosity) to infiltrate the powder matrix material. From the experiments completed, it appears that the waste glass viscosity must be at least $10^{4}$ poise at the hot-pressing temperature, to avoid infiltration. The temperatures at which the waste glasses have $10^{4}$ poise are about $825^{\circ} \mathrm{C}$ for $76-68$ and $725^{\circ} \mathrm{C}$ for TDS-211; only the lead glass matrix was fully compatible with these waste cores. All matrix materials studied were compatible with the SPC $-4 E$ cores. Only minor waste core/matrix interaction was observed and matrix cracking in the more brittle matrix materials was less than observed with glass cores because of slightly better thermal expansion compatibility. Simultaneous ceramic waste core consolidation and matrix densification was also demonstrated for the Code 1720 Glass matrix. 


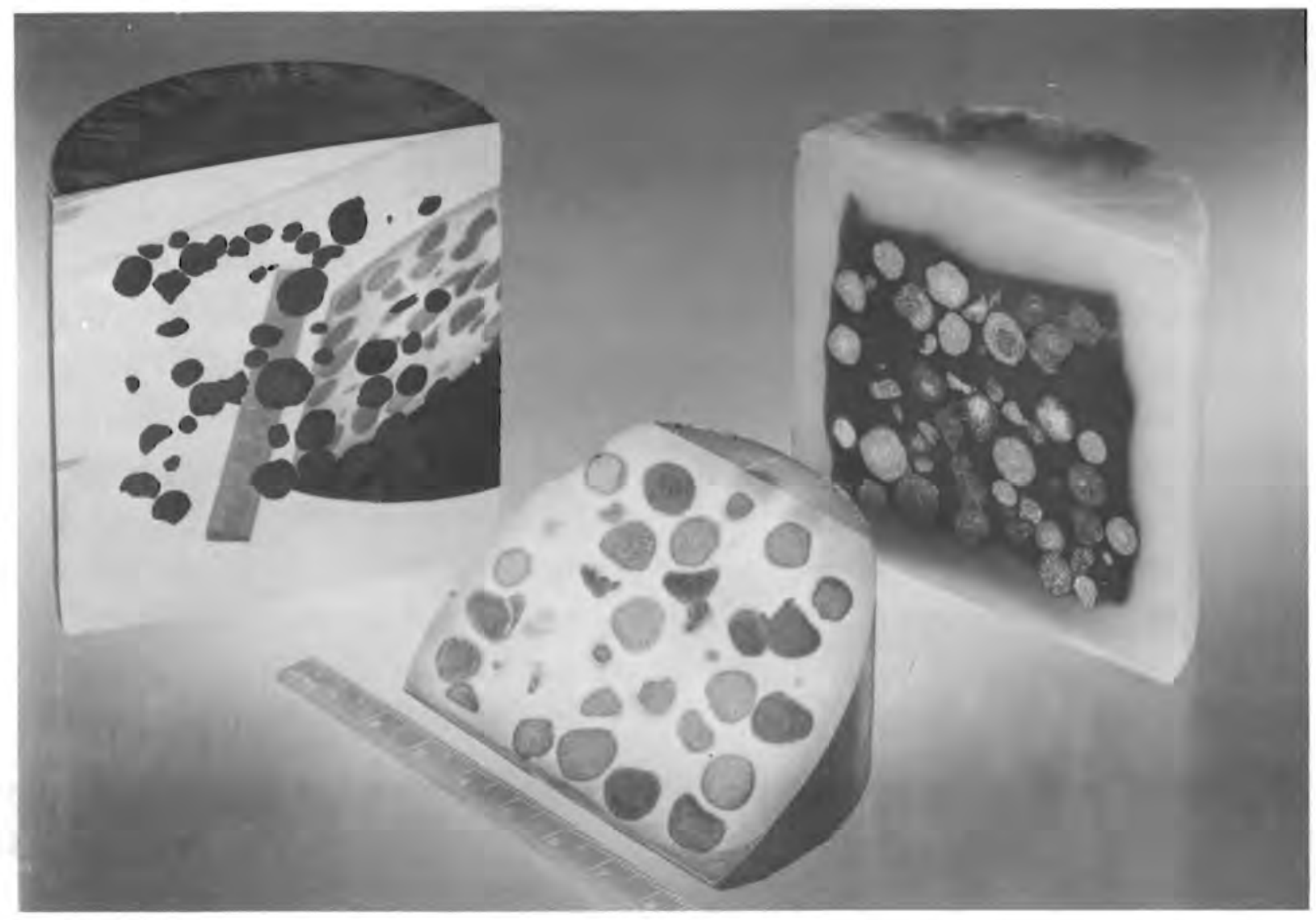

FIGURE 3.B-1. Hot Pressed Matrix Waste Forms

Cross-sections of some typical $7.6 \mathrm{~cm}$ diameter, hot-pressed matrix waste forms are shown in Figure 3.B-1. A random separation of the waste cores was achieved by intermixing the matrix powder and waste cores before placement in the hot-pressing die. All three waste forms contain SPC-4E as the waste core, with the matrices respectively shown in the figure from left to right: $\mathrm{Ti}-6 \% \mathrm{Al}-4 \% \mathrm{~V}, \mathrm{TiO}_{2}$, and code 1720 glass.

Hot Pressing: Process Application

Laboratory hot pressing in graphite dies is well known and has been described elsewhere (Seyboldt and Burke 1953; Thomas and Jones 1960). Although not generally thought of as a production process, hot pressing has been used to produce boron carbide body armor (Hansen 1969), and is the densification method proposed by Sandia for the titanate high-level radioactive waste form; the conceptual hot cell process is described by Treat et a1. (1980). 
TABLE 3.B-1. Compatibility of Hot-Pressed Matrices With Waste Cores

\begin{tabular}{|c|c|c|c|}
\hline \multirow[b]{2}{*}{ Matrix Material } & \multirow[b]{2}{*}{$\begin{array}{l}\text { Hot Pressing } \\
\text { Temperature }\end{array}$} & \multicolumn{2}{|c|}{ Waste Cores } \\
\hline & & $\begin{array}{c}\text { Supercalcine } \\
\text { SPC-4E }\end{array}$ & $\begin{array}{c}\text { Glass } 76-68 \text { or } \\
\text { TDS }-211\end{array}$ \\
\hline Titanium & $950^{\circ} \mathrm{C}$ & Good & $\begin{array}{l}\text { Waste glass infiltrates } \\
\text { titanium powder, but } \\
\text { envelope essentially } \\
\text { intact }\end{array}$ \\
\hline $\begin{array}{l}\text { Aluminosilicate } \\
\text { Glass }\end{array}$ & $800^{\circ} \mathrm{C}$ & Good & $\begin{array}{l}\text { Extensive cracking } \\
\text { thermal expansion mismatc }\end{array}$ \\
\hline Lead Glass & $400^{\circ} \mathrm{C}$ & Good & Good \\
\hline Titania & $1200^{\circ} \mathrm{C}$ & $\begin{array}{l}\text { Moderate } \\
\text { Reaction }\end{array}$ & Not tested \\
\hline Zirconia & $1200^{\circ} \mathrm{C}$ & Good & Not tested \\
\hline
\end{tabular}

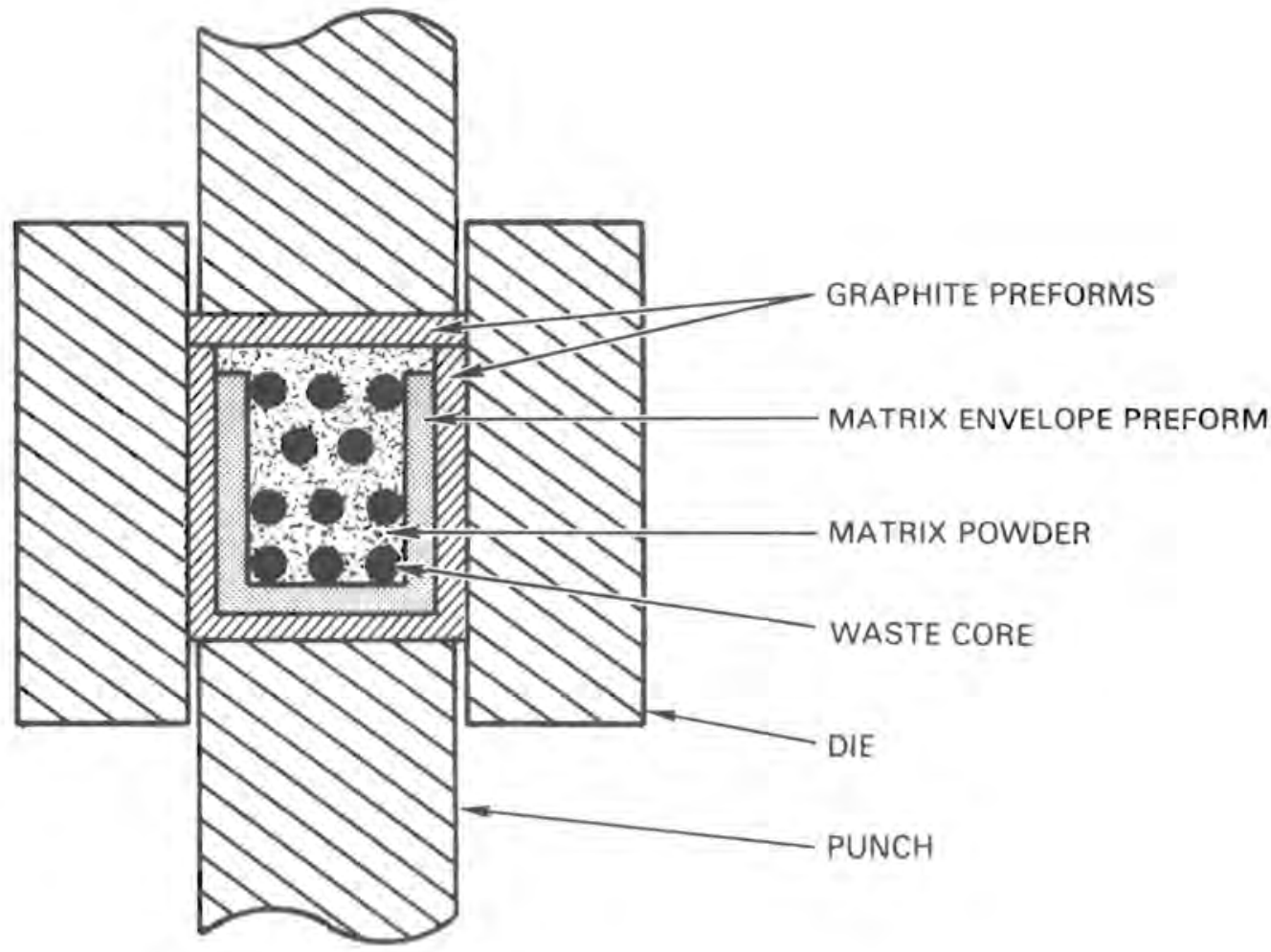

FIGURE 3.B-2. Conceptual Hot-pressing Set-up Cross Section 
A persistent problem with hot pressing is wear and oxidation and subsequent loss of strength in the graphite dies. Graphite is nevertheless almost always used because it is readily available, easy to machine, and maintains strength to high temperatures, if protected by a vacuum or inert atmosphere. For materials hot pressed below $1000^{\circ} \mathrm{C}$ (notably, titanium and glass) metal superalloy dies such as IN-100 or TRW-NASA VI A can be used in air (American Society for Metals 1980, p. 532) without atmosphere control. Die wear and galling can be eliminated by covering the pressing with graphite; this is incorporated in the conceptual hot pressing setup shown in Figure 3.B-2.

The conceptual setup uses graphite preforms, fabricated outside the hot cel1, to surround the entire pressing and become a permanent part of the hot pressing; these are low density to accommodate densification of the matrix powder. A matrix envelope preform, also of low density, of bonded matrix powder is used to simplify loading of the die. The die loading sequence would be: 1) The crucible shaped graphite and matrix envelope preforms (probably bonded together to handle as one piece) are placed in the die. 2) A proportioned mixture of matrix powder and waste cores is poured in, stopping at the upper end of the envelope preform. 3) Matrix powder is added to the upper end of the graphite crucible preform. 4) The graphite lid preform is placed on top and the compact is ready to press. The conceptual setup could be used with either graphite or metal dies. Graphite dies and vacuum or inert gas atmosphere would be required for the ceramic matrix materials.

Hot pressings are routinely fabricated with height to diameter ratios of $1 / 1$ and under proper conditions height to diameter ratios up to $2.5 / 1$ are probably practical. With these height to diameter ratios it would take 2 to 5 hot pressings, $61 \mathrm{~cm}(2 \mathrm{ft})$ diameter, to $\mathrm{fill}$ a $254 \mathrm{~cm}(10 \mathrm{ft}) \mathrm{high}$ canister.

\section{Matrix Development}

Only highly corrosion resistant materials, capable of providing a useful barrier to leach solutions, were considered. The candidate materials selected have been studied previously as engineered barriers (Westerman 1979; Fullam 1980; Westerman 1980; Charlot and Westerman 1981) or as barrier 
matrices (Gurwell 1981). To be considered for use as hot pressed matrices, materials should not only have satisfactory leach resistance, but also should be capable of being hot pressed to high density (high enough to preclude open porosity) at a temperature low enough to minimize loss of radioactive isotopes due to volatilization. Also, if glass waste marbles are to be encapsulated, the hot-pressing temperature must be below $800^{\circ} \mathrm{C}$ in order to prevent extrusion of the glass marble into the matrix. There are probably no oxide ceramics that meet these requirements for encapsulating glass marbles. However, several oxides have been hot pressed to suitable high densities at the $1200^{\circ} \mathrm{C}$ upper temperature limit considered feasible for processing disc pelletized and sintered supercalcine waste.

The following laboratory matrix development work was done in existing laboratory equipment. Graphite dies were used in either vacuum or argon atmospheres. The dies were lined with low density graphite foil (Grafoil)(a), $0.125 \mathrm{~mm}$ thick, which practically el iminated die wear.

Titanium - Of all the reasonable metal matrix choices, titanium has high corrosion resistance over the broadest range of environments; and for this reason, titanium offers superior barrier properties (Gurwel1 1981). Unalloyed titanium is not susceptible to stress corrosion cracking except in the extreme case of red fuming nitric acid; therefore, unalloyed or low alloy titanium, such as Ticode 12, is preferable for the barrier matrix.

Titanium has acceptable toughness (resistance to failure in the presence of a notch), and it is a good conductor of heat. On a volume basis titanium is roughly eight times as costly as lead and twenty times as costly as aluminum. The coefficient of thermal expansion of titanium $\left(8.5 \times 10^{-6} /{ }^{\circ} \mathrm{C}\right)$ should provide a good match with most waste cores. The titanium alloy powder used in this work was -35 mesh $\mathrm{Ti}-6 \% \mathrm{Al}-4 \% \mathrm{~V}$ made by the rotating electrode process ${ }^{(b)}$ which produces a spherical powder. Although chemically pure titanium is preferrable for stress-corrosion resistance, this alloy, which was readily available, was considered adequate for this preliminary development work.

(a) Union Carbide Corporation, New York.

(b) Nuclear Metals, Inc., Concord, Massachusetts. 
Table 3.B-2 summarizes titanium matrix hot pressing runs made with glass and supercalcine wastes. There appeared to be little difference in the densification behavior between compacts pressed in argon (1 atmosphere) or in vacuum (50 microns). The final density of a titanium matrix is relatively sensitive to pressure; that is $30 \mathrm{MPa}$ at $900^{\circ} \mathrm{C}$ produced a final density of $98 \%$ roughly equivalent to pressing at $10 \mathrm{MPa}$ and 1000 to $1100^{\circ} \mathrm{C}$. Even higher density, $99 \%$, is achieved with $150 \mathrm{MPa}$ at $900^{\circ} \mathrm{C}$. At $1200 \mathrm{MPa}$ and $800^{\circ} \mathrm{C}$ essentially $100 \%$ density was attained; such high pressure was obtained by "forging" the compact in an extrusion press.

TABLE 3.B-2. Summary of Hot Pressed Titanium (Ti-6\% A1-4\% V) Matrix Development (a)

\begin{tabular}{|c|c|c|c|c|c|}
\hline $\begin{array}{l}\text { Volume } \% \\
\text { Waste Core }\end{array}$ & ${ }^{\text {Temp. }} \mathrm{C}$. & $\begin{array}{l}\text { Pressure } \\
\mathrm{MPa} \\
\end{array}$ & $\begin{array}{l}\text { Time } \\
\text { min. }\end{array}$ & $\begin{array}{l}\text { Matrix } \\
\text { Density } \\
\text { \% Theo. }\end{array}$ & Comments \\
\hline & & & & $14.43 \mathrm{~g}$ & $\left.m^{3}=100 \%\right)$ \\
\hline none & 1000 & 10 & 60 & 96.7 & 50 micron vacuum \\
\hline none & 1100 & 10 & 60 & 98.5 & \\
\hline none & 900 & 150 & 30 & 99.3 & TZM die, $1.27 \mathrm{~cm}$ dia. \\
\hline none & 900 & 30 & 75 & 97.6 & TZM die, $1.27 \mathrm{~cm}$ dia. \\
\hline $\begin{array}{l}20 \% \text { TDS }-211 \\
20 \% \text { Flint Glass }\end{array}$ & 800 & 1200 & 0.2 & 100 & $\begin{array}{l}10.2 \mathrm{~cm} \text { dia. S.S. can in } \\
\text { extrusion press }\end{array}$ \\
\hline $34 \% S P C-4 E$ & 1100 & 10 & 75 & $\sim 99$ & $S P C-4 E$ densified to $\sim 4.4 \mathrm{~g} / \mathrm{cm}^{3}$ \\
\hline $35 \% S P C-4 E$ & 970 & 30 & 70 & น99 & $7.6 \mathrm{~cm}$ diameter scale-up \\
\hline
\end{tabular}

(a) Unless otherwise noted, all pressings done in $2.22 \mathrm{~cm}$ diameter graphite die. Vacuum atmosphere used in 7.6 and $10.2 \mathrm{~cm}$ diameter pressings. Argon atmosphere used in all others unless otherwise noted.

Pressures around $30 \mathrm{MPa}$ are practical for hot pressing in graphite dies; for this reason the $7.6 \mathrm{~cm}$ diameter demonstration titanium matrix waste form was pressed at $30 \mathrm{MPa}-970^{\circ} \mathrm{C}$. The densification behavior (see Figure 3.B-3) for this compact was typical of all the other pressings, with or without the supercalcine waste cores. The cross section of this compact 
pictured in Figure $3 . \mathrm{B}-1$ shows the $1 \mathrm{~cm}$ thick protective titanium envelope surrounding the entire waste form and a random separation of the supercalcine pellets. (On average the separation is about $2 \mathrm{~mm}$, equivalent to a $1 \mathrm{~mm}$ coating of titanium on each pellet.)

Upon hot-pressing the titanium matrix waste form at $1100^{\circ} \mathrm{C}$ and $10 \mathrm{MPa}$ the supercalcine pellets were densified to about $4.4 \mathrm{~g} / \mathrm{cm}^{3}$, nearly full density. Before hot pressing, the as-sintered pellets had a density of about $3.0 \mathrm{~g} / \mathrm{cm}^{3}$. No significant pel let densification was observed at $970^{\circ} \mathrm{C}$. Thin reaction layers formed between titanium and supercalcine pellets. At $1100^{\circ} \mathrm{C}$ the reaction layer is about 50 microns as shown in the lower micrograph of Figure 3.B-4.

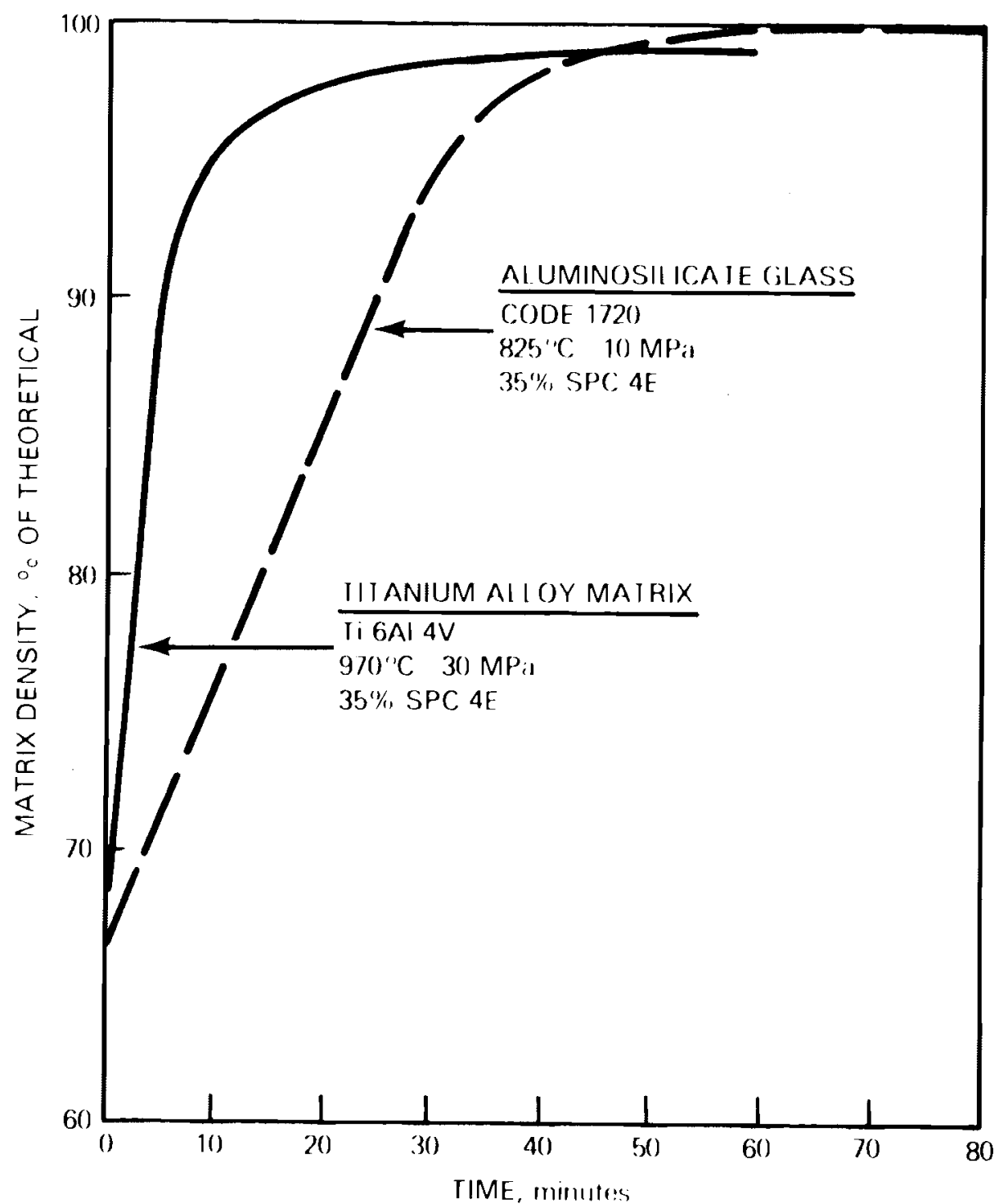

FIGURE 3.B-3. Typical Densification Behavior of Titanium and Glass Matrices 
Experiments were also undertaken to evaluate the possibility of hot pressing glass/titanium compacts, recognizing probable problems with regard to confining molten glass. Infiltration of the glass waste marbles into the titanium matrix depends largely upon the viscosity of the marble at hot pressing temperature as shown in the top two micrographs of Figure 3.B-4. Marbles having $10^{3}$ poise or less viscosity at the pressing temperature were fluid enough to almost completely infiltrate the coarse titanium powder matrix. However, the titanium envelope surrounding the entire waste form was essentially intact having suffered a small depth of infiltration by the waste glass. The resulting waste form is a dispersion of titanium powder particles in waste glass surrounded by an envelope of pure high density titanium alloy. It appears, based on these few experiments, that at reasonable pressing pressures of $30 \mathrm{MPa}$, a marble viscosity of roughly $10^{4}$ poise or greater is required to prevent significant infiltration. Thus a higher temperature waste marble could be made that would not infiltrate the titanium matrix.

One drawback in titanium powder metallurgy is that there can be a considerable fire and explosion hazard in large quantities of titanium powder as there is with any finely divided combustible material. Although titanium powders are now routinely handled, some consideration needs to be given to the effect of the hot waste core on titanium powder combustibility. Presumably, elimination of powder fines, and minimal contact with the air would be among the appropriate safety precautions.

Glass - Although the corrosion resistance of glasses is variable, depending upon composition and heat treatment, they are at least as durable as the waste cores. Glass matrices are fabricated by pressure sintering processes at lower temperatures than the normal temperatures for melting of waste glass or sintering of crystalline waste. Thus it is possible to match a high temperature glass (more durable) matrix with a lower temperature glass (less durable) waste core. The primary value of a glass matrix is in the barrier provided by the waste free outer envelope. A good bond is also formed between waste cores and glass matrices which can prevent wicking of leach solutions.

Glasses are brittle which requires careful attention to matching the thermal expansion characteristics of the matrix and waste core, as signifi- 

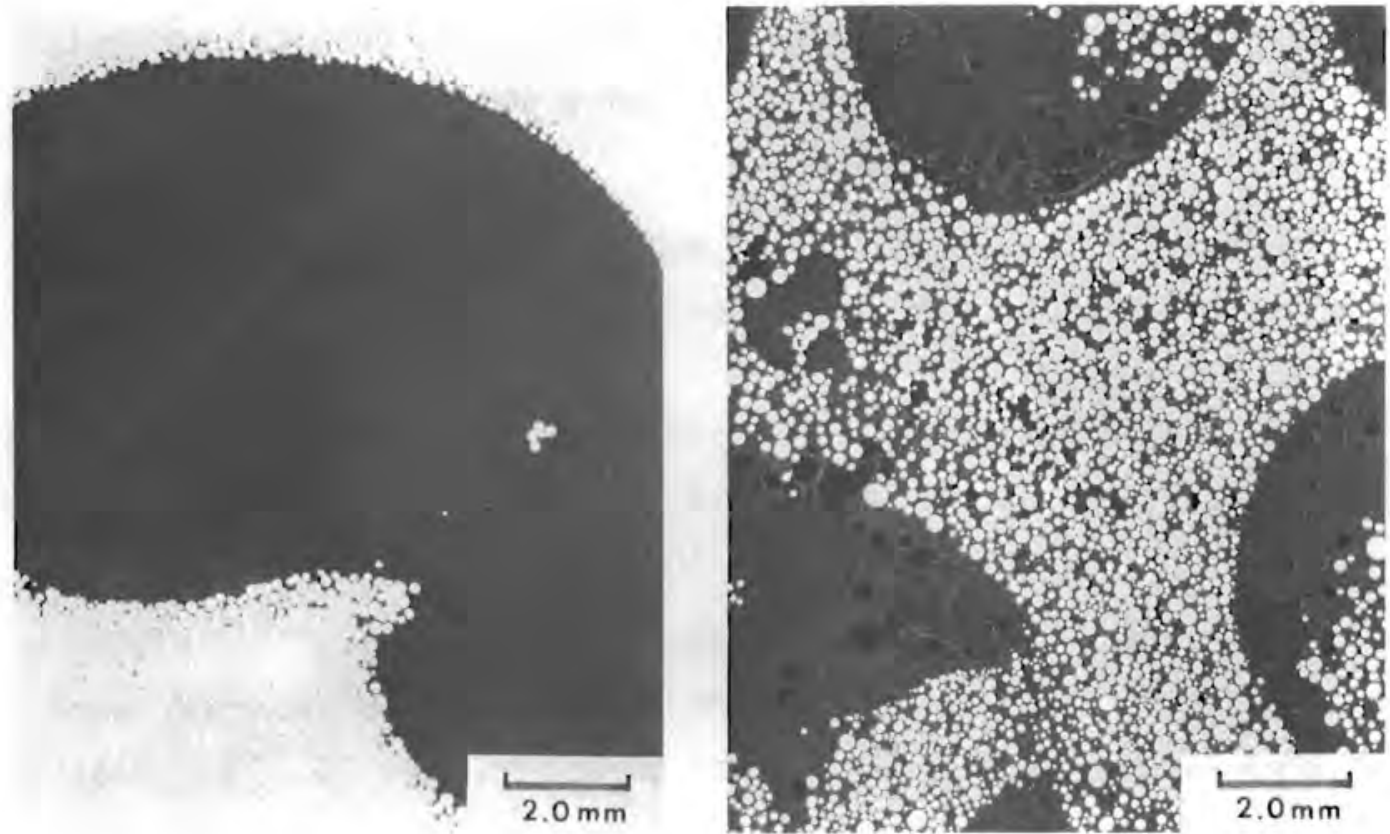

FLINT GLASS MARBLE $800^{\circ} \mathrm{C} \quad 1200 \mathrm{MPa} \quad 10$ Seconds $800^{\circ} \mathrm{C} \quad \frac{\text { TDS-211 GLASS }}{1200 \mathrm{MPa}}$ 10 Seconds

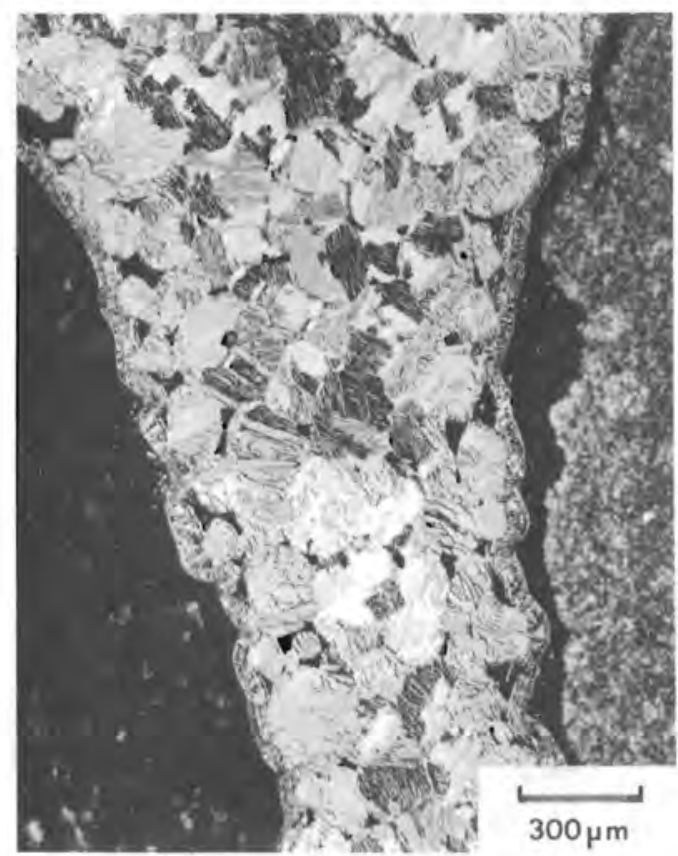

SUPERCALCINE SPC-4E

$1100^{\circ} \mathrm{C} \quad 10 \mathrm{MPa} \quad 50$ Minutes

FIGURE 3.B-4. Microstructure of Titanium Alloy Reactions with Waste Cores 
cant thermal gradients are generated during fabrication and storage. The properties of any glass can be tailored by adjusting chemical composition so that, in principle, well matched expansion coefficients could be obtained, though not undertaken in this study.

Two commercially available, -100 mesh, glass powders were chosen to illustrate a range of possibilities for the glass matrix:

1) a lead borosilicate glass, code $7570^{(a)}$, having a hot pressing temperature about $400^{\circ} \mathrm{C}$ and a thermal expansion $\left(9 \times 10^{-6} /{ }^{\circ} \mathrm{C}\right)$ that nearly matches that of the waste cores;

2) a lime magnesia aluminosilicate glass, code $1720^{(a)}$, having a hot pressing temperature of $800^{\circ} \mathrm{C}$ and anticipated superior leach resistance, but a low thermal expansion $\left(5 \times 10^{-6} /{ }^{\circ} \mathrm{C}\right)$ relative to the waste cores.

The densification behavior of these matrix glasses in either vacuum or argon atmosphere appeared to be about the same. Hot-pressing in graphite dies with a vacuum atmosphere produced a translucent matrix whereas hotpressing in an argon atmosphere produced a dark, opaque matrix. At $10 \mathrm{MPa}$ pressure, reasonable hot pressing temperatures are about midway between the softening point and annealing point, or about $10^{10}$ poise; at these temperatures densities of 99 to $100 \%$ of theoretical were achievable in less than an hour with and without waste cores in the matrix.

It was assumed that the fluid glass would develop hoop stresses in the die corresponding to ideally isostatic behavior of the glass. For this reason maximum pressing pressures in graphite dies were conservatively limited to $10 \mathrm{MPa}$; theoretically only small temperature increases are necessary to lower glass viscosity and speed up densification equivalent to increasing pressure. Some matrices cracked if cooled under pressure. Cracking was eliminated by removing the pressure at the annealing temperature for the matrix glass before cooling further.

The lead glass matrix development is summarized in Table 3.B-3. The general hot pressing behavior is as described above. The very low pressure

(a) Corning Glass Works, Corning, NY. 
TABLE 3.B-3. Summary of Hot Pressed Lead G1ass

(Code 7570) Matrix Development(a)

\begin{tabular}{|c|c|c|c|c|c|}
\hline $\begin{array}{r}\text { Volume\% } \\
\text { Waste Core } \\
\end{array}$ & $\begin{array}{c}\text { Temp. } \\
{ }^{\circ} \mathrm{C} \\
\end{array}$ & $\begin{array}{c}\text { Pressure } \\
\mathrm{MPa} \\
\end{array}$ & $\begin{array}{l}\text { Time } \\
\text { min. }\end{array}$ & $\begin{array}{l}\text { Matrix } \\
\text { Density } \\
\% \text { Theo. }\end{array}$ & Comments \\
\hline & & & & $15.42 \mathrm{~g} / \mathrm{cm}$ & $3=100 \%)$ \\
\hline None & 400 & 10 & 30 & 100 & \\
\hline None & 460 & 10 & 20 & 99.8 & . \\
\hline $40 \% \quad 76-68$ & 460 & 10 & 20 & 100 & \\
\hline $30 \% S P C-4 E$ & 460 & 10 & 25 & 99 to 100 & \\
\hline $35 \%$ TDS -211 & 500 & 1200 & 0.2 & 99.6 & $\begin{array}{l}10.2 \mathrm{~cm} \text { dia. can in extrusion } \\
\text { press }\end{array}$ \\
\hline $50 \%$ TDS -211 & 570 & 0.01 & 960 & 94.2 & $\begin{array}{l}9.65 \mathrm{~cm} \text { graphite die with small } \\
\text { weight on punches. Marbles } \\
\text { floated up to top due to } \\
\text { large density difference } \\
\text { between the matrix }\left(5.42 \mathrm{~g} / \mathrm{cm}^{3}\right) \\
\text { and the marble }\left(2.73 \mathrm{~g} / \mathrm{cm}^{3}\right)\end{array}$ \\
\hline
\end{tabular}

Ta) Unless otherwise noted, all pressings done in $2.22 \mathrm{~cm}$ diameter graphite die. Vacuum atmosphere used in 7.6 and $10.2 \mathrm{~cm}$ diameter pressings. Argon atmosphere used in all others unless otherwise noted.

experiment at $0.01 \mathrm{MPa}$ is illustrative of a sintering process; unfortunately the matrix viscosity (about $10^{4}$ poise at $570^{\circ} \mathrm{C}$ ) was low enough to allow the lower density waste marbles $\left(2.73 \mathrm{~g} / \mathrm{cm}^{3}\right)$ to float to the top of the matrix $\left(5.42 \mathrm{~g} / \mathrm{cm}^{3}\right)$ thus destroying the envelope. No attempt was made to determine if the sintering process could produce a dense matrix at temperatures sufficiently low to prevent floating. A very thin reaction layer forms between waste cores and the lead glass matrix as shown in the right photomicrograph of Figure 3.B-5; a typical 60 micron thick reaction layer with supercalcine is shown in the left photomicrograph of Figure 3.B-6. The thermal expansion match between this lead borosilicate glass matrix and supercalcine and waste glasses seem to be good; no significant cracking was observed. 
TABLE 3.B-4. Summary of Hot Pressed Aluminosilicate Glass

(Code 1720) Matrix Development (a)

\begin{tabular}{|c|c|c|c|c|c|}
\hline $\begin{array}{l}\text { Volume } \% \\
\text { Waste Core }\end{array}$ & ${ }^{\text {Temp }} \mathrm{C}$. & $\begin{array}{l}\text { Pressure } \\
\mathrm{MPa} \\
\end{array}$ & $\begin{array}{l}\text { Time } \\
\text { min. }\end{array}$ & $\begin{array}{l}\text { Matrix } \\
\text { Density } \\
\% \text { Theo. }\end{array}$ & Comments \\
\hline & & & & $12.52 \mathrm{~g} / \mathrm{cm}$ & $3=100 \%$ \\
\hline None & 785 & 10 & 60 & 100 & $\begin{array}{l}\text { Vacuum atmosphere }-110 \\
\text { microns } \mathrm{Hg}\end{array}$ \\
\hline None & 785 & 10 & 70 & 100 & \\
\hline None & 850 & 10 & 15 & 100 & \\
\hline $\begin{array}{ll}6 \% & \text { TDS }-211 \\
6 \% & 76-68\end{array}$ & 810 & 10 & 30 & 99.6 & $\begin{array}{l}\text { Marbles cracked severely } \\
\text { and some matrix cracking }\end{array}$ \\
\hline $42 \% 76-68$ & 810 & 10 & 50 & 100 & $\begin{array}{l}\text { Marbles and matrix cracked } \\
\text { severely }\end{array}$ \\
\hline $36 \%$ SPC $-4 E$ & 810 & 10 & 45 & 97 to 100 & \\
\hline $46 \%$ SPC-4E & 810 & 10 & 140 & $\sim 90$ & $\begin{array}{l}\text { Pellets stacked--prevented } \\
\text { full densification of matrix }\end{array}$ \\
\hline $\begin{array}{l}17 \% \text { uns intered } \\
\text { SPC-4E having } \\
2 \% \text { corn starch } \\
\text { binder }\end{array}$ & 1000 & 10 & 70 & 100 & $\begin{array}{l}\text { Pellets hot pressed to } \\
3.3 \mathrm{~g} / \mathrm{cm}^{3} 1720 \text { matrix is } \\
\text { about } 40 \% \text { crystalline }\end{array}$ \\
\hline $35 \% S P C-4 E$ & 825 & 10 & 80 & 100 & $7.62 \mathrm{~cm}$ diameter scale-up \\
\hline
\end{tabular}

(a) Untess otherwise noted, all pressings done in $2.22 \mathrm{~cm}$ diameter graphite die. Vacuum atmosphere used in 7.6 and $10.2 \mathrm{~cm}$ diameter pressings. Argon a tmosphere used in all others unless otherwise noted.

The aluminosilicate glass matrix development is summarized in Table 3.B-4. The general densification behavior was described above. A good bond forms between the aluminosilicate matrix and glass waste cores, but the thermal expansion mismatch between matrix $\left(5 \times 10^{-6} /{ }^{\circ} \mathrm{C}\right)$ and glass waste cores (about $10 \times 10^{-6}$ ) causes extensive cracking of both the matrix and waste core (see Figure 3.B-5, left); pressings containing about 40 volume percent glass waste cores crumbled under small mechanical loads. The low expansion 1720 matrix will plastically accommodate stresses above its transition temperature $\left(700^{\circ} \mathrm{C}\right)$, however, once the transition temperature 
of the glass bead is reached (in the range of $510^{\circ}-7000^{\circ} \mathrm{C}$ ), the glass bead will contract at almost twice the rate as the matrix. The resulting tensile stresses eventually exceed the bead strength which is less than the bond strength. The result is that the bead cracks extensively and the crack tips at the matrix-bead bond weaken the matrix which fractures with small applied forces. SPC-4E cores shrink uniformly at $\sim 10 \times 10^{-6} /{ }^{\circ} \mathrm{C}$; thus the total shrinkage is less than for 76-68 beads. However, with the SPC-4E beads in the 1720 matrix there is enough difference in thermal expansion to cause cracking at the bond which is, in this case, weaker than the SPC-4E core.

The photomicrograph in Figure 3.B-6 (left), shows a typical, uncracked, bond layer (about $60 \mu \mathrm{m}$ thick) between supercalcine and the aluminosilicate glass matrix. If the supercalcine pellets are not sintered before hot pressing there is a thicker reaction layer (about $250 \mu \mathrm{m}$ thick) and cracking occurs in the area in and near the matrix interface with the reaction layer as shown in Figure 3.B-6 (right). In this case, the cracking does not seem to degrade the matrix strength. The unsintered supercalcine pellets were not pressed in the glass matrix directly to demonstrate the possibility of eliminating the pellet sintering step; pressing conditions of $10 \mathrm{MPa}$ and $1000^{\circ} \mathrm{C}$ were chosen to obtain significant densification of the supercalcine. The pellets were densified from about $1 \mathrm{~g} / \mathrm{cm}^{3}$ to about $3.3 \mathrm{~g} / \mathrm{cm}^{3}$. The matrix was fully dense but about $40 \%$ crystalline due to the high hot pressing temperature.

In one additional experiment worth noting, 54 volume percent glass matrix and 46 volume percent supercalcine pellets about 1 cin diameter, were hot pressed in a $2.22 \mathrm{~cm}$ diameter die. Because of the confined space in the die the pellets stacked up to form a rigid structure which prevented full densification of the aluminosilicate glass matrix. This experiment does not relate directly to a full-scale waste form but it does emphasize that the amount of matrix powder used must be in excess of that required to fill the voids between a packed bed of waste cores.

A $7.6 \mathrm{~cm}$ diameter scale-up of the aluminosilicate glass matrix with 35 volume percent supercalcine pellets is shown in Figure 3.B-1. The cross section shows the $1 \mathrm{~cm}$ envelope and a random separation (averaging about 2 $\mathrm{mm}$ ) of the pellets. The matrix around the pellets is dark due to contamination from pellet dust introduced during mixing of the pellets and matrix powder. 


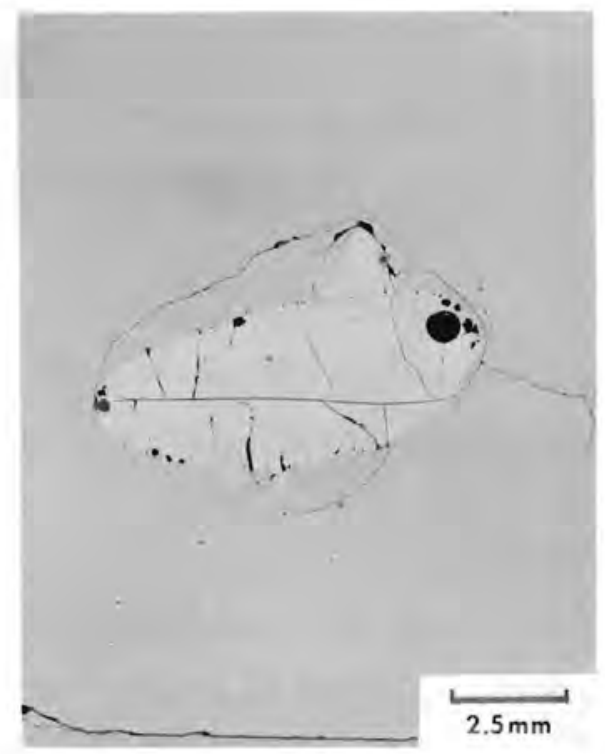

76-68 BEAD IN 1720 MATRIX $800^{\circ} \mathrm{C} \quad 10 \mathrm{MPa} 30$ Minutes

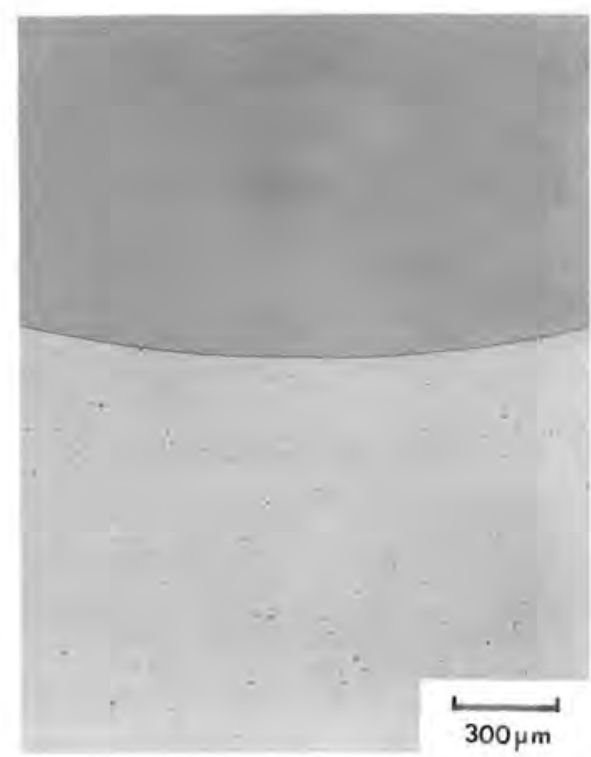

TDS-211 MARBLE IN 7570 MATRIX $500^{\circ} \mathrm{C} \quad 1200 \mathrm{MPa} \quad 10$ Seconds

FIGURE 3.B-5. Microstructure of Waste Glass Marble Reactions with Aluminosilicate Glass (Code 1720) and Lead Glass (Code 7570) Matrices

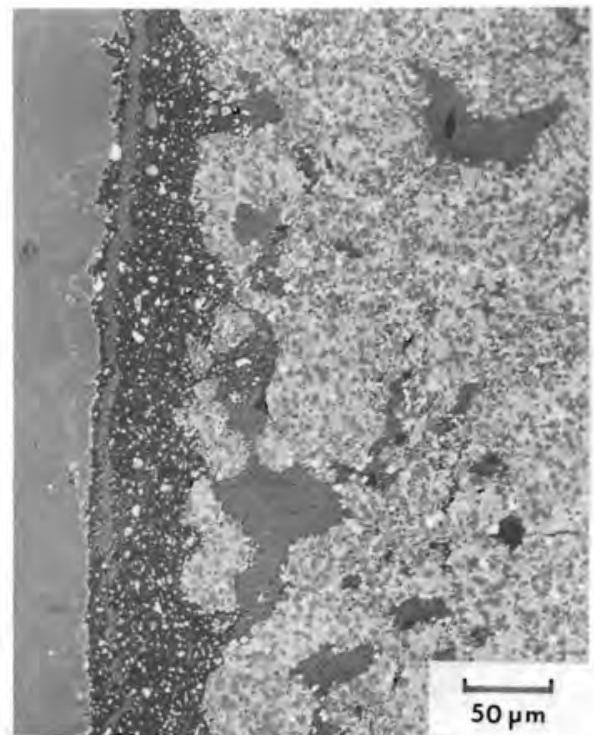

SINTERED SPC-4E IN 1720 MATRIX $800^{\circ} \mathrm{C} \quad 10 \mathrm{MPa} \quad 30$ Minutes

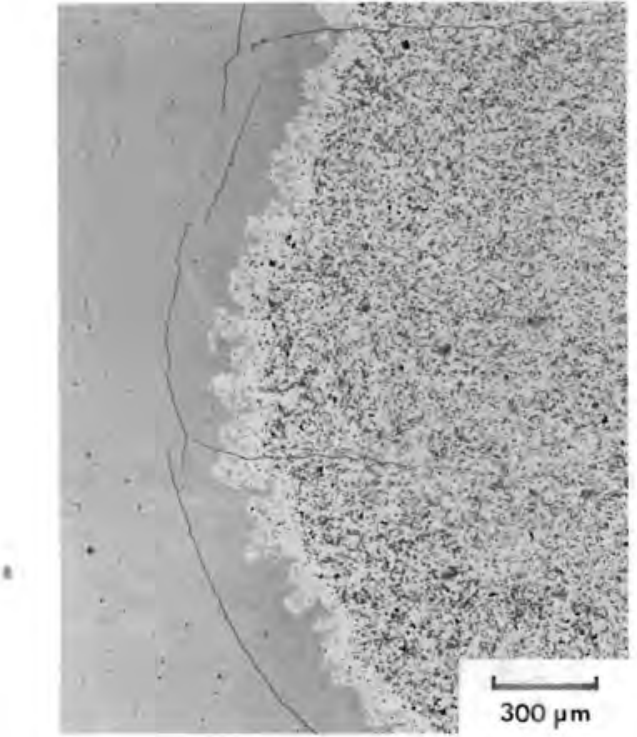

GREEN SPC-4E IN 1720 MATRIX $1000^{\circ} \mathrm{C} \quad 10 \mathrm{MPa} \quad 70$ Minutes

FIGURE 3.B-6. Microstructure of Supercalcine Pellet Reactions with Aluminosilicate Glass (Code 1720) and Lead Glass (Code 7570) Matrices 
Alumina - The key issue regarding the use of alumina as a ceramic matrix for nuclear waste encapsulation is the need for a non-porous matrix to minimize leaching of radioactive materials from the waste form. A density of about $92 \%$ of theoretical or higher is generally required to eliminate open porosity in sintered or hot pressed ceramic materials. Hot pressing temperatures considerably greater than the $1200^{\circ} \mathrm{C}$ upper limit assumed for this work are generally required to attain alumina densities in this range. However, densities up to $99 \%$ of theoretical have been achieved by vacuum hot pressing at $1200^{\circ} \mathrm{C}$ and $41.4 \mathrm{MPa}$ for five hours, using Linde $\mathrm{A}$ alumina $(0.3 \mu \mathrm{m})$ that had been treated in isopropyl alcohol, vacuum dried for 40 hours and handled in a moisture-free atmosphere until it was hot pressed (Rossi and Fulrath 1965).

Since it was believed that maintaining the alumina in a moisture-free condition in a hot cell would not be feasible, a hot pressing experiment was run at $1200^{\circ} \mathrm{C}$ and $34.5 \mathrm{MPa}$ for one hour in vacuum, using untreated Linde A alumina. The density achieved was $2.87 \mathrm{~g} / \mathrm{cm}^{3}(72.3 \%$ TD) as determined by immersion in isopropyl alcohol. Open porosity was measured at 25.3 volume percent. These results and other experience suggested that acceptable densities would not likely be achieved for hot pressed alumina powders in the temperature/pressure/time ranges judged to be practical for this work. Consequently no further hot pressing experiments with alumina powders were conducted.

Titania and Zirconia. Titania has been hot pressed to $100 \%$ theoretical density at $1200^{\circ} \mathrm{C}$ and $20.7 \mathrm{MPa}$, in argon, in a graphite die (Jackson and Palmer 1960). It has al so been pressed at $1070^{\circ} \mathrm{C}$ and $6.9 \mathrm{MPa}$ in air in an alumina die to $94.5 \%$ theoretical density (Spriggs et a1. 1963). In addition to these favorable hot pressing characteristics, $\mathrm{TiO}_{2}$ is attractive as a ceramic matrix for nuclear waste encapsulation because of its very high chemical stability. The development of Synroc and other titanate based ceramics as possible advanced waste forms are well recognized. Zirconia has been hot pressed to $91 \%$ theoretical density at $1200^{\circ} \mathrm{C}$ and $55.2 \mathrm{MPa}$ (Amato et al. 1967). While these results are borderline as to the possibility of producing a nonporous matrix at $1200^{\circ} \mathrm{C}$, information provided by a $\mathrm{ZrO}_{2}$ powder supplier suggests the possibility that high $\mathrm{ZrO}_{2}$ densities could be achieved in this temperature range. 
Titania and zirconia matrix development experiments performed in this work are summarized in Tables $3 . \mathrm{B}-5$ and 3.B-6. The $\mathrm{THO}_{2}$ used in this work was a highly sinterable reagent grade powder of $99.0 \% \mathrm{TiO}_{2}$ (minimum) ${ }^{(\mathrm{a})}$. Physical characteristics of the powder were not determined. A chemical grade $\mathrm{TiO}_{2}$ powder $(\mathrm{b})$ was used in run no. 21, Table 3.B-5. Chemical purity was unknown, but the powder was noticeably gray in color, in contrast to the pure white color of the reagent grade $\mathrm{TiO}_{2}$. The zirconia was a very reactive powder stabilized in the cubic phase with 8 weight percent 14.4 mole percent) or 12 weight percent $\left(6.6\right.$ mole percent) $\mathrm{Y}_{2} \mathrm{O}_{3}{ }^{(\mathrm{c})}$. It reportedly begins to sinter at about $900^{\circ} \mathrm{C}$ and cold pressed and sintered bodies of near theoretical density can be achieved at temperatures as $10 \mathrm{w}$ as $1450^{\circ} \mathrm{C}$. It has a crystallite size of 0.02-0.03 microns, an agglomerate size of $>90 \%$ less than 1 micron, and a BET surface area of 40-60 $\mathrm{m}^{2} / \mathrm{g}$. A typical composition of the $12 \mathrm{w} / \mathrm{O}_{2} \mathrm{O}_{3}-\mathrm{ZrO}_{2}$ is as follows:

$\begin{array}{lcll}\mathrm{ZrO}_{2} & 84.4 \text { wt.\% } & \mathrm{CaO} & 0.1 \\ \mathrm{Y}_{2} \mathrm{O}_{3} & 11.7 & \mathrm{MgO} & 0.1 \\ \mathrm{HfO}_{2} & 1.5 & \mathrm{Fe}_{2} \mathrm{O}_{3} & 0.01 \\ \mathrm{Al}_{2} \mathrm{O}_{3} & 0.2 & \mathrm{H}_{2} \mathrm{O}^{3} & 1.7 \\ & & \mathrm{Cl} & 0.3\end{array}$

As is evident from the comments in Tables 3.B-5 and 3.B-6, matrix cracking was a problem. The minor cracking of $\mathrm{TiO}_{2}$ matrices could probably be eliminated with additional development work. However the extensive cracking in $\mathrm{ZrO}_{2}$ matrices could prove to be extremely difficult, or even impossible, to eliminate.

The typical matrix cracking behavior can be seen in Figures 3.B-7 and 3.B-8. It is not likely that the cracking is simply due to differences in the thermal expansion coefficients of the SPC-4E pellets and the matrix

(a) Spectrum Chemical Mfg. Corp., Redondo Beach, CA.

(b) Titanox, Titanium Pigment Division, South Amboy, NJ.

(c) Zircar Products, Inc., Florida, NY. 
TABLE 3.B-5. Summary of Hot Pressed Titania Matrix Development

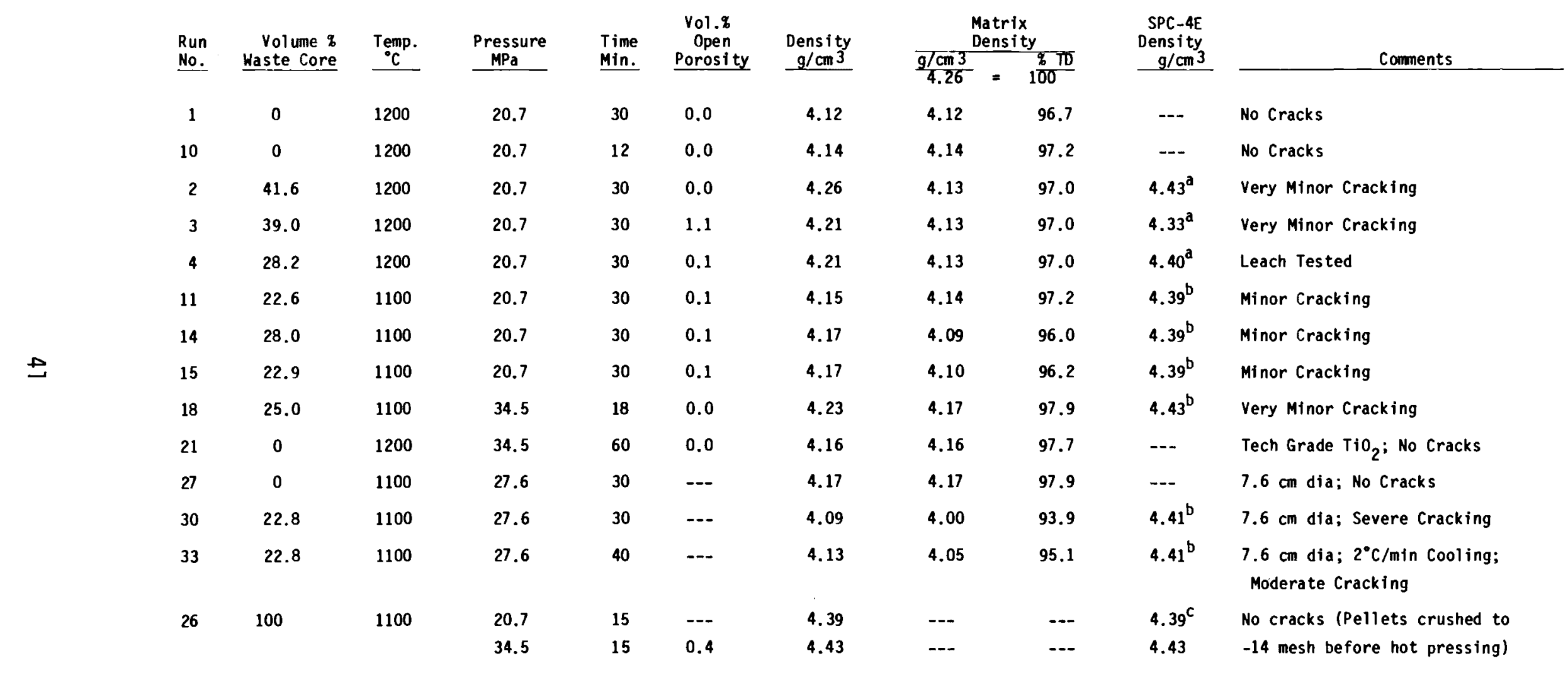

Notes: Disc pelletized SPC-4E presintered at $1200^{\circ} \mathrm{C}$ to $\sim 3.0 \mathrm{~g} / \mathrm{cm}^{3}(68 \% \mathrm{TD})$ used as waste core material.

$2.22 \mathrm{~cm}$ dianeter graphite die and $10^{\circ} \mathrm{C} / \mathrm{min}$ cooling rate used unless noted otherwise.

vacuum atmosphere $\left(\sim 10^{-4}\right.$ Torr $)$ used in all runs.

a Calculated assuming $\mathrm{TiO}_{2}$ density of $4.13 \mathrm{~g} / \mathrm{cm}^{3}$ (average from runs 1 and 10 )

b $\quad$ From run 26

c Calculated from ram movement measured on pressure increase from 20.7 to $34.5 \mathrm{MPa}$. 
TABLE 3.B-6. Summary of Hot Pressed Zirconia Matrix Development

\begin{tabular}{|c|c|c|c|c|c|c|c|c|c|c|}
\hline \multirow{2}{*}{$\begin{array}{l}\text { Run } \\
\text { No. }\end{array}$} & \multirow{2}{*}{$\begin{array}{r}\text { Volume } \% \\
\text { Waste Core }\end{array}$} & \multirow{2}{*}{$\begin{array}{c}\text { Temp. } \\
{ }^{\circ} \mathrm{C}\end{array}$} & \multirow{2}{*}{$\begin{array}{c}\text { Pressure } \\
\mathrm{MPa} \\
\end{array}$} & \multirow{2}{*}{$\begin{array}{l}\text { Time } \\
\text { Min. }\end{array}$} & \multirow{2}{*}{$\begin{array}{c}\text { Vol.\% } \\
\text { Open } \\
\text { Porosity } \\
\end{array}$} & \multirow{2}{*}{$\begin{array}{l}\text { Density } \\
\mathrm{g} / \mathrm{cm}^{3} \\
\end{array}$} & \multicolumn{2}{|c|}{$\begin{array}{l}\text { Matrix } \\
\text { Density }\end{array}$} & \multirow{2}{*}{$\begin{array}{r}S P C-4 E \\
\text { Density } \\
\mathrm{g} / \mathrm{cm}^{3} \\
\end{array}$} & \multirow[b]{2}{*}{ Comments } \\
\hline & & & & & & & $\mathrm{g} / \mathrm{cm} 3$ & कTD & & \\
\hline 5 & 0 & 1200 & 20.7 & 115 & 7.0 & 4.79 & 4.79 & 79.4 & -- & No Cracks \\
\hline 16 & 0 & 1200 & 34.5 & 60 & 1.4 & 5.37 & 5.37 & 89.1 & -- & No Cracks \\
\hline 6 & 29.1 & 1200 & 20.7 & 60 & 1.2 & 5.24 & $5.60^{\mathrm{a}}$ & 92.9 & 4.39 & Extensive Cracking \\
\hline 7 & 30.8 & 1200 & 20.7 & 60 & 1.8 & 5.20 & $5.57^{\mathrm{a}}$ & 92.4 & 4.39 & Leach Tested \\
\hline 8 & 31.1 & 1200 & 20.7 & 60 & 2.3 & 5.11 & $5.49^{\mathrm{a}}$ & 91.0 & 4.39 & Extensive Cracking \\
\hline 12 & 31.1 & 1200 & 20.7 & 60 & 2.0 & 5.25 & $5.65^{\mathrm{a}}$ & 93.7 & 4.39 & Extensive Cracking \\
\hline 13 & 32.7 & 1200 & 20.7 & 60 & 1.2 & 5.22 & $5.63^{\mathrm{a}}$ & 93.4 & 4.39 & Extensive Cracking \\
\hline 17 & 30.6 & 1200 & 34.5 & 30 & 0.6 & 5.21 & 5.57 & 92.4 & $4.43^{b}$ & Extensive Cracking \\
\hline 21 & 0 & 1200 & 34.5 & 60 & 29.2 & 4.03 & 4.03 &.-- & --- & $\begin{array}{l}12 \mathrm{w} / 0 \mathrm{Y}_{2} \mathrm{O}_{3} \text { stabilized } \mathrm{ZrO}_{2} \\
\text { No Cracks }\end{array}$ \\
\hline 22 & 31.2 & 1200 & 34.5 & 60 & 2.77 & 5.17 & 5.52 & $\cdots$ & $4.43^{b}$ & $\begin{array}{l}12 \mathrm{w} / 0 \mathrm{Y}_{2} \mathrm{O}_{3} \text { stabilized } \mathrm{ZrO}_{2} \\
\text { Extensive Cracking }\end{array}$ \\
\hline
\end{tabular}

Notes: $\quad 8 \mathrm{w} / \mathrm{O}_{2} \mathrm{O}_{3}$ stabilized $\mathrm{ZrO}_{2}$ matrix unless otherwise noted $\left(6.03 \mathrm{~g} / \mathrm{cm}^{3}\right.$ theo. density) Disc pelletized SPC $-4 E$ presintered at $1200^{\circ} \mathrm{C}$ used as waste core material

$2.22 \mathrm{~cm}$ dia. graphite die, vacuum atmosphere $\left(\sim 10^{-4}\right.$ Torr) and $10^{\circ} \mathrm{C} / \mathrm{min}$ cooling rate used in all runs

a Calculated assuming SPC-4E density of $4.39 \mathrm{~g} / \mathrm{cm}^{3}$ (from Table $3 . B-5$, runs 2-4) 
materials. SPC-4E has a thermal expansion coefficient of $9.35 \times 10^{-6} /{ }^{\circ} \mathrm{C}$, while that for $\mathrm{TiO}_{2}$ is $7.6 \times 10^{-6} /{ }^{\circ} \mathrm{C}$. The SPC-4E pellets shrink slightly more than the $\mathrm{TiO}_{2}$ matrix upon cooling from the hot pressing temperature, thus preventing buildup of stress in the $\mathrm{TiO}_{2}$. Microstructural examination of polished sections revealed that in several locations a perceptible gap existed at the pellet- $\mathrm{TiO}_{2}$ matrix interface.

The thermal expansion coefficient of the $\mathrm{ZrO}_{2}$ matrix is $10.2 \times 10^{-6} /{ }^{\circ} \mathrm{C}$, which is a very close match to that for SPC-4E. The slight difference could hardly be expected to cause the type or extent of cracking shown in Figure 3.B-8. The $\mathrm{ZrO}_{2}$ matrix cracking is probably due to the difference in densification behavior of the SPC-4E and the $\mathrm{ZrO}_{2}$ during hot pressing.

The densification behavior of SPC-4E, $\mathrm{TiO}_{2}$, and $8 \% \mathrm{Y}_{2} \mathrm{O}_{3}-\mathrm{ZrO}$ during hot pressing is detailed in Figure 3.B-9 and Table 3.B-7. Both SPC-4E and $\mathrm{TiO}_{2}$ begin to densify at about $850^{\circ} \mathrm{C}$, while the $\mathrm{Zr}{ }_{2}$ starts to densify at about $930^{\circ} \mathrm{C}$. Terminal density is reached at $1100^{\circ} \mathrm{C}$ for $\mathrm{SPC}-4 \mathrm{E}$ and $\mathrm{TiO}_{2}$, but the $\mathrm{ZrO}_{2}$ is still densifying at a linear rate after 110 minutes at $1200^{\circ} \mathrm{C}$. Al though the heating rate in run 5 with the $8 \% \mathrm{Y}_{2} \mathrm{O}_{3}-\mathrm{ZrO}{ }_{2}$ was $10^{\circ} \mathrm{C} / \mathrm{min}$, a factor of five greater than that used in runs 10 and 26 for $\mathrm{TiO}_{2}$ and SPC-4E, the lack of significant densification of the $8 \% \mathrm{Y}_{2} \mathrm{O}_{3}$ $\mathrm{ZrO}_{2}$ below $1100^{\circ} \mathrm{C}$ makes this difference in heating rates of relatively small importance.

The densification rate of the chemical grade $\mathrm{TiO}_{2}$ was not determined, as it was hot pressed in a run containing samples of three different materials. Densification rates of the individual materials could not be deduced from the overall densification rate. However, it is significant that the density of $97.7 \%$ of theoretical achieved in run 21 at $1200^{\circ} \mathrm{C}$ and $34.5 \mathrm{MPa}$ (5000 psi) for 60 minutes is comparable to that achieved for the higher purity reagent grade $\mathrm{TiO}_{2}$ under slightly different but similar conditions in run $18\left(97.9 \%\right.$ of theoretical at $1100^{\circ} \mathrm{C}, 34.5 \mathrm{MPa}, 18$ minutes).

The data of Table 3.B-7 emphasize the large difference in volume reduction that occurs for $\mathrm{SPC}-4 \mathrm{E}$ and $\mathrm{ZrO}_{2}$ at the same temperature. The volume reduction of $S P C-4 E$ is much greater than that of $\mathrm{ZrO}_{2}$ at each temperature. In the temperature range of 1000 to $1100^{\circ} \mathrm{C}$, the large volume decrease of the SPC-4E leaves the $\mathrm{ZrO}_{2}$ matrix essentially unsupported by the SPC-4E 

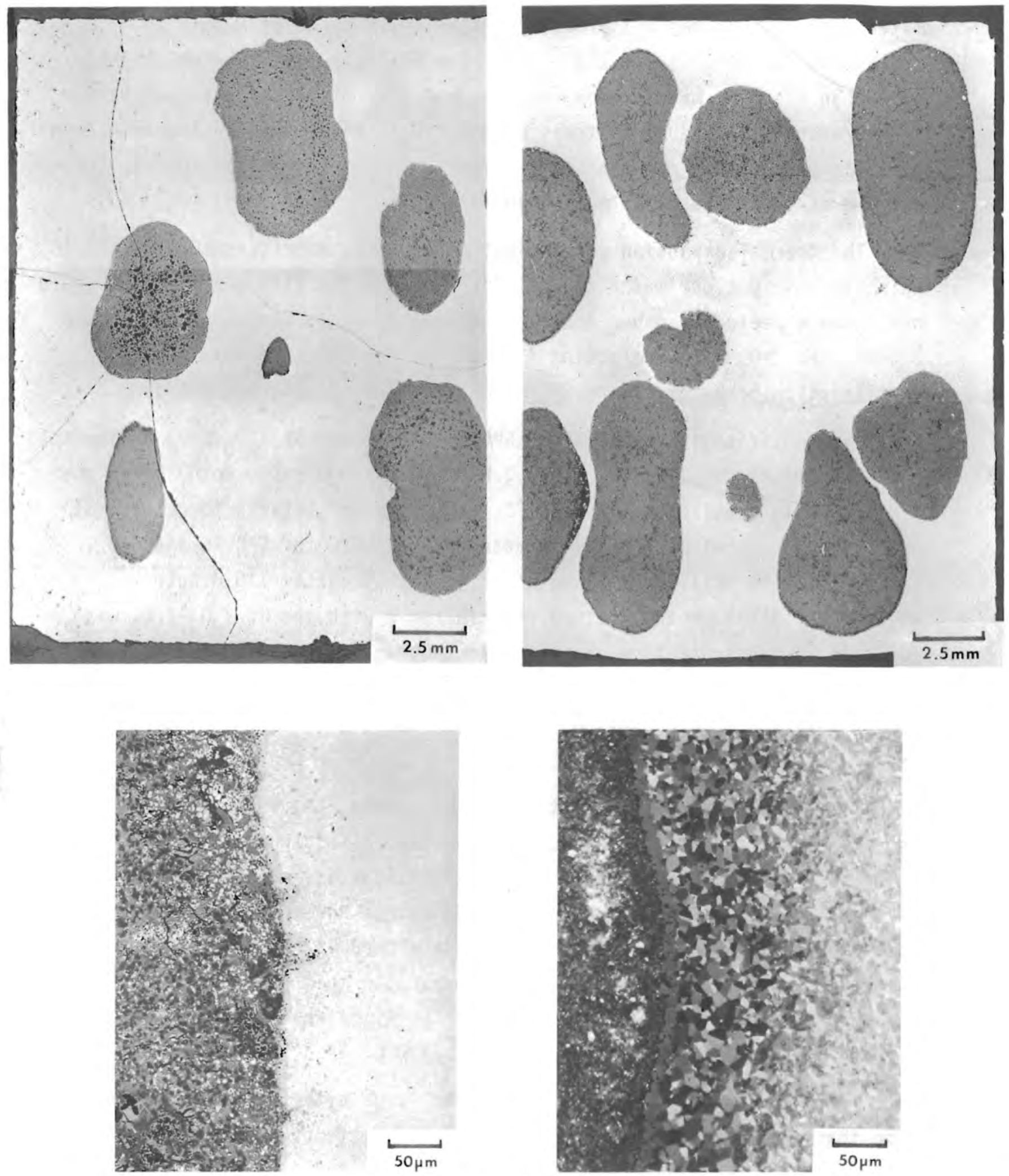

FIGURE 3.B-7. Microstructure of Hot Pressed SPC-4E Pellets in $\mathrm{TiO}_{2}$ (run no. 2 right and 11 on left) 

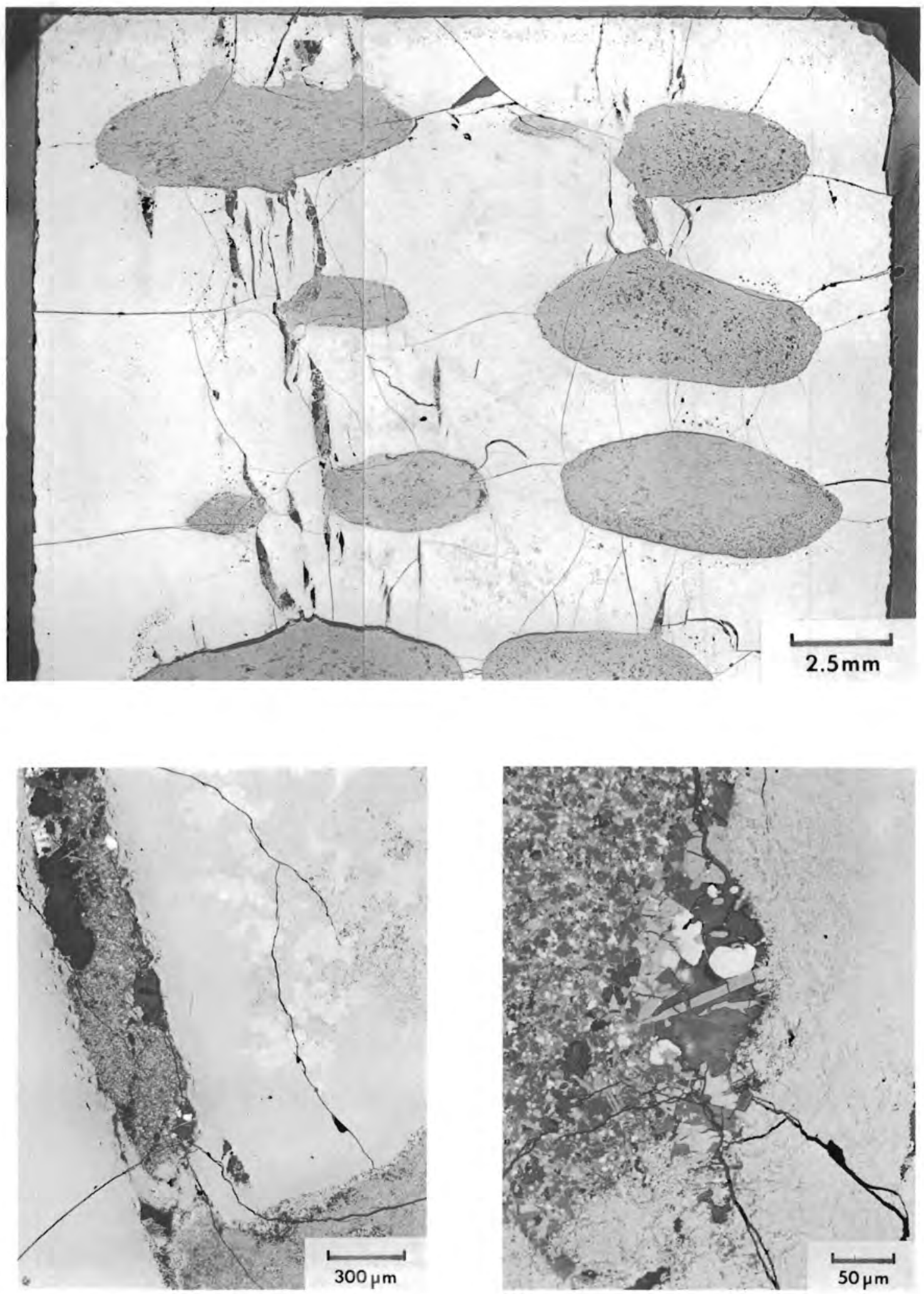

FIGURE 3.B-8. Microstructure of Hot Pressed SPC-4E Pellets in $8 \% \mathrm{Y}_{2} \mathrm{O}_{3}-\mathrm{ZrO}_{2}$ (run no. 6) 


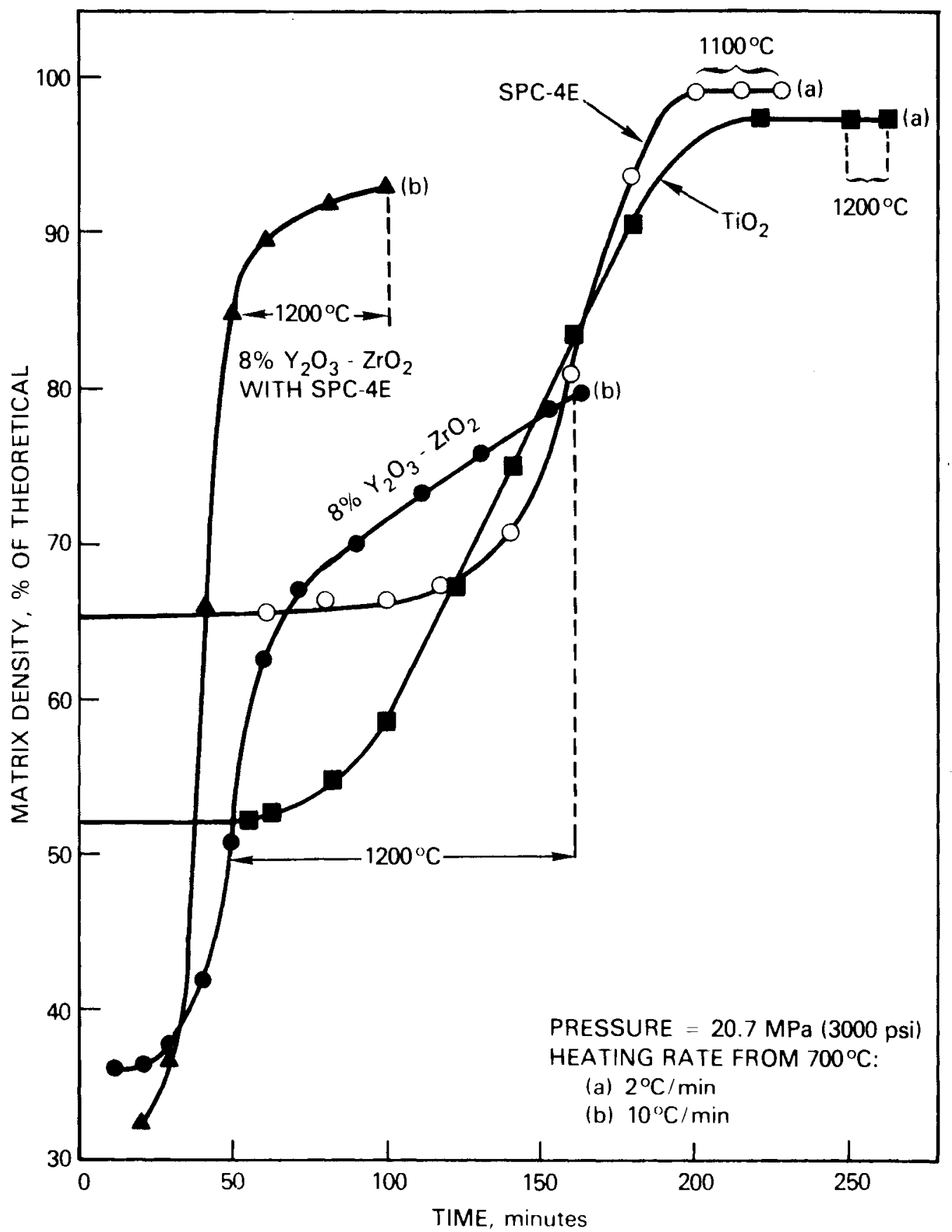

Figure 3.B-9. Hot Pressing Densification Behavior of Supercalcine and Ceramic Matrices

pellets. The axial cracks in Figure $3 . \mathrm{B}-8$ show that the $\mathrm{ZrO}_{2}$ matrix fractures by collapsing radially into the volume occupied by the rapidly shrinking pellets. The more plastic SPC-4E material is extruded into the cracks that open up in the matrix. This behavior was probably aggravated by the loading geometry used for the ceramic matrix hot pressing runs in the $2.22 \mathrm{~cm}$ dia. die. 
TABLE 3.B-7. Volume Reduction of Ceramic Matrices During Hot Pressing at 20.7 MPa

\begin{tabular}{|c|c|c|c|}
\hline \multirow[b]{2}{*}{$\begin{array}{l}\text { Temp. } \\
{ }_{0}^{\circ} \mathrm{C} \\
\end{array}$} & \multicolumn{3}{|c|}{ Cumulative } \\
\hline & $\overline{S P C}-4 E$ & $\frac{\text { duction }}{\mathrm{TiO}_{2}}$ & ${ }^{\mathrm{ne}} \mathrm{C} \mathrm{Y}_{2} \mathrm{O}_{3}-\mathrm{ZrO}_{2}$ \\
\hline 800 & 0 & 0 & 0 \\
\hline 860 & 1.2 & 5.5 & 0 \\
\hline 900 & 1.5 & 10.3 & 0 \\
\hline 940 & 2.7 & 22.4 & 1.6 \\
\hline 1000 & 14.0 & 34.3 & 4.8 \\
\hline 1060 & 30.1 & 42.5 & 9.3 \\
\hline 1100 & 34.1 & 45.9 & 13.5 \\
\hline
\end{tabular}

In the die loading procedure a layer of matrix powder was first placed in the die and compacted lightly by pushing down on the punch with hand pressure only. Four SPC-4E pellets were placed in the die and oriented at approximately $90^{\circ}$ intervals, leaving a gap of about one eighth inch between the pellets and the die wall. An additional layer of powder was added and compacted as before, followed by another layer of four pellets, making sure that each pellet was located about midway between two pellets in the lower layer. A total of five pellet layers was built up in this manner and topped with another layer of matrix powder. A similar loading technique was used for the $7.6 \mathrm{~cm}$ diameter die in runs 30 and 33 . This loading technique resulted in a central vertical column of matrix powder containing no pellets and an annular shell of pellet-free matrix powder near the die wall. It is believed that during the hot pressing period when the pellets are shrinking rapidly, the annular shell and the central area support most of the pressing load and collapse by brittle fracture into the void space provided by shrinking of the pellets, as already suggested. Possibly this effect could be minimized by using smaller pellets, a larger die, and random pellet orientation. 
From Table 3.B-7 the cumulative volume reduction of $\mathrm{TiO}_{2}$ is always greater than that of SPC-4E at the same temperature. This has the effect of ensuring that the pellets provide adequate support for the matrix, preventing the type of cracking that occurs with the $\mathrm{ZrO}_{2}$ matrix. The small amount of cracking that occurs with the $\mathrm{TiO}_{2}$ matrix could probably be reduced even further by optimizing pellet size, percent waste loading, loading techniques, and cooling cycle control.

The extent of interaction between SPC-4E pellets and the ceramic matrices can be seen in Figures $3 . \mathrm{B}-8$ and 3.B-9. For $1200^{\circ} \mathrm{C}$ hot pressing, the $\mathrm{TiO}_{2}$ matrix exhibits enhanced grain size in sporadic regions adjacent to the pellets. The affected regions are as thick as $\sim 1$ to $1.5 \mathrm{~mm}$. Titania grain sizes as large as $20 \mu \mathrm{m}$ are found near the pellet matrix interface, corresponding to a grain size enhancement factor of $\sim 5$. There is also evidence of a reaction product layer in both materials at their interface. At $1100^{\circ} \mathrm{C}$ hot pressing, neither enhanced matrix grain size nor reaction layers are obvious.

After this observation was made, the hot pressing temperature was reduced to $1100^{\circ} \mathrm{C}$ for subsequent $\mathrm{TiO}_{2} \mathrm{SPC}-4 \mathrm{E}$ hot pressing experiments to minimize reaction between the pellets and matrix. It is not known, however, that such a reaction would necessarily be disadvantageous for nuclear waste encapsulation. It is likely that some of the more volatile isotopes contained in the supercalcine pellets would form stable titanates with the $\mathrm{TiO}_{2}$, and the composite billet after hot pressing would have greater overall radioisotope retention properties than sintered supercalcine pellets alone. If so, it might be possible to take advantage of this effect by using a lower temperature for sintering the pellets before hot pressing, thus reducing loss of volatiles during sintering.

In the $1200^{\circ} \mathrm{C}$ hot pressed $8 \% \mathrm{Y}_{2} \mathrm{O}_{3}-\mathrm{ZrO}_{2}$ matrix samples there does not appear to be any change in matrix grain size due to proximity to the SPC-4E. There appears to be some growth of needle-like crystals in the matrix cracks adjacent to SPC-4E that seem to have been extruded into the cracks. These crystals appear to have condensed from vapor. The macrostructure shows evidence of shifting of relatively large segments of the matrix by a faulting process with subsequent extrusion of SPC-4E into the fault, resulting in offset steps in the pellet-matrix interface. 
There is a significant anomaly in the zirconia matrix density of Table 3.B-6. The $8 \% \mathrm{Y}_{2} \mathrm{O}_{3}-\mathrm{ZrO}_{2}$ was hot pressed at $1200^{\circ} \mathrm{C}$ to 79.4 and $89.1 \%$ theoretical at 20.7 and $34.5 \mathrm{MPa}$ respectively, in the absence of SPC-4E. When SPC-4E was present, matrix densities of $\sim 92 \%$ theoretical were obtained at both pressures. This large increase in matrix density suggested that a change was occurring in the relative amounts of cubic and monoclinic phases present. Stabilization of $\mathrm{ZrO}_{2}$ with $8 \% \mathrm{Y}_{2} \mathrm{O}_{3}$ is designed to retain approximately $15 \%$ monoclinic phase and $85 \%$ cubic at room temperature (Yavorsky 1962). The volume decrease due to transformation of monoclinic to tetragonal phase at high temperature compensates for the high thermal expansion of the cubic phase. The precise amount of $\mathrm{Y}_{2} \mathrm{O}_{3}$ required for stabilization reportedly depends upon the impurities present. However, $x$-ray diffraction analysis showed essentially the same crystalline phases present in uncracked hot pressed $8 \% \mathrm{Y}_{2} \mathrm{O}_{3}-\mathrm{ZrO}_{2}$ matrix samples and in cracked hot pressed samples of $8 \% \mathrm{Y}_{2} \mathrm{O}_{3}-\mathrm{ZrO}_{2}$ containing SPC-4E pellets. Thus, cracking cannot be attributed to a phase change in the matrix.

Another approach to determining if the $\mathrm{ZrO}_{2}$ matrix was cracking because of a phase change was to use a more fully stabilized powder. In runs 21 and $22,12 \% \mathrm{Y}_{2} \mathrm{O}_{3}-\mathrm{ZrO}_{2}$, with the same physical characteristics as the $8 \% \mathrm{Y}_{2} \mathrm{O}_{3}-\mathrm{ZrO}_{2}$, was hot pressed with and without $\mathrm{SPC}-4 \mathrm{E}$ pellets. Results were similar to those using $8 \% \mathrm{Y}_{2} \mathrm{O}_{3}-\mathrm{ZrO}_{2}$. No cracks occurred in the absence of SPC-4E and extensive cracking occurred when SPC-4E pellets were present. According to Yavorsky (1962) a composition of $15 \% \mathrm{Y}_{2} \mathrm{O}_{3}-\mathrm{ZrO}_{2}$ stabilizes the mixture as $100 \%$ cubic phase. It was concluded that the large reduction in the amount of monociinic phase present in $12 \% \mathrm{Y}_{2} \mathrm{O}_{3}-\mathrm{ZrO}_{2}$ compared to $8 \%$ $\mathrm{Y}_{2} \mathrm{O}_{3}-\mathrm{ZrO}_{2}$ should have caused a change in the cracking behavior if that cracking behavior was caused by phase changes occurring during the hot pressing or cooling cycle.

Other observations noted from the $12 \% \mathrm{Y}_{2} \mathrm{O}_{3}-\mathrm{ZrO}_{2}$ hot pressing experiments were:

- The $8 \% \mathrm{Y}_{2} \mathrm{O}_{3}-\mathrm{ZrO}_{2}$ has better hot pressing characteristics than $12 \%$ $\mathrm{Y}_{2} \mathrm{O}_{3}-\mathrm{ZrO}_{2}$. At $1200^{\circ} \mathrm{C}$ and $34.5 \mathrm{MPa}(5000 \mathrm{psi})$ for one hour the $12 \%$ 
$\mathrm{Y}_{2} \mathrm{O}_{3}-\mathrm{ZrO}_{2}$ was hot pressed to a density of $4.03 \mathrm{~g} / \mathrm{cm}^{3}(66.9 \% \mathrm{TD})$. The $8 \% \mathrm{Y}_{2} \mathrm{O}_{3}-\mathrm{ZrO}_{2}$ attained a density of $5.37 \mathrm{~g} / \mathrm{cm}^{3}(89.0 \% \mathrm{TD})$ under the same conditions.

- The effect discussed above wherein the presence of SPC-4E pellets causes an increase in the hot pressed $\mathrm{ZrO}_{2}$ matrix density is significantly greater for $12 \%$ than for $8 \% \mathrm{Y}_{2} \mathrm{O}_{3}$ in $\mathrm{ZrO}_{2}$. The increase in matrix density caused by SPC-4E was from 4.03 to $5.52 \mathrm{~g} / \mathrm{cm}^{3}$ for $12 \%$ $\mathrm{Y}_{2} \mathrm{O}_{3}-\mathrm{ZrO}_{2}$ and from 5.37 to $5.57 \mathrm{~g} / \mathrm{cm}^{3}$ for $8 \% \mathrm{Y}_{2} \mathrm{O}_{3}-\mathrm{ZrO}_{2}$.

The mechanism by which the presence of SPC-4E pellets enhances the hot pressing behavior of the $\mathrm{ZrO}_{2}$ matrix is unknown. A possibility is that volatile components of the SPC-4E become incorporated into the $\mathrm{Y}_{2} \mathrm{O}_{3}-\mathrm{ZrO} \mathrm{O}_{2}$ solid solution and alter its properties making it more plastic at hot pressing temperatures. Another possible explanation is that the SPC-4E causes a change in the oxygen potential of the sample which could affect the hot pressing behavior. In the $7.6 \mathrm{~cm}$ diameter $\mathrm{TiO}_{2}$ matrix sample (run no. 33 , cross section shown in Figure $3 . \mathrm{B}-1)$ the $\mathrm{TiO}_{2}$ matrix within a distance of approximately one centimeter from the surface is dark to light gray in color, gradually changing to off-white in the central portion. This color graduation is believed to be due to the presence of a reduced phase in the $\mathrm{TiO}_{2}$ as a result of reduction by carbon from the graphite die. The SPC-4E provides a sufficiently oxidizing atmosphere to overcome the reducing condition due to carbon. In the $7.6 \mathrm{~cm}$ diameter $\mathrm{TiO}_{2}$ sample that contained no SPC-4E pellets (run no. 27) a uniform gray coloration was present across the entire cross section of the hot pressed billet.

Based on these studies it is felt that neither $\mathrm{TiO}_{2}$ nor $\mathrm{ZrO}_{2}$ could be effectively used as matrix materials without considerable further development aimed at minimizing or eliminating matrix cracking. Leach test data should be included in the information used as a basis for optimizing supercalcine pellet size, volume percent waste loading, and hot pressing parameters. Minimal leach test data for $\mathrm{TiO}_{2}$ matrix run 4 and $\mathrm{ZrO}_{2}$ matrix run 7 , reported in Section 4, were not available until the hot pressing work was completed. The effect of the apparent reduction of $\mathrm{TiO}_{2}$ by the graphite die on leach test results should be included in any plans for additional studies of $\mathrm{TiO}_{2}$ as a matrix for nuclear waste. 
REFERENCES

Amato, I., et a1. 1967. J. Nucl. Mat., 22, p. 97-99.

American Society for Metals. 1980. Metals Handbook, 9th Edition, Vol. 3, Properties and Selection: StainTess Steels, Tool Materials and Special-Purpose Metals. Metals Park, Ohio.

Charlot, L. A. and R. E. Westerman. 1981. Corrosion Resistance of Cast Irons and Titanium Alloys as Reference Engineered Barriers for Use in Basalt Storage: A Literature Assessment. PNL-3569, Pacific Northwest Laboratory, Richland, WA.

Fullam, H. T. 1980. Use of Ceramic Materials in Waste-Package Systems for Geologic Disposal of Nuclear Wastes. PNL-3447, Pacific Northwest Laboratory, Richland, WA.

Gurwel1, W. E. 1981. A Survey of Matrix Materials for Solidified Radioactive High-Level Waste. PNL-3512, Pacific Northwest Laboratory, Richland, WA.

Hansen, John V. E. 1969. "Boron Carbide Body Armor," Metals Progress, $95(2)$, p. 111-114.

Jackson, J. S. and P. F. Palmer. 1960. Special Ceramics, Academic Press, New York. P. 319-322.

Rossi, R. C., J. D. Buch and R. M. Fulrath. 1970. J. Am. Cer. Soc., 53, P. 629-633.

Rossi, R. C., and R. M. Fulrath. 1965. J. Am. Cer. Soc. 48, p. 558-564.

Seybolt, A. U. and J. E. Burke. 1953. Procedures in Experimental Metallurgy. John Wiley and Sons, New York.

Spriggs, R. M., et al. 1963. Ceramic Bul1., 42, p. 477-479.

Thomas, A. G. and H. J. Jones. 1960. Powder Metallurgy, No. 6, p. 160-169.

Treat, R. L. et al. 1980. Prel iminary Evaluation of Alternative Waste Form Sol idification Processes, Volume 1: Identification of the Processes. PNL-3244, Pacific Northwest Laboratory, Rich1and, WA.

Yavorsky, P. J. 1962. Ceramic Age, 78:64-69. 


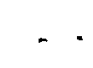


3.C. GRAPHITE MATRICES L.R. Bunnell and W.J. Gray

Introduction

Graphite has potential for use as a matrix and/or barrier material for the isolation of nuclear waste because of its low reaction rate with water (Gray 1980). This potential can only be realized, however, if the graphite is impermeable to water. Most graphites are permeable because of cracks and pores generated during fabrication due to carbonization of an organic binder. The graphite filler particles also contain cracks, but these probably don't contribute much to the permeability of a graphite body. Certainly, if all the graphite particles are separated from one another by binder, then any cracks within the particles would contribute nothing to the permeability. Only if there existed a chain of particles touching each other from one surface to another would cracks in the particles cause the body as a whole to be permeable. Even then, the contact between particles would have to be particularly fortuitous because the particles are extremely anisotropic and the cracks lie predominantly in one direction.

Because it is the binder phase that is most likely to be permeable, three methods occur as solutions to the permeability problem: (1) don't carbonize the organic binder or only partially carbonize it; (2) impregnate the graphite after it is fabricated; or (3) use an inorganic binder.

An uncarbonized binder would be subject to degradation by radiation from the nuclear waste. Decay heat from the waste would likely raise the temperature of the binder above its fabrication temperature of 150 to $300^{\circ} \mathrm{C}$, thereby at least partially carbonizing it. Therefore, the binder will probably have to be partially carbonized to begin with.

Impregnating an already fabricated graphite matrix with some type of organic resin would likely render it impermeable. However, the same comments made above would apply to the resin just as much as to a binder. The resin also would probably have to be at least partially carbonized.

Use of an inorganic binder seems to be defeating the original idea of using graphite as a matrix material because of its outstanding resistance to corrosion by water. The binder would have to be just as resistant as the 
graphite. The questions wich then arise are - Why not use pure binder material? What role does the graphite play? The only answer seems to be that it would act as an inexpensive filler and permit more scarce or valuable materials to be used as a binder than could otherwise be considered.

This report describes the fabrication and characterization, including permeability testing, of a variety of graphite-based materials. Information on encapsulation of glass marbles and some simulated waste pellets in various graphite-based matrices is also presented. It should be noted that much of the work reported here is al so applicable to barrier applications of graphite-based materials. Details more specifically related to the latter are reported el sewhere (Westerman 1981).

Candidate Binders: Development and Fabrication

Organic - The graphites with organic binders were all prepared by General Atomic Co. (G.A., San Diego). Initially, glass beads, simulated ceramic waste pellets, and marbles were encapsulated in graphite matrices using two different binders (Ashland A-240 petroleum pitch, a thermoplastic resin, and Monsanto Resinox 755, a thermosetting resin). These were chosen because of their previous history of use by the graphite industry. Results of this work have been described by Kaae and Bullock (1980).

Figure 3.C-1 shows a cross section of one of these early matrix rods. There is little, if any, bonding between the matrix and the glass beads, and some of the beads have fallen out. A few cracks emanating from the beads are evident even at low magnification. The many pores are typical of most graphites.

These early matrix rods were very permeable to water. In an effort to rectify this problem, the decision was made to concentrate initially on pure matrix materials and to test some alternative binders. All binder materials tested are listed in Table 3.C-1. The process used by General Atomic to produce matrices wherein the marbles or pellets are separated from one another by the matrix is shown in Figure 3.C-2. It is possible to produce a waste-free outer skin on the matrix rod by placing it in a larger mold with additional matrix materials around the outside and repeating the pressing and heat treatment steps. Pure matrix materials were produced for 

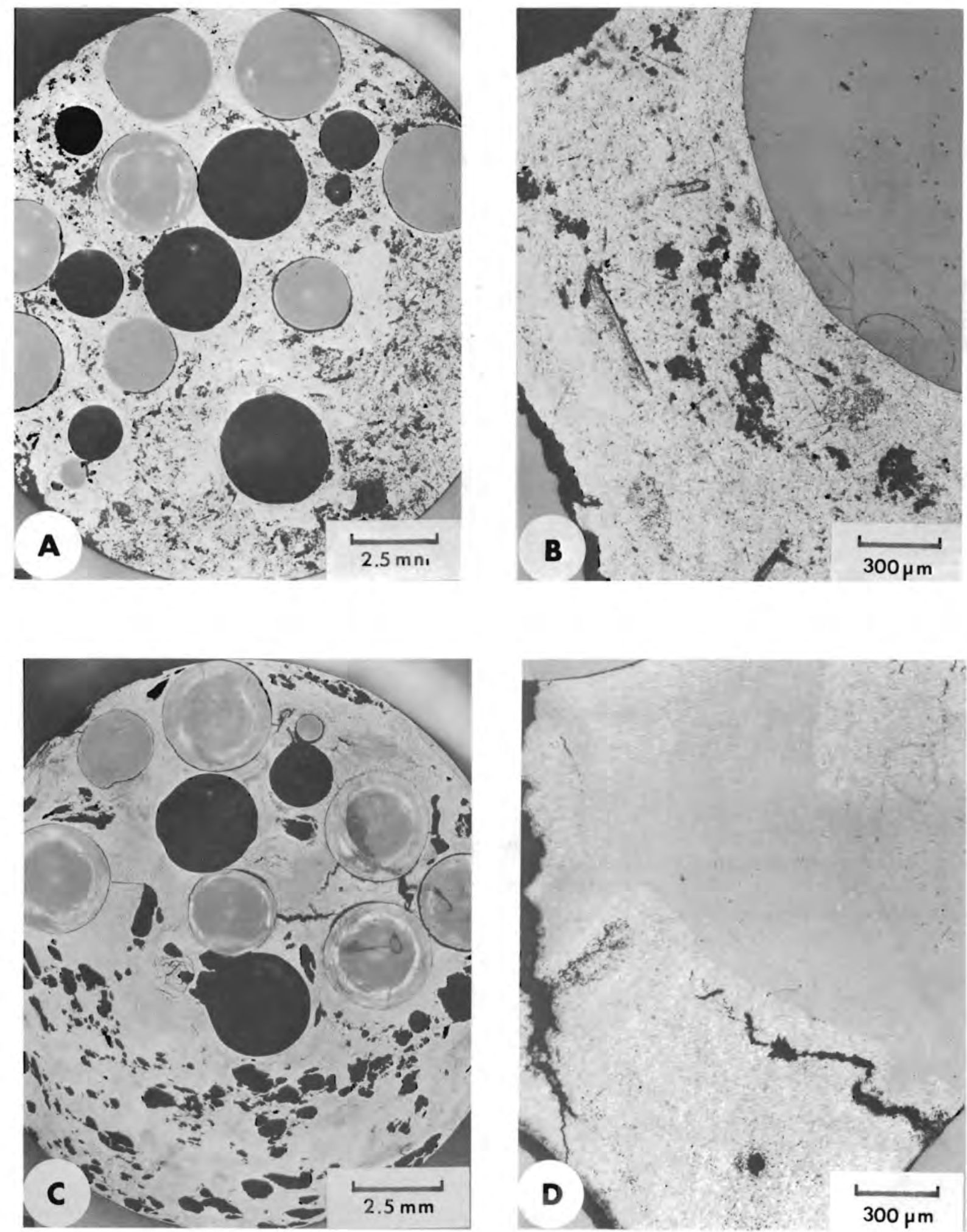

FIGURE 3.C-1. Graphite Matrix Rods with $3 \mathrm{~mm}$ dia. Glass Beads. $A$ and $B)$ : Ashland A-240 Pitch; C and D): Resinox 755 
TABLE 3.C-1. Permeability and Heat Treatment Results for Graphite Matrix Rods

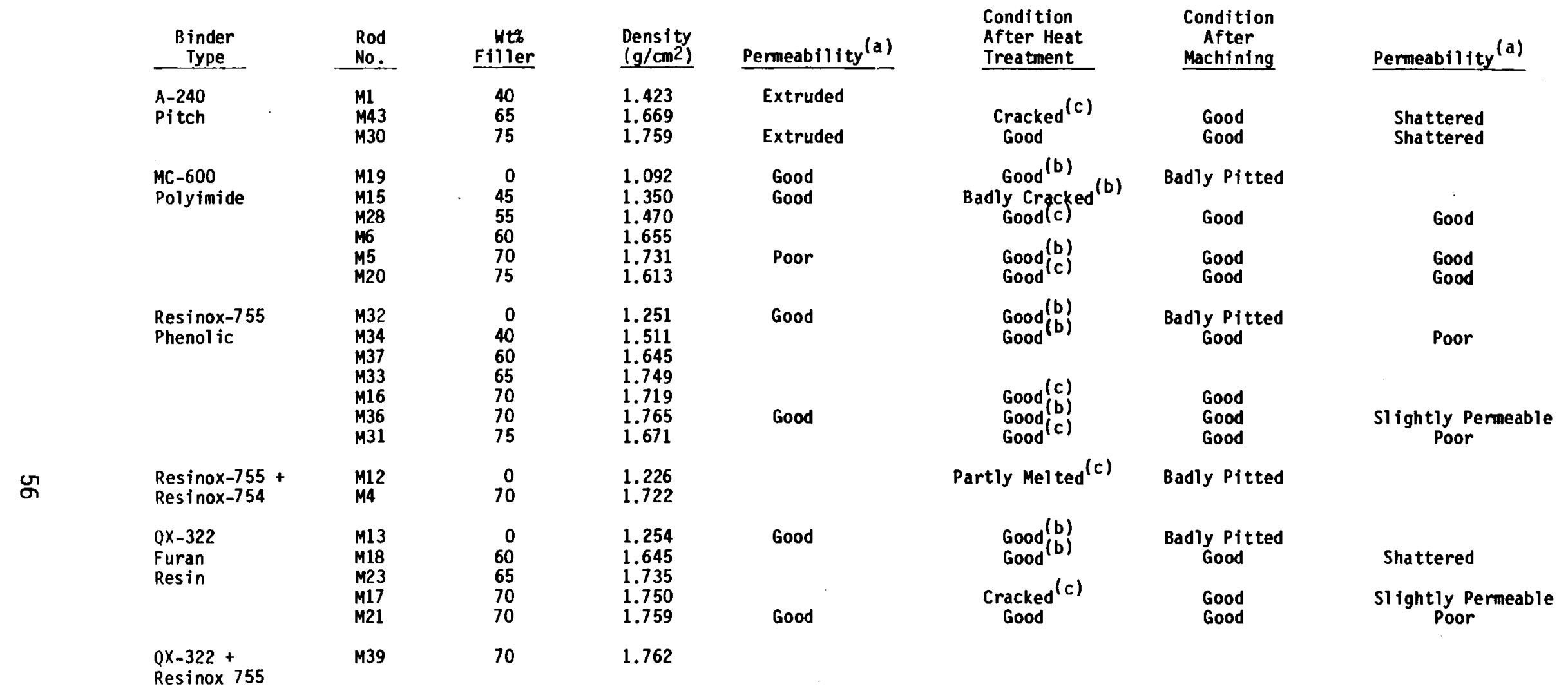

(a) Permeability tests were run at 1000 to 1500 psi for about 18 hours

al. "Good" means no water penetrated the specimens; flow rate $<10^{-9} \mathrm{ml} / \mathrm{s}$

a2. "Poor" means water did penetrate the specimen; flow rate $>10^{-6} \mathrm{ml} / \mathrm{s}$

a3. "Slightly permeable" indicates $10^{-9} \mathrm{ml} / \mathrm{s}<$ flow rate $<10^{-6} \mathrm{ml} / \mathrm{s}$

a4. Specimens containing A-240 pitch were too soft and were "extruded" through the sample holder

a5. Specimen "shattered" into small pieces (almost a powder) when pressure was applied.

(b) Rods were heated at $67^{\circ} / \mathrm{h}$ to $400^{\circ} \mathrm{C}$ and held for ten hours.

(c) Rods were heated at $50^{\circ} / \mathrm{h}$ to $100^{\circ} \mathrm{C}$, then at $3^{\circ} / \mathrm{h}$ to $400^{\circ} \mathrm{C}$ and held for six hours. 


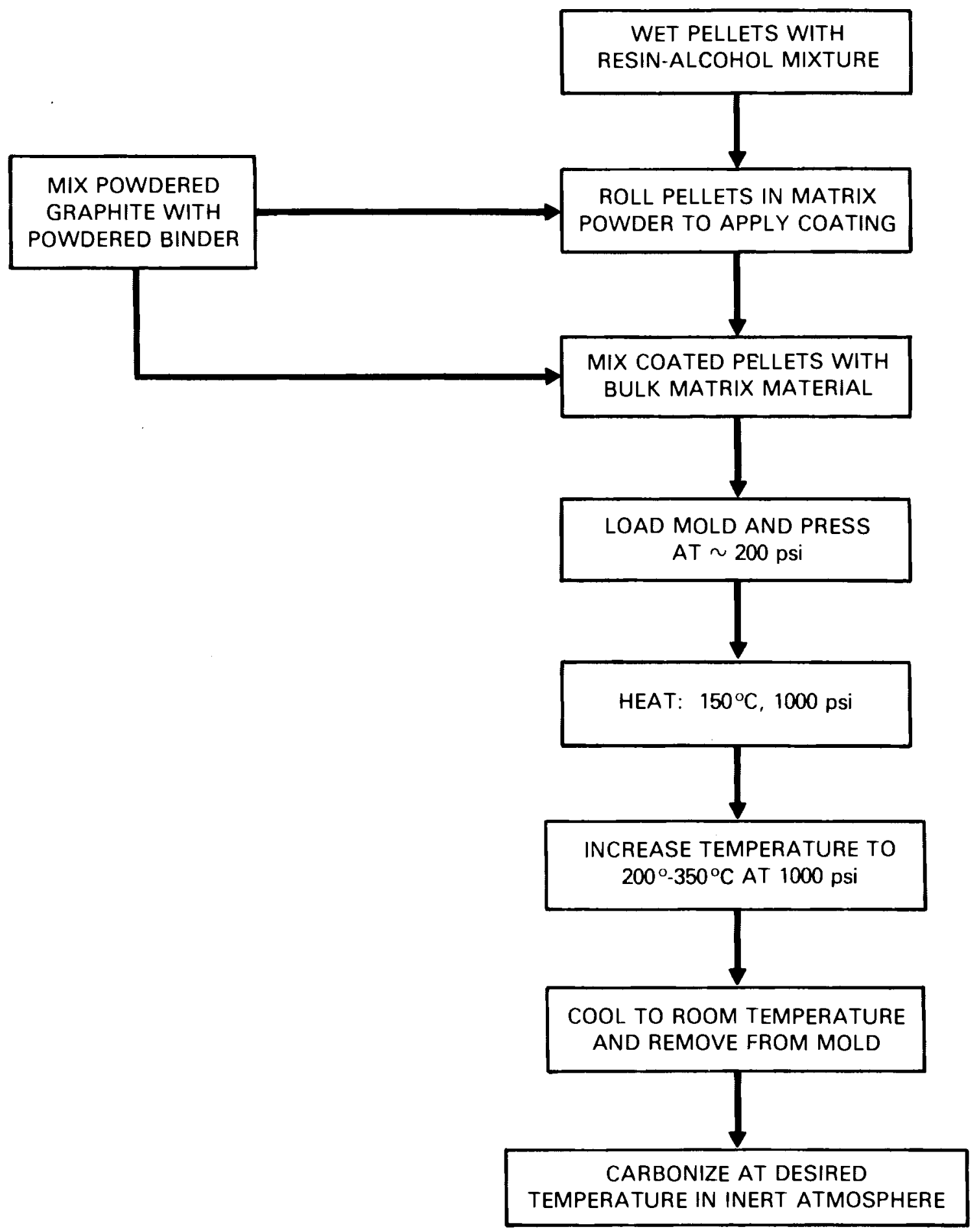

FIGURE 3.C-2. Flow Chart of Process Used by G.A. to Produce Beads Embedded in a Graphite Matrix 
testing using the process outlined in Figure 3.C-2, eliminating those steps associated with the marbles or pellets.

Besides work on matrix rods prepared by GA, some effort was made to produce an impermeable material by impregnating already fabricated graphite bodies with a phenolic resin. This and other details of the work with organic binders is described further in the section on permeability testing.

Inorganic - The number of inorganic materials that potentially could be melted, hot-pressed, or reacted in place to form a suitable matrix material is quite large. As mentioned earlier, the role of a graphite filler seems to be quite limited. Therefore, development studies on inorganic binders were limited to the testing of a material developed by NUKEM in West Germany in a patented process $(a)$ intended for use in low-level nuclear waste disposal. It is a graphite-based material that has NiS as a binder. NiS can be formed at $\sim 450^{\circ} \mathrm{C}$ but has a melting point of $800^{\circ} \mathrm{C}$. Its solubility product in water at $18^{\circ} \mathrm{C}$ is $1.4 \times 10^{-24}$, which is extremely low.

The process used at NUKEM to produce specimens of NiS-bonded graphite is as shown in Figure 3.C-3.

Some of the matrix material supplied by NUKEM was characterized by microscopic examination. Figure 3.C-4 shows optical micrographs of the material. Porosity is minimal and the (gray) graphite flakes are well surrounded and infiltrated by the (white) nickel sulfide phase. The SEM photographs show the graphite flake infiltration by the (white) NiS binder. The high contrast is due to the difference in secondary electron production rates. Figure 3.C-5 shows that cracks $<1 \mu \mathrm{m}$ across are filled by the NiS.

There are several possible stoichiometries for nickel sulfides, including $\mathrm{NiS}, \mathrm{Ni}_{3} \mathrm{~S}_{2}$, and $\mathrm{Ni}_{3} \mathrm{~S}_{4}$. X-ray diffraction indicated that $\mathrm{NiS}$ was the only phase present. Calculation made from the recipe supplied by NUKEM showed that the compact illustrated in the micrographs is rather binder-rich, at $35 \% \mathrm{NiS}, 65 \%$ graphite. The fact that the binder is the more soluble of the two would ordinarily indicate that it should be minimized for the sake of durability, but the material has probably been made this way to be stronger.

(a) Patent Number 2,917,437; Nov. 1980, F.R. Germany 


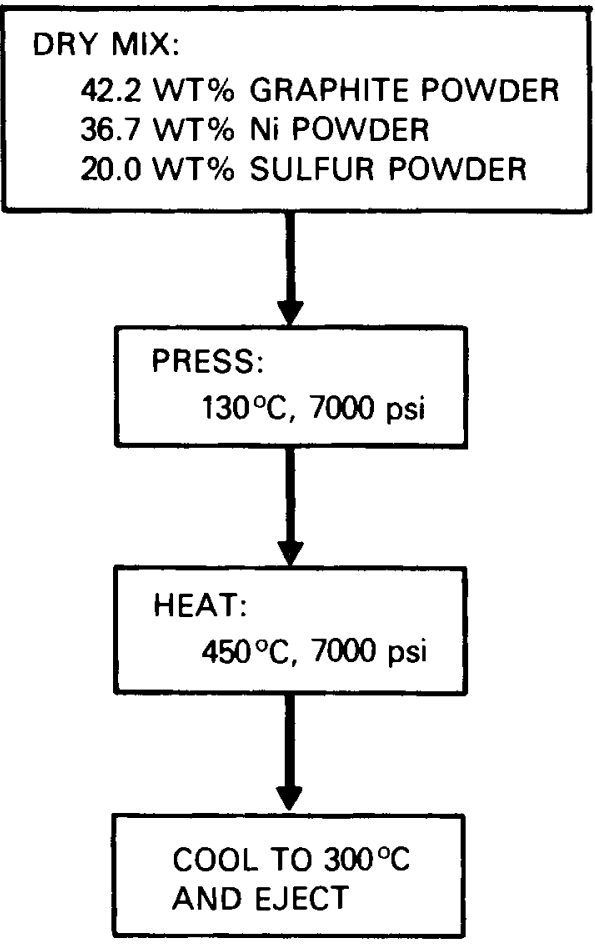

FIGURE 3.C-3. Flow Chart Used by NUKEM to Produce NiS-bonded Graphite

The process used by NUKEM was also followed at PNL in order to produce more samples for evaluation. The main difference was that the graphite dies used at PNL limited pressures to about 5000 psi. The resulting samples were sound and appeared similar to the NUKEM samples except that the nickel was not totally reacted. The nickel was purchased as -400 mesh $(37 \mu \mathrm{m})$ particles, which can be seen in Figure 3.C-6. Discussions with NUKEM revealed that they used $5 \mu \mathrm{m}$ powder. Therefore, the nickel powder was ball-milled overnight in water using $\mathrm{ZrO}_{2}$ grinding media and subsequently used to make further pressings. Figure 3.C-7 shows the resulting compact which indicates no unreacted $\mathrm{Ni}$ and is generally like the NUKEM material. Ability to readily produce this matrix material has thus been demonstrated. Figure 3.C-8 shows a PNL-made compact containing simulated waste glass marbles. There is no marble-to-marble contact, but the compact was laid up laboriously by hand. The glass-matrix bond shown in Figure 3.C-9 is very tight with no evidence of interaction. This compact was made with the coarser $\mathrm{Ni}$ powder, so unreacted $\mathrm{Ni}$ is in evidence. Both NUKEM- and PNL-produced compacts were evaluated for permeability as described in the later section on permeability testing. 


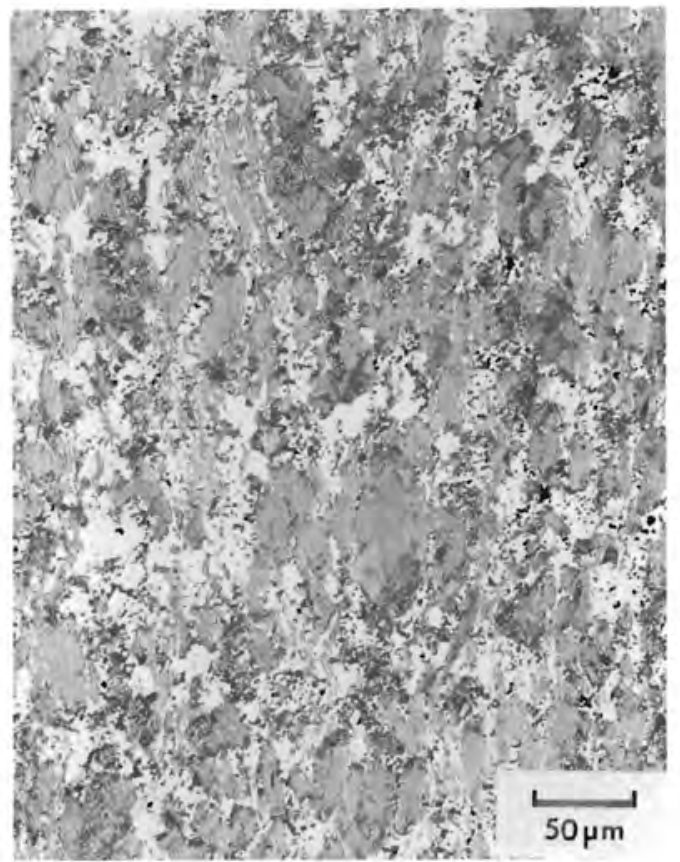

FIGURE 3.C-4. NiS-bonded Graphite Compact Produced by NUKEM

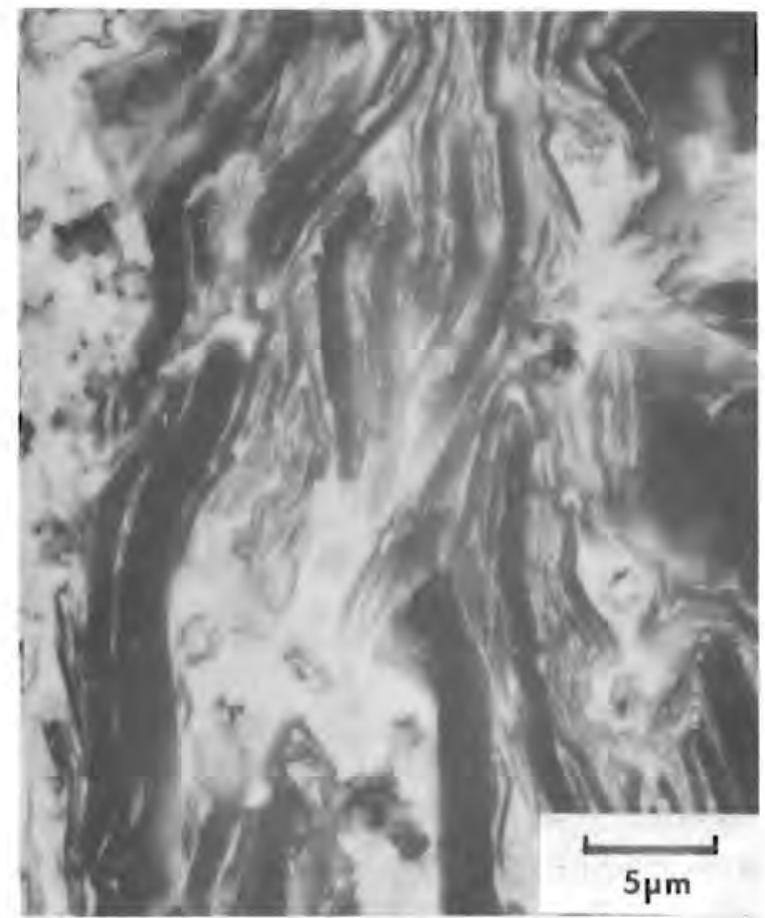

FIGURE 3.C-5. High-Magnification SEM Micrograph of the Center of Figure 3.C-4. Note Binder Infiltration into Tiny Cracks 


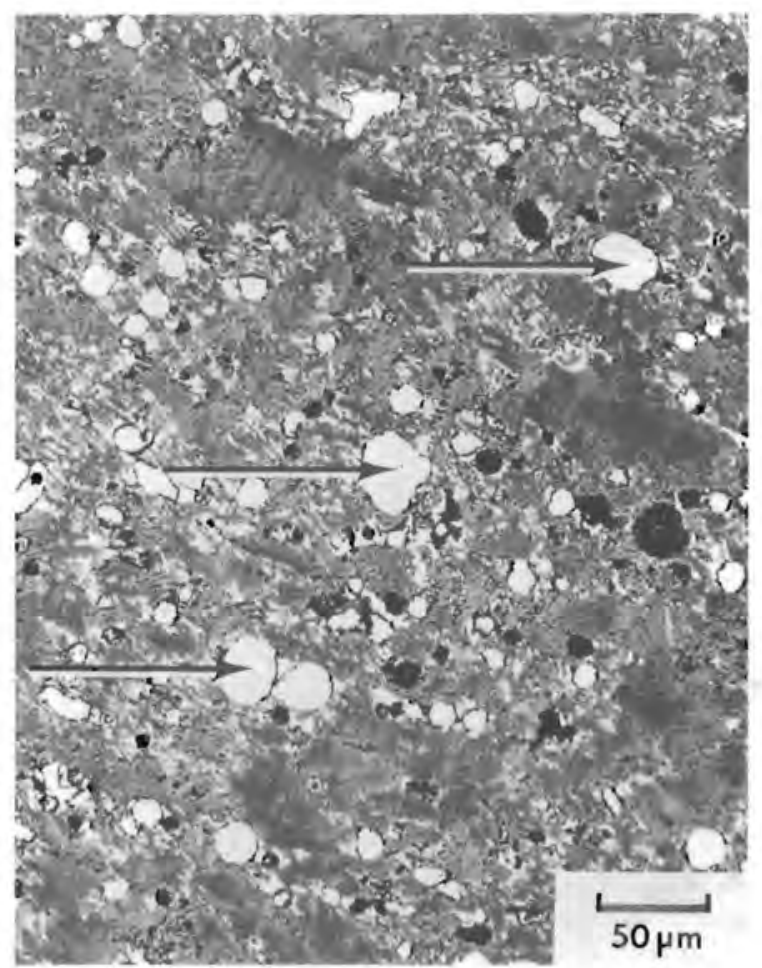

FIGURE 3.C-6. NiS-Bonded Graphite Sample Prepared at PNL (HP 19) Showing Several Unreacted Ni Particles (arrows)

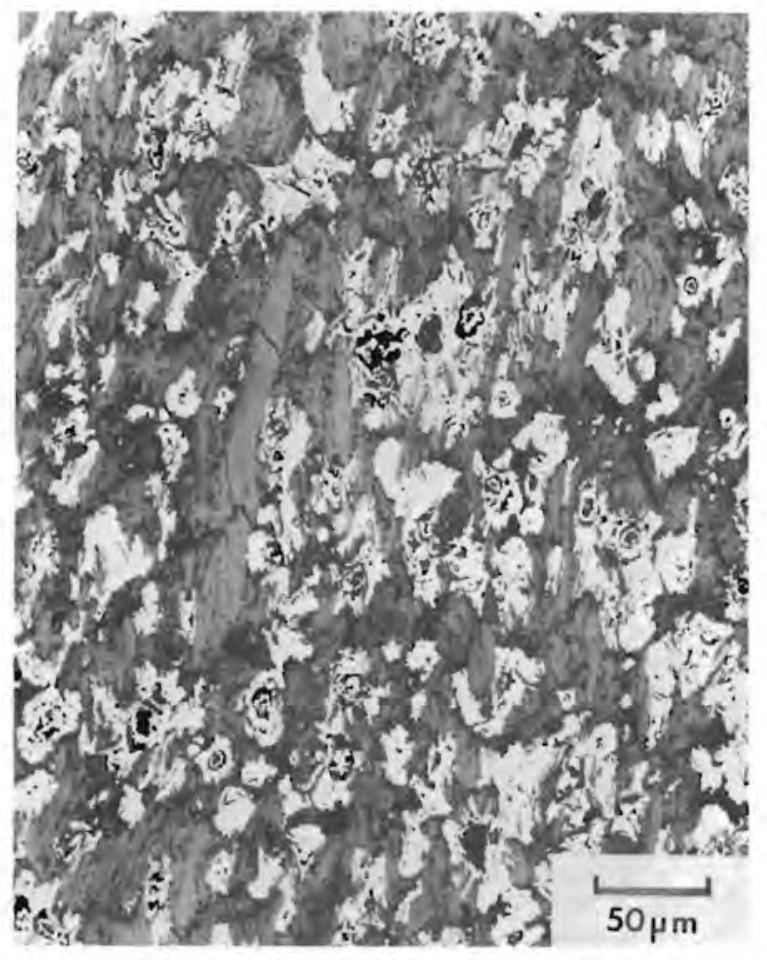

FIGURE 3.C-7. NiS-Bonded Graphite Using Milled Ni Powder 


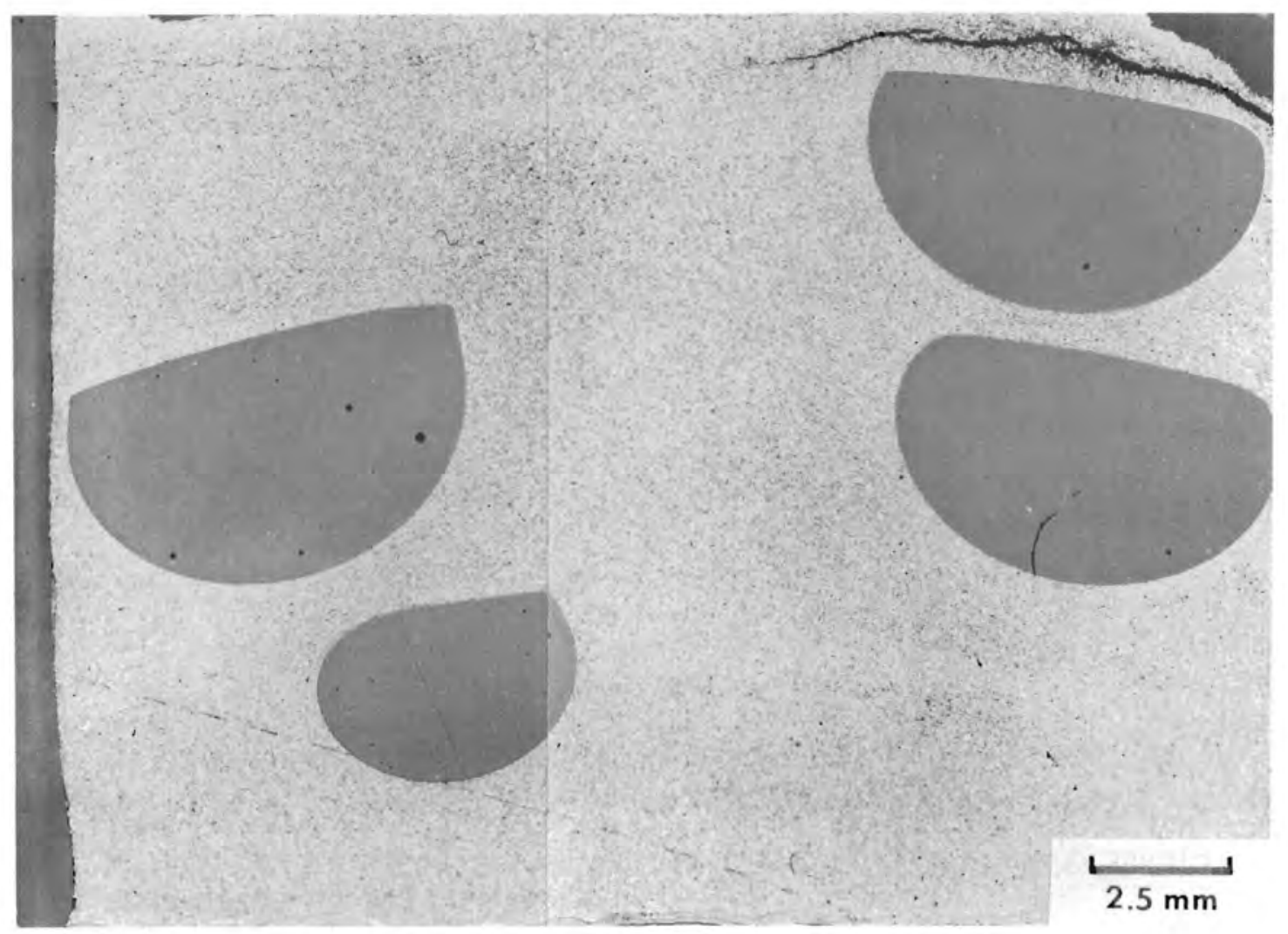

FIGURE 3.C-8. NiS-Bonded Graphite Compact Containing Simulated Waste Glass Marbles

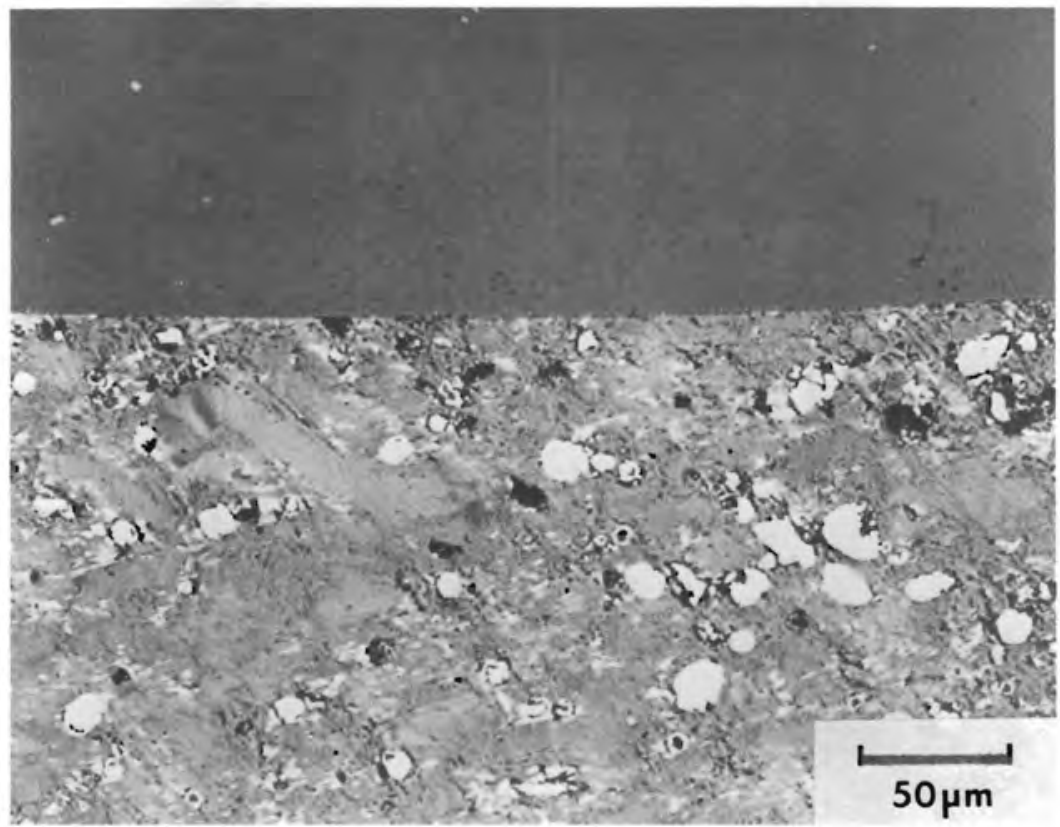

FIGURE 3.C-9. Micrograph of Figure 3.C-8 Showing Excellent Glass-to-Matrix Bond 
Permeability Apparatus

A schematic diagram of the water permeability apparatus is shown in Figure 3.C-7. It was originally designed for water pressures up to about 200 psi, but was later modified for pressures up to 1000 psi; some samples were tested at 1500 psi.

The sample size and geometry that have evolved to allow water pressures of 1000 psi to be used are as follows: 5/8 in. long and tapered from 0.625 in. diameter on one end to $0.515 \mathrm{in.} \mathrm{dia.} \mathrm{on} \mathrm{the} \mathrm{other} \mathrm{end.} \mathrm{Teflon} \mathrm{tape} \mathrm{is}$ wrapped around the sample to provide a seal. The use of 1000 psi was arbitrary, partially based on design of the sample geometry that evolved. Pressures of 1400 to 4200 psi could be readily justified based on the assumption that the waste repository would be $1000 \mathrm{~m}$ deep. A column of water that high would produce a pressure of 1400 psi while a column of rock with average density of $3 \mathrm{~g} / \mathrm{cm}^{3}$ would generate $4200 \mathrm{psi}$. Obviously, these pressures are also arbitrary. A few permeability tests were run at 1500 psi in order to approximate the lower of these pressures, but several samples broke. To allow the higher pressures to be used without breaking, the samples would have required a different sample design. Because the assumed repository depth of $1000 \mathrm{~m}$ is al so arbitrary, it was decided not to change the sample geometry and to continue testing at 1000 psi.

The moisture analyzer used in the apparatus of Figure 3.C-10 has a usable detection limit of about $1 \mathrm{ppm}$; the maximum moisture concentration it can measure is $1000 \mathrm{ppm}$. The analyzer requires a gas flow of 100 $\mathrm{ml} / \mathrm{min}$. Therefore, liquid water flow rates through the samples of about $10^{-9}$ to $10^{-6} \mathrm{ml} / \mathrm{s}$ can be measured. In practice, water flow rates through most graphite samples were either less than the minimum detection limit or more than the maximum detection limit. Very few fell within the measurable range. The tester, as used here, is thus a very sensitive go/no-go screening device.

Water permeability measurements are normally made on samples that have water in contact with both surfaces and whose pores are filled with water. However, a test arrangement of that nature would be unrealistic for waste applications where the inside surface is originally dry. Furthermore, measurement of very low permeabilities is difficult when water is in contact with both surfaces. Therefore, the lower surface was kept dry, and 


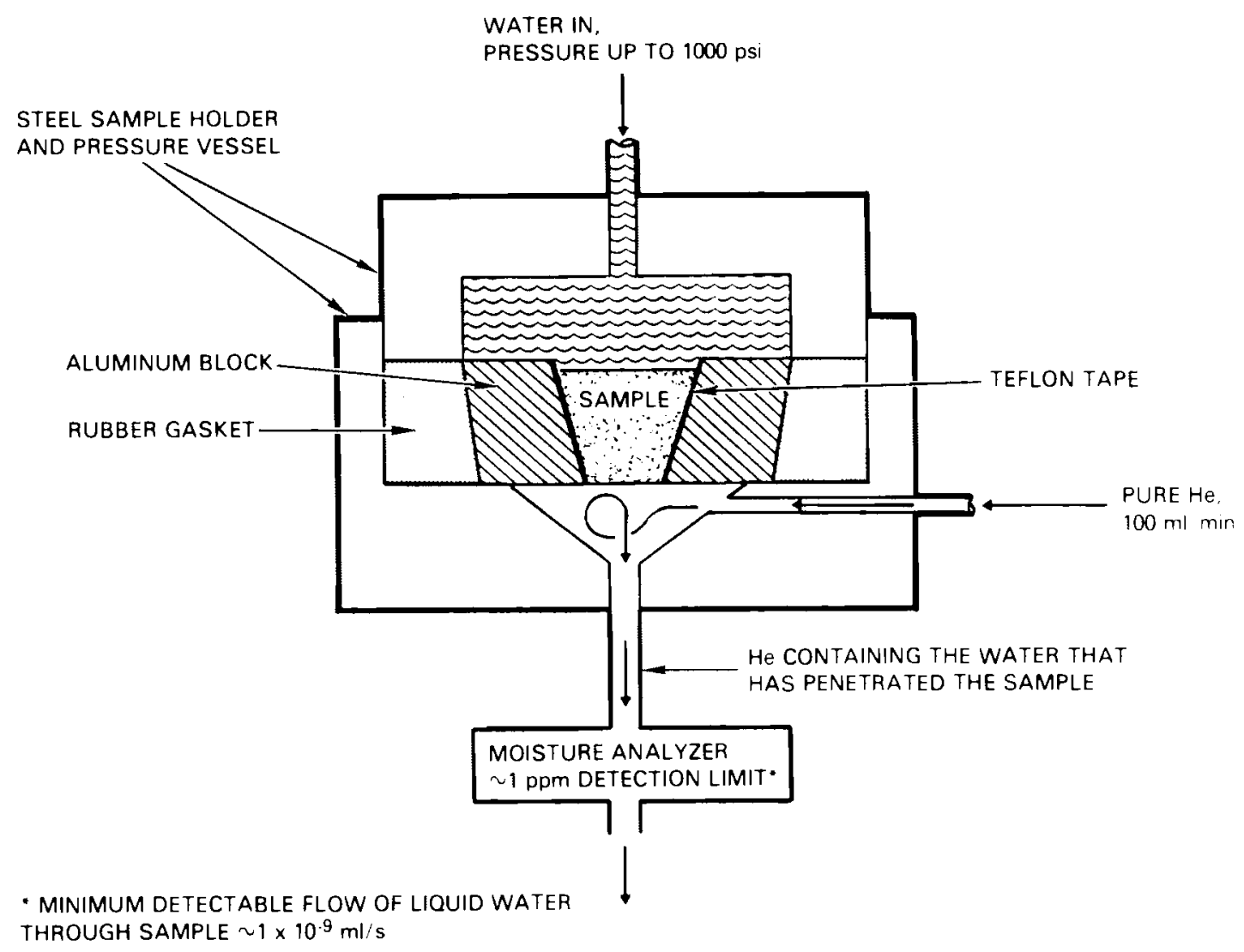

FIGURE 3.C-10. Schematic Diagram of Water Permeability Measuring Device

the apparatus was operated at temperatures in the range 40 to $50^{\circ} \mathrm{C}$ to ensure vaporization of any moisture that penetrated the sample.

With one surface dry, no liquid water will penetrate the sample unless the pressure is greater than that required to overcome the surface tension at the liquid-gas interface in the pores. This critical pressure is given by

$$
P=\frac{2 \gamma \cos \theta}{r}
$$

where $\gamma=$ surface tension of the liquid

$\theta=$ contact angle, assumed 0 for this case

$r=$ pore radius.

At $1000 \mathrm{psi}$ and $45^{\circ} \mathrm{C}$, water will penetrate pores of $200 \mathrm{~nm}$ radius and larger. 
Each of the permeability tests was run for about $20 \mathrm{~h}$. It was not deemed necessary to run them for longer times because, like porosimetry measurements, penetration into the pores should occur very quickly if the pressure is high enough; otherwise, penetration never occurs. In practice it took a few hours for water to pass through some of the samples; $8 \mathrm{~h}$ was the longest time. Otherwise no water penetrated in tests run as long as $22 \mathrm{~h}$. As a further test of the possibility that water might penetrate a sample after a much longer time, rod M20 was tested for seven days at 1000 psi during which time there was no water penetration. This same rod had previously been tested at 1000 psi for $21 \mathrm{~h}$ with no penetration.

\section{Permeability Results}

Organic Binders - Some of the original "matrix rods" produced by G.A. were left in the green state. That is, they were not heated above their initial forming temperature of 150 to $300^{\circ} \mathrm{C}$ and therefore were not carbonized. It was assumed that these green matrix rods, at least, would be impermeable to water. Whether they remained impermeable after large doses of gamma radiation, needed to be demonstrated. Two rods containing $3 \mathrm{~mm}$ dia. glass beads were selected for testing. The binder in one was thermoplastic pitch (A-240 petroleum pitch) and in the other was a thermosetting resin (Monsanto Resinox 755). Portions of both rods were placed in a ${ }^{60}$ Co radiation field of about $10 \mathrm{MR} / \mathrm{h}$ for gamma irradiation.

Water permeability measurements were made on a different portion of the two rods described above, using a water pressure of 180 psi. Both rods were more permeable than the maximum detection limit of the equipment. The other portion of the rods were, therefore, removed from the $\gamma$-radiation test after a dose of $1.4 \times 10^{10} \mathrm{R}$. They were essentially unchanged visually, but were also permeable, as expected from results for the unirradiated samples.

Permeability of the green matrix rods was very much a surprise and lead to the decision to abandon radiation testing and concentrate on preparing matrix rods that were at least initially impermeable. The first task was to determine whether a $100 \%$ matrix material could be produced which was impermeable. Therefore, a series of pure matrix rods were prepared by G.A. 
using a variety of organic binders and a wide range of binder-to-filler ratios. The filler in each case was finely powdered natural flake graphite. None of these were carbonized.

A list of the rods which were produced is given in Table 3.C-1. Several were permeability tested using water pressures of 1000 to 1500 psi, and most were found to be good, as is also shown in Table 3.C-1. Rod M5 was permeable (flow rate $>10^{-6} \mathrm{ml} / \mathrm{s}$ ) but this result apparently is not typical of the M5 material, based upon subsequent tests.

To achieve the high-temperature stability and radiation resistance necessary for use as a matrix material, some carbonization by high-temperature heat treatment will be required. It is not known how much heat treatment the rods can stand before they become permeable, however. To help answer this question, some of the rods were heated to $400^{\circ} \mathrm{C}$ in an argon atmosphere using two different heating schedules as shown in Table 3.C-1. Table 3.C-1 also shows that most of the rods looked good visually after the heat treatment.

Specimens were machined from the rods that still appeared sound after heat treatment. This caused the surfaces of some of the specimens to become highly cracked and pitted. Apparently the rods had a high density of very small cracks after heat treatment, and machining caused small pieces to fall out of the machined surface. It was originally thought that the slower heating rate would reduce this problem, but apparently it did not.

Permeability tests were run on samples that survived the heat treatment and machining. Several remained impermeable (flow rate $<10^{-9} \mathrm{ml} / \mathrm{s}$ ). Some samples shattered in the sample holder when a water pressure of 1500 psi was used. Subsequent tests were, therefore, run at 1000 psi.

Having demonstrated that pure matrix rods could be produced which remained impermeable even after heat treatment to $400^{\circ} \mathrm{C}$, a second attempt was made to produce impermeable matrix rods that contained $3 \mathrm{~mm}$ dia. glass beads. G.A. produced the rods listed in Table 3.C-2 using the process outlined in Figure 3.C-2. Some rods were left in the green state and others were heated to $400^{\circ} \mathrm{C}$. Permeability tests were performed on $5 / 8$ in. long sections of three of the rods. The rods were sectioned so that glass beads were 
exposed on both ends. All were found to be much more permeable than the maximum detection limit of the equipment even at pressures as low as about 50 psi. These rods, therefore, are no better than the original ones. Placing glass beads in the matrix causes it to become permeable.

TABLE 3.C-2. Graphite Matrix Rods Containing Glass Beads

\begin{tabular}{|c|c|c|c|}
\hline $\begin{array}{l}\text { Binder } \\
\text { Type }\end{array}$ & $\begin{array}{l}\text { Rod } \\
\mathrm{A} \rightarrow \mathrm{I}\end{array}$ & $\begin{array}{c}\text { Heat Treatment } \\
\text { Temp. }\left({ }^{\circ} \mathrm{C}\right) \\
\end{array}$ & $\begin{array}{c}\text { Permeability } \\
\text { Test }\end{array}$ \\
\hline $\begin{array}{l}\text { Resinox } 755 \\
\text { Phenolic }\end{array}$ & $\begin{array}{l}J 4 \\
J 2 \\
J 3 \\
j 5\end{array}$ & $\begin{array}{c}\text { Green } \\
400 \\
400 \\
400\end{array}$ & $\begin{array}{l}\text { Yes } \\
\text { No } \\
\text { No } \\
\text { No }\end{array}$ \\
\hline $\begin{array}{l}\text { MC }-600 \\
\text { Polyimide }\end{array}$ & $\begin{array}{l}\mathrm{J} 7 \\
\mathrm{j} 6\end{array}$ & $\begin{array}{c}\text { Green } \\
400\end{array}$ & $\begin{array}{l}\text { Yes } \\
\text { Yes }\end{array}$ \\
\hline
\end{tabular}

The micrographs of the original matrix rods in Figure 3.C-1 show that the glass beads are not bonded to the matrix. If the beads were in contact with one another this would provide a path for the water. However, as outlined in Figure 3.C-2, the beads are individually coated before they are placed in the matrix so that they do not touch one another. The explanation, therefore, has to be that the beads are linked by a network of cracks. Some cracks are visible in the micrographs. Apparently even the small amount of shrinkage that takes place during the initial curing of the matrix is prevented by the beads and the matrix, therefore, cracks.

Impregnated Graphites - Besides studies on matrix rods prepared by G.A., some effort was made to produce an impermeable material by impregnating graphite bodies with an organic resin. A sample of ATJ graphite 0.560 in. thick was vacuum impregnated with polyfurfuryl alcohol and heat treated at $140^{\circ} \mathrm{C}$ for $60 \mathrm{~h}$ to cure the resin. This sample was impermeable as determined by a test performed at a water pressure of $180 \mathrm{psi}$. After $0.060 \mathrm{in}$. was machined off both the top and bottom surfaces, the sample was still impermeable. When an additional $0.060 \mathrm{in}$. was machined off the top and bottom surfaces, the sample was rendered permeable. 
Permeability tests were also run on a graphite-based material called KARBATE ${ }^{3}$. This is a graphite body that is subsequently impregnated with a phenol ic resin to make it impermeable. Samples tested at PNL, which were machined from a larger piece, were found to be permeable.

Results obtained on KARBATE and on the ATJ graphite impregnated at PNL are apparently related. They both were permeable after the originally impregnated surface was removed. This occurs because only those pores which are open to the surface are filled with resin. When the original surface is removed, pores which were not originally open to the surface are exposed and the sample becomes permeable.

These results suggest that waste pellets or marbles could be encapsulated in a graphite matrix which is then impregnated to make it impermeable. It would be a good waste form as long as the surface was not disturbed. However, cracks or chips deeper than about $1 / 16$ in. would in principle, allow water to penetrate the waste form. Therefore, this approach was not continued.

Inorganic Binders - Nickel sulfide bonded graphite made by NUKEM was not penetrated by water at $1000 \mathrm{psi}$ for $22 \mathrm{~h}$. The first NiS-Bonded graphite made at PNL was penetrated almost immediately even at water pressures as low as 300 psi. This was the material that contained unreacted Ni particles. Material prepared later using finer $\mathrm{Ni}$ powder and exhibiting no unreacted $\mathrm{Ni}$ was also found to be permeable. That is, water penetration (>1000 ppm) was observed after about $1 \mathrm{~h}$ at $500 \mathrm{psi}$. It appears that the PNL-produced material using milled $\mathrm{Ni}$ powder, while metallographically similar to the NUKEM specimens, is not quite as impermeable. The NiS has probably not penetrated the filler particles to the high degree shown in Figure 3.C-5. The difference may be pressure-related, or perhaps some other minor processing variable is responsible. Interest in this type of matrix would enable a further degree of process tuning to produce material that is truly equivalent.

- Registered trade name of Union Carbide Corporation. 


\section{Leach Results: Graphitic Matrix Materials}

Organic Binders - The leach rates of graphite and other carbonaceous materials have been measured and found to be two to three orders of magnitude lower than that of $\mathrm{Al}_{2} \mathrm{O}_{3}$ which is the next best material studied. Details of these results have been published by Gray (1981) and by Fullam (1980). Actually, Fullam reported graphite to be only marginally better than $\mathrm{Al}_{2} \mathrm{O}_{3}$, but he computed leach rates on the basis of geometric surface areas which were smaller than the BET surface area of his graphite by a factor of more than 2000. The BET and geometric surface areas of his $\mathrm{Al}_{2} \mathrm{O}_{3}$ samples, on the other hand, were essentially the same.

Leach tests were also performed on two matrix rods that were prepared by G.A. and contained $\mathrm{NaCl}$ pellets. These tests would more properly be described as a type of permeability experiment because a layer of salt-free material entirely surrounded each rod. Thus, the tests were a measure of the ability of water to penetrate the matrix, dissolve the salt, and return to the leachate solution.

Resinox 755 phenolic was used as the binder in both $\mathrm{NaCl}$ matrix rods. One was left in the green state and the other was heat treated to $400^{\circ} \mathrm{C}$. The green rod appeared sound visually, but the heat treated rod had very obvious surface cracks near one end. That end was cut off and capped with a titanium cup so that the $\mathrm{NaCl}$ would not be directly exposed to water in the leach tests. Dow Corning Silicone Rubber Sealant was used to glue the cap in place. The same type of silicone rubber was used as a gasket material in the permeability tests described earlier and it proved, in those tests, to be impermeable to liquid water.

Both $\mathrm{NaCl}$ matrix rods were leached for 14 days at $90^{\circ} \mathrm{C}$ in deionized water, and the leachate solutions were analyzed for $\mathrm{Na}$ using Induction Coupled Plasma Spectroscopy. No Na above the detection 1 imit of $0.01 \mathrm{ppm}$ was found in the solution from the green rod, but that from the heat treated rod contained $168 \mathrm{ppm} \mathrm{Na}$. It seems likely that water penetrated the rod through small cracks that were not noticed upon visual inspection al though it is possible that the silicon rubber did not form a perfect seal. The good results in the green rod must be attributed to the salt-free layer of matrix material on the outside of the rod, because there is no reason to 
believe that the main body of the rod should be noticeably less permeable than the rods that contained glass beads. The latter, as described earlier, were all found to be permeable.

Inorganic Binders - The leach resistance of the graphite matrix material made according to Figure 3.C-3 by NUKEM, was determined in a series of leach tests. Samples containing no waste products were exposed to distilled water at $90^{\circ} \mathrm{C}$ and atmospheric pressure, while samples containing 30 wt\% SPC-2 were tested at $150^{\circ}, 200^{\circ}$ and $250^{\circ} \mathrm{C}$ in sealed metal bombs. The surface area/water volume ratio was kept at $10 \mathrm{~m}^{-1}$, and solutions were analyzed for $\mathrm{Ni}$ by induction-coupled plasma and atomic absorption spectroscopy. Data are reported in Table 3.C-3.

TABLE 3.C-3. Leach Test Results, NUKEM NiS-Bonded Graphite

\begin{tabular}{ccccc} 
Temperature, ${ }^{\circ} \mathrm{C}$ & Time, Days & Ni Concentration, $\mathrm{ppm}$ & $\mathrm{pH}$ \\
\cline { 2 - 3 } 9 & 1 & 7.3 & NA \\
90 & 3 & 14 & 7.0 \\
90 & 12 & 21 & 6.9 \\
90 & 28 & 37 & NA \\
$\star 150$ & 28 & 0.6 & 11.1 \\
$\star 200$ & 28 & 0.5 & 11.1 \\
$\star 250$ & 28 & 0.5 & 9.9
\end{tabular}

\footnotetext{
NA = Not Available

* = Samples contain 30 wt\% SPC -2
}

The unusual temperature dependence of the nickel concentration in solution may be explained by the fact that all of the specimens leached above $90^{\circ} \mathrm{C}$ showed a greenish film which apparently contained nickel. Unless the film formed during cooling it was more stable than nickel in solution.

In addition, NUKEM al so prepared specimens of their matrix material containing powdered supercalcine SPC-4P. Leach testing was also performed on this material at $90^{\circ} \mathrm{C}$. The results indicate a substantial leaching of the supercalcine constituents, but the compacts were prepared by admixing $30 \%$ of the supercalcine and, thus, had supercalcine on exposed surfaces. 
These leach results thus reveal little about the performance of a waste form using NiS-bonded graphite as a matrix, except perhaps in the (unlikely) event of waste form breakage.

\section{References}

Fullam, H. T. 1980. Use of Ceramic Materials in Waste-Package Systems for Geologic Disposal of Nuclear Wastes, PNL-3447, Pacific Northwest Laboratory, Richland, Washington.

Gray, W. J. 1980. A Study of the Oxidation of Graphite in Liquid Water for Radioactive Waste Storage Applications, PNL-SA-10045, Pacific Northwest Laboratory, Richland, Washington.

Kaae, J. L. and R. E. Bullock. 1980. Coatings for Ceramic Particles and Related Graphite Matrix Studies, GA-C 16136. General Atomic Company, San Diego, CA.

Westerman, R. E. 1980. Investigation of Metallic, Ceramic, and Polymeric Materials for Engineered Barrier Applications in Nuclear-Waste Packages, PNL-3484, Pacific Northwest Laboratory, Richland, WA. 


\section{D. CASTABLE CERAMIC MATRICES D. W. Brite and H. T. Blair}

Introduction

Castable ceramic materials have several desirable qualities that suggest their consideration as a matrix for containing nuclear waste marbles or pellets. They are inexpensive, form very strong monoliths, and are relatively simple to process. Their solidification does not require heating or pressing to produce a well consolidated product, and no atmosphere control is required during processing. Yet, the initial product is fluid so that it can be easily conveyed and cast in the shape of its container without fomning voids.

Castable ceramics do have some disadvantages. They contain typically 20 to $30 \%$ open porosity after setting so that they do not produce an impermeable barrier. They contain water which can result in steam and radiolytic gas production. Their heat transfer properties are not as good as graphite or metals. They are subject to attack by some chemicals commonly found in ground water. The effects of radiation on the structural integrity of the cement-waste interface is not yet well understood.

Three general types of castable ceramic matrix materials were evaluated for encapsulating nuclear waste marbles or pellets. One type is the hydraulic-bonded calcium silicates or Portland cements most commonly used in construction and presently used in solidifying low and intermediate level waste. These cements are further subdivided into five types plus various Portland cement and pozzolan combinations (T. M. Lea 1971). The second type is the hydraulic-bonded calcium aluminate cements. These cements are often used in refractory applications but are also superior to Portland cements in resistance to attack by sulfates, sea water, carbonic acid, and weak mineral acid solutions. They are not as resistant as Portland cement to attack by caustic alkali solutions (D. F. Orchard 1958). These cements range in alumina content from $39 \%$ to $96 \%$ depending on the intended application and supplier. The third type of castable evaluated is the chemically setting cements that are composed of alkali silicates which 
form silicon polymers to bind materials together $(G$. W. Read, Jr. and F. M. Veater 1974). These cements are extensively used in the chemical processing industries. They are resistant to most acids and alkalies from $\mathrm{pH}$ of 1 to 9 and are highly resistant to sulfates. However, they are more expensive and difficult to process than the hydraulic setting cements, and they may give off toxic vapors and highly alkaline liquid residues wile setting.

There are other castable mortars used in the chemical industries which were not considered in this study because it was felt they would not perform well in a high radiation environment. These include the modified phenol-formaldehyde mortars, the polyfurfuryl alcohol resin mortars, the epoxy and polyester mortars, and the sulfur mortars.

The application of the hydraulic-setting cements to the solidification of nuclear waste has been extensively studied at the Savannah River Laboratory (J. A. Stone 1977), at the Oak Ridge National Laboratory (J. G. Moore 1981, Naus 1981), at Pennsylvania State University (D. M. Roy and G. R. Gouda 1978), at Kernforschungszentrum Karlsruhe (D. Rudolph and R. Koster 1979), at the Pacific Northwest Laboratory (R. 0. Lokken 1978), and at Brookhaven National Laboratory (B. Manowitz et al. 1974). However, these studies were generally concerned with blending of waste solutions, sludges, or calcines into a concrete mixture rather than with using waste already solidified in the form of glass marbles or ceramic pellets as an aggregate in a cement matrix. Encapsulation of a waste pellet in concrete was evaluated at Pennsylvania State University and the results were promising (D. M. Roy 1974).

The main objectives in past studies of cements for solidifying nuclear waste is to minimize the permeability of the castings and prevent the leaching of the radioisotopes. Concrete permeability is usually prevented in construction applications by sealing the surface of the casting with a polymer. The methods evaluated for nuclear waste applications include: 1) minimizing the water-to-cement ratio during casting, 2) using additions of fly ash, pozzolan, various clays, and barium silicate hydrate to the cement and waste mixture, 3) applying heat and/or pressure to the casting in an autoclave or a hot 
press, and 4) using ideal size distribution of the aggregate for maximum particle packing (R. P. Heilich, G. Maczura, F. J. Rohr 1971). The effects of these processing variables on the leaching behavior of specific isotopes such as cesium and strontium and on radiolytic gas release were studied.

The conclusions of these previous studies are that concrete is a suitable material for fixation of nuclear waste. Several of these studies found the Portland-pozzolan cements slightly better than the other Portland cements and the calcium aluminate cements superior to the Portland cements for waste retention. Many of the additives studied did reduce the leaching rate of specific waste isotopes. Experimental

In the initial phase of the evaluation of castable ceramics as a matrix material, the cements shown in Table 3.D-1 were selected as representative of the three basic types of cement. Samples were prepared according to the manufacturers' instructions and cast in Teflon molds $1 \mathrm{in}$. dia. by 2-1/2 in. high. The sample processing conditions are presented in Table 3.D-2. In some cases additional castings loaded with simulated nuclear waste additives, consisting of disc-pelletized and sintered SPC-4E supercalcine pellets, or PNL 76-68 glass beads, were prepared. After the samples had cured for the specified time they were removed from the molds and volume percent open porosity was measured by a liquid immersion technique. Selected samples were subjected to leach testing as presented in the Chemical Durability of Matrix Forms section of this report.

Samples loaded with simulated nuclear waste were examined ceramographically. Typical macrostructures are shown in Figure 3.D-1. No significant reaction layer was observed between the waste forms and the cements cured at ambient temperature. Formation of a limited diffusion bond between the 76-68 glass and the Alfrax 66 cured at $500^{\circ} \mathrm{C}$ for one hour appears to have occurred. Because of the rough surface of the supercalcine pellets, it is not possible to determine by visual examination of polished samples if bonding occurred between the pellets and the $A 1$ frax 66 cured at $850^{\circ} \mathrm{C}$ for one hour. The existence of a bond between the waste forms and the cements may not be of 
great importance in the present case because of the relatively high measured volume percent open porosity in the cements ( 30 to 50\%).

As a result of their high volume percent open porosity, leaching performance of the castable ceramic matrices reported in Section 4 is poor. Consequently, based on these results, castable ceramic matrices for immobilization of high level nuclear wastes do not appear attractive in comparison to most of the other forms studied. 
TABLE 3.D-1. Compositional Comparison of Castable Ceramic Matrix Candidates Studied

\begin{tabular}{|c|c|c|c|c|c|c|c|c|c|c|c|c|c|c|c|}
\hline \multirow[b]{2}{*}{ Candidate } & \multicolumn{15}{|c|}{ Composition, wt\% } \\
\hline & Type & $\mathrm{A}_{2} \mathrm{O}_{3}$ & $\underline{B_{2} 03}$ & $\underline{\mathrm{CaO}}$ & $\underline{\mathrm{Fe} 0}$ & $\mathrm{Fe}_{2} \mathrm{O}_{3}$ & $\underline{\mathrm{K}_{2} \mathrm{O}}$ & $\underline{\mathrm{MgO}}$ & $\mathrm{Na20}$ & $\underline{\mathrm{P} 205}$ & $\underline{\mathrm{SO}_{3}}$ & $\underline{\text { SiC }}$ & $\mathrm{SiO} 2$ & $\mathrm{IiO}_{2}$ & $\underline{\mathrm{ZrO}} 2$ \\
\hline Portland Type II Cement & 1 & 4.6 & & 63.3 & & 4.3 & & 2.5 & & & 1.7 & & 22.4 & & \\
\hline $\begin{array}{l}\text { Fondu Calcium Aluminate } \\
\text { Cement }(a)\end{array}$ & 2 & 50 & & 50 & & & & & & & & & & & \\
\hline A1 frax $66^{(b)}$ & 2 & 96.0 & & 4.0 & 0.1 & & & & & & & & $\operatorname{Tr}$ & & \\
\hline Alfrax $66 \times F^{(b)}$ & 2 & 96.0 & & 4.0 & 0.1 & & & & & & & & $\operatorname{Tr}$ & & \\
\hline Ceramacast $510^{(c)}$ & 2 & 84.8 & & 5.4 & & 0.34 & & 0.09 & 0.8 & & & & 1.1 & & \\
\hline Cotronics RTC-60 $(d)$ & 2 & 86.7 & & 3.8 & & 0.18 & & & 0.9 & 0.27 & & & 0.3 & & \\
\hline $\begin{array}{l}\text { Sauereisen No. } 33 \text { Acid-Alk } \\
\text { Cement(e) }\end{array}$ & 3 & 12.5 & & 3.3 & & 0.1 & & 0.1 & 8.4 & 0.25 & & & 56.7 & & \\
\hline Swindress Bond $100^{(f)}$ & 3 & 0.24 & & & & 0.1 & 0.2 & & 6.2 & 0.14 & & & 56.7 & & \\
\hline Swindress Bond $110^{(f)}$ & 3 & 0.27 & & & & 0.1 & 0.2 & & 8.6 & 0.15 & & & 57.8 & & \\
\hline Swindress Bond $120^{(f)}$ & 3 & 0.23 & & & & 0.1 & 0.2 & & 6.1 & 0.13 & & & 67.4 & & \\
\hline Cotronics $919^{(d)}$ & 3 & 0.37 & 0.41 & 0.36 & & 0.19 & & 11.3 & 0.50 & 7.4 & & & 23.2 & 0.1 & 51.0 \\
\hline Firefrax $B S T-D(b)$ & $\cdots$ & 50 & & & & 1 & & & & & & & 42 & & \\
\hline Carbofrax $12^{(b)}$ & --- & 4 & & & & 2 & & & & & & 83 & 10 & & \\
\hline
\end{tabular}

(a) Lone Star Lafarge, Inc., Norfolk, Virginia

(b) The Carborundum Company, Refractories Division, Box 367, Niagara Falls, NY 14302.

(c) Arenco Products, Inc., Box 429, Ossining, New York 10562

(d) Cotronics Corp., 3379 Shore Parkway, Brooklyn, New York 11235

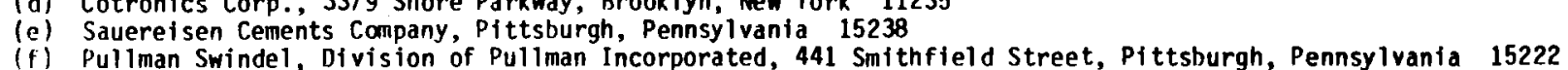


TABLE 3.D-2. Castable Matrix Materials Preparation Conditions

\begin{tabular}{|c|c|c|c|c|c|}
\hline \multirow[b]{2}{*}{ Candidate } & \multirow[b]{2}{*}{$\begin{array}{r}\text { Water To } \\
\text { Solid Ratio } \\
\end{array}$} & \multicolumn{2}{|c|}{$\begin{array}{c}\text { Volume \% } \\
\text { Waste Loading }\end{array}$} & \multirow[b]{2}{*}{$\begin{array}{l}\text { Curing } \\
\text { Temperature, }{ }^{\circ} \mathrm{C}\end{array}$} & \multirow{2}{*}{$\begin{array}{c}\text { Volume } \\
\text { Open } \\
\text { Porosity }\end{array}$} \\
\hline & & $\begin{array}{l}\text { SPC-4E } \\
\text { Pellets }\end{array}$ & $\begin{array}{c}76-68 \\
\text { Glass Beads } \\
\end{array}$ & & \\
\hline Sauereisen No. 33 & 0.182 & & & 24 & N.D \\
\hline Swindress Bond 100 & 0.140 & & & 25 & N.D. \\
\hline Swindress Bond 110 & 0.140 & & & 25 & N.D. \\
\hline Swindress Bond 120 & 0.140 & & & 25 & N.D. \\
\hline Al frax 66 & 0.124 & 29.0 & 3.3 & $\begin{array}{l}850 \text { (pellets) } \\
500 \text { (beads) }\end{array}$ & 27.8 \\
\hline A1 frax $66 \times F$ & 0.208 & 33.5 & 38.8 & $\begin{array}{l}850 \text { (pellets) } \\
500 \text { (beads) }\end{array}$ & N.D. \\
\hline Ceramacast 510 & 0.175 & 31.7 & 38.5 & 22 & 31.9 \\
\hline Firefrax BST-D & 0.178 & & & 70 & N.D. \\
\hline Carbofrax 12 & 0.305 & & & 70 & N.D. \\
\hline Cotronics RTC-60 & 0.148 & & & 22 & 32.3 \\
\hline Cotronics 919 & 0.155 & 45.8 & 55.6 & 22 & 28.0 \\
\hline $\begin{array}{l}\text { Lehigh Portland } \\
\text { Cement, Type II }\end{array}$ & 0.351 & & & 22 & 48.6 \\
\hline $\begin{array}{l}\text { Fondu Calcium } \\
\text { Aluminate Cement }\end{array}$ & 0.344 & & & 22 & 47.3 \\
\hline
\end{tabular}

N.D. = Not Determined 


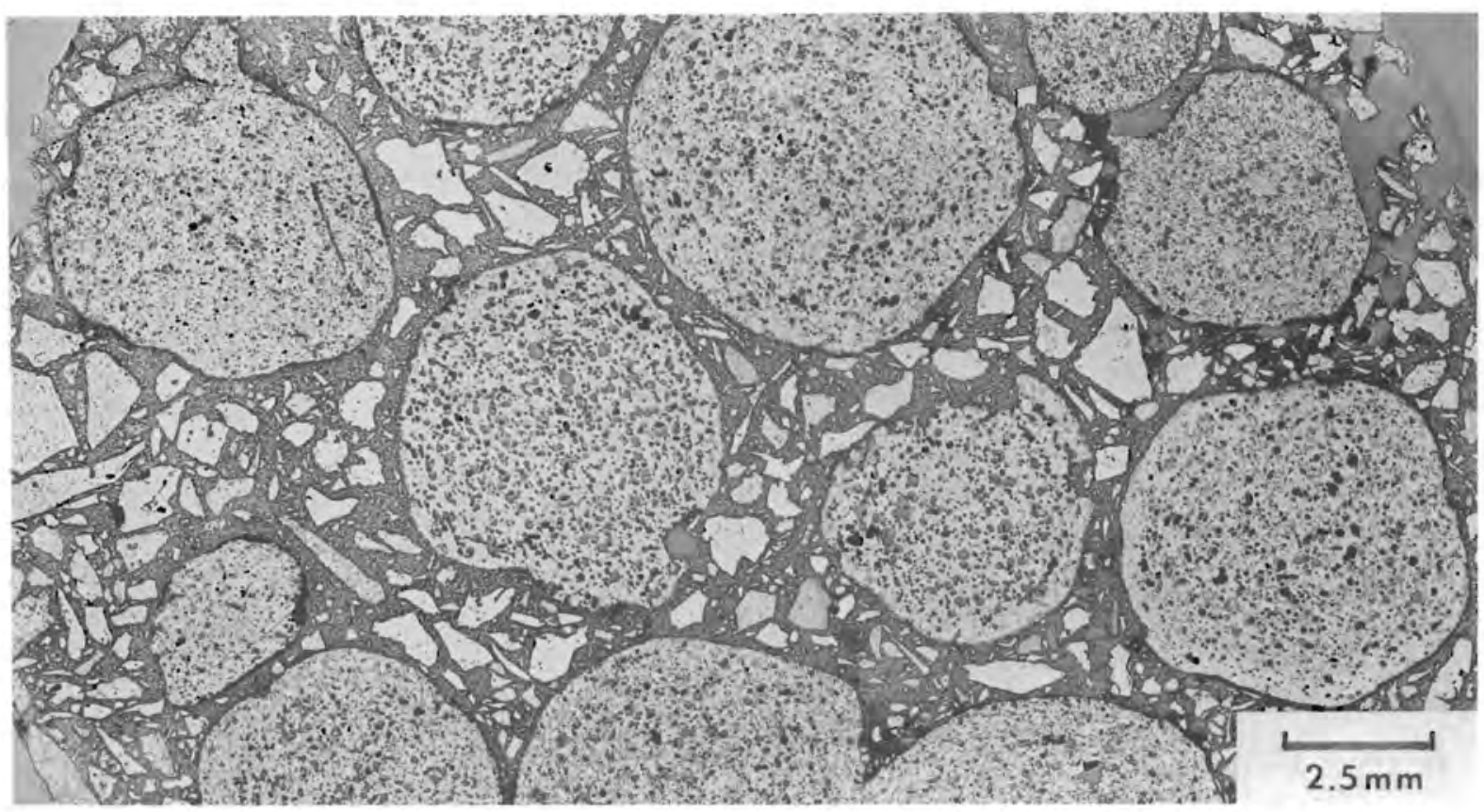

a) SPC-4E supercalcine pellets in Ceramcast 510

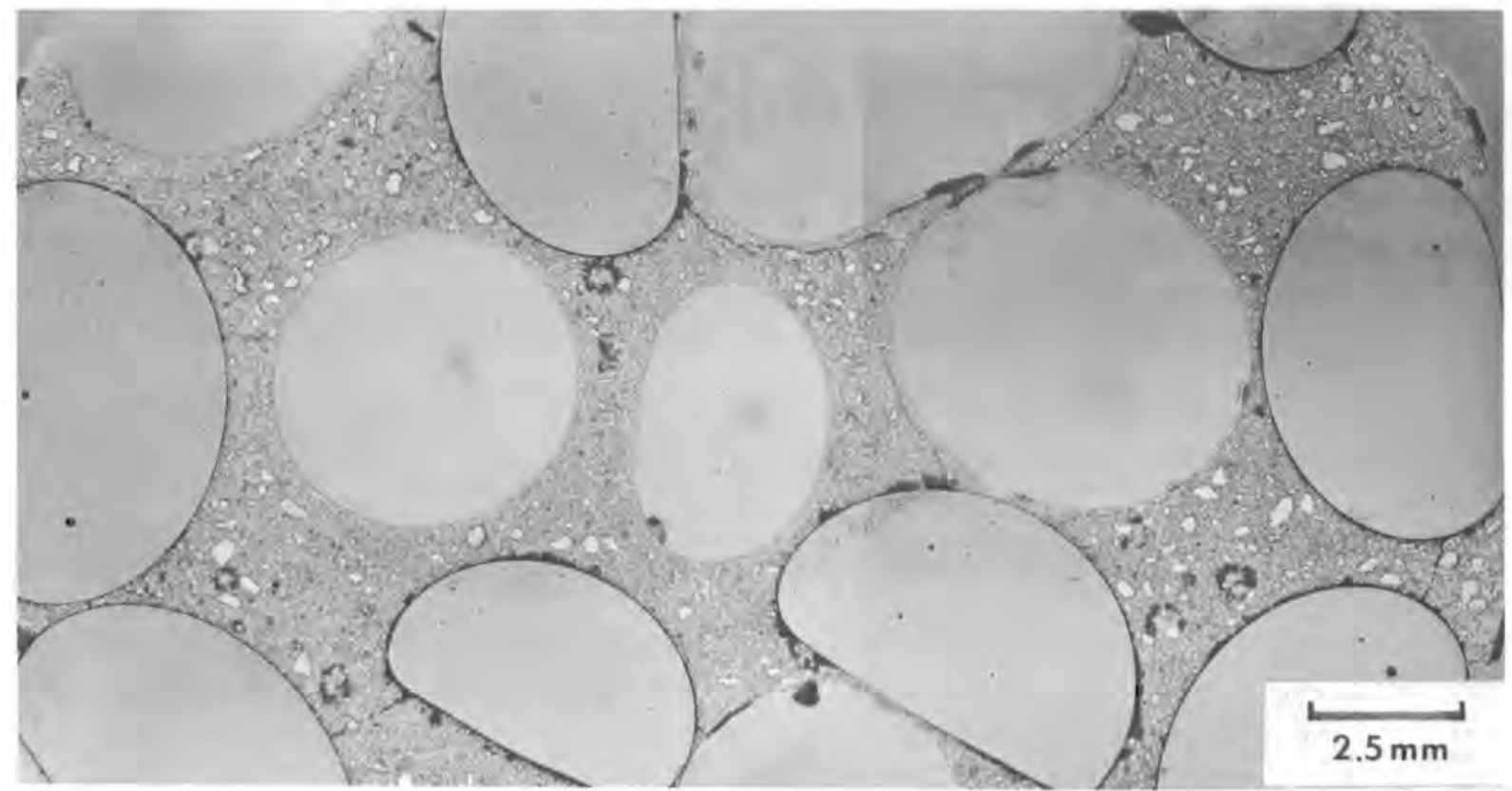

b) $76-68$ glass beads in Cotronics 919

FIGURE 3.D-1. Selected Ceramic Pellet and Glass Bead Waste Forms Encapsulated in Castable Ceramic Matrices 


\section{References}

Heilich, R. P., G. MacZura, F. J. Rohr, 1971. "Precision Cast 92-97\% Alumina Ceramics Bonded with Calcium Aluminate Cement". Ceramic Bulletin, 5(6), 548-554.

Lea, F. M., 1971. The Chemistry of Cement, 3rd. Edition, Chemical Publishing Co., Inc., New York, NY.

Lokken, R. 0., 1978. A Review of Radioactive Waste Immobilization in Concrete. PNL-2654, Pacific Northwest Laboratory, Richland, WA. 99352.

Manowitz, B., 1974. Savannah River Laboratory Long-Term Waste Storage Program, Progess Report 5. BNL 18978, Brookhaven National Laboratory, Upton, NY. 11973.

Moore, J. G., 1981. A Survey of Concrete Waste Forms, Alternate Nuclear Waste Forms and Interactions in Geologic Media, CONF-8005107, pp. 194-216, U.S. Dept. of Energy, Office of Energy Research, Division of Material Sciences, Washington, D.C. 20545.

Moore, J. G., E. Newman and G. C. Rogers, 1979. Radioactive Waste Fixation in FUETAP (Formed Under Elevated Temperature and Pressure) Concretes - Experimental Program and Initial Results. DRNL/TM-6573, Oak Ridge National Laboratory, Oak Ridge, TN 37830.

Naus, D. J., 1981. Task 2: Concrete Properties in Nuclear Environment A Review of Concrete Material Systems for Application to Prestressed Concrete Pressure Vessels. ORNL/TM-7632, Oak Ridge National Laboratory, oak Ridge, TN 37830.

Orchard, D. F., 1958. Concrete Technology, Volume I Properties of Materials, Contractors Record Limited, London, England.

Read, G. W., Jr. and F. M. Veaton, 1974. Brick Mortar: Good to $1000^{\circ} \mathrm{C}$, Canadian Chemical Processing, 58(7) 32-34.

Roy, D. M. and G. R. Gouda, 1978. "High Level Radioactive Waste Incorporation into Special Cements", Nuclear Technology, 40, 214-219.

Roy, D. M. and G. R. Gouda, 1974. Hot Pressed Cement in Radioactive Waste Management. The Materials Research Laboratory, University Park, PennsyTvania 16802.

Rudolph, G. and R. Koster, 1979. Material Studies on Sol idification of Medium Level Waste Solutions with Cement: Leachability of Cesium and Strontium, PNL-TR-387, Pacific Northwest Laboratory, Richland, WA. 99352. Translated from German, Stoffliche Untersuchungen zur Verfestingung mittelaktiver Abfallosungen mit Zement: Auslaugbarkeit von Casium und Strontium, KdK2842, Kernforschungzentrum, Karlsruhe, GmbH, Karlsruhe, West Germany. 
Stone, J. A., 1977. Evaluation of Concrete As A Matrix for Solidification of Savannah River Plant Waste. DP-1448, Savannah River Laboratory, Aiken, South Carolina 29801. 


\section{CHEMICAL DURABILITY OF MATRIX FORMS $\quad$ C. Q. Buckwalter}

\section{Introduction}

The materials investigated in the preceding sections were selected for possible matrix use because of their corrosion resistance, mechanical strength, and/or the compatibility of process fabrication with the waste core (glass or ceramic) (Jardine and Steindler 1979; Rusin et al, 1979). There were two aspects considered in the evaluation of the chemical durabil$i$ ty of matrix encapsulated waste forms. First was the question of synergism which may arise when materials of different properties are placed in the same leach solution. The second was the effectiveness of the waste core/ matrix assembly in decreasing net waste form corrosion. To evaluate these questions, leach studies of the component matrix materials and complete waste forms were undertaken using static leach tests based on the Materials Characterization Center test method MCC-1. The experiments had several objectives and are discussed in the following sections in three subareas: 1) evaluation of the durability of the matrix materials, 2) examination of possible interactions between the matrix and waste core components, and finally 3) examination/comparison of complete matrix forms.

\section{Experimental}

Matrix/waste core interactions were studied using the $\mathrm{MCC}-1$ procedure in deionized water at $90^{\circ} \mathrm{C}$ for $3,7,14$ and 28 day time intervals (Barnes and Strachan 1981). To evaluate the interactions, test cells were fabricated out of selected materials and substituted for the reference, tefion, as the leaching container. Figure 4-1 shows a diagram of a representative matrix test cel1. PNL 76-68 glass was leached in containers made from graphite, tin, lead, copper, aluminum, and titanium at a glass surface area to solution volume ratio $(S A / N)$ of $10 \mathrm{~m}^{-1}$. Samples were suspended by a teflon line and the lids sealed with a teflon gasket. The inside of all containers were sanded with 600 grit silicon carbide paper and ultrasonically cleaned to establish a fresh, clean surface. Blank test cells with no glass present were leached to determine the corrosion rates of the matrix materials.

Matrix/waste form assemblies were fabricated as monoliths and leached conforming to MCC-1 test procedures. Due to the large number of matrix 


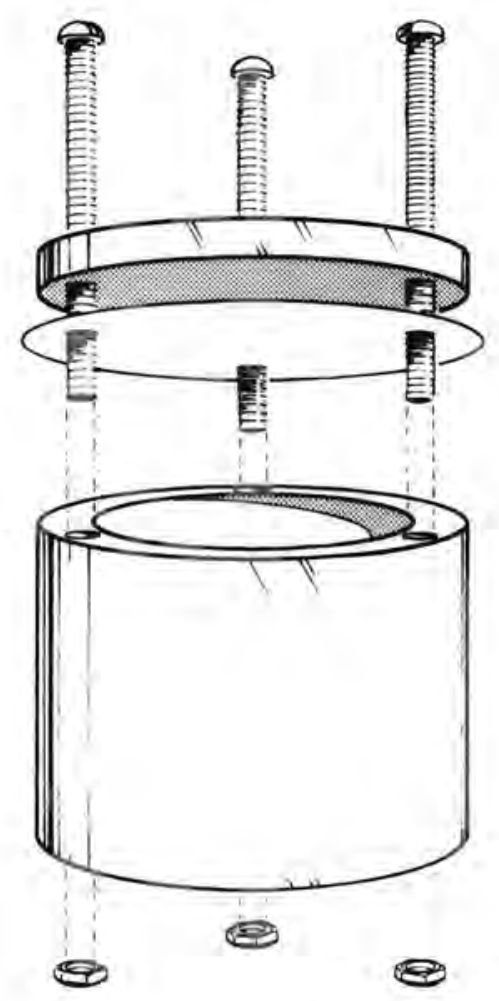

FIGURE 4-1. Representative Diagram of Leach Containers Manufactured from Matrix Materials

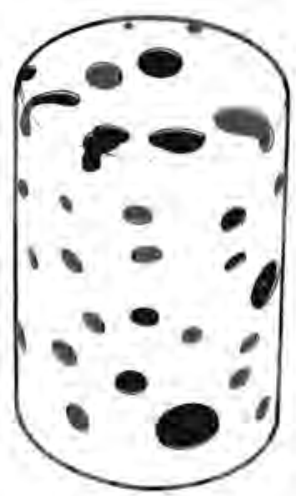

FIGURE 4-2. Schematic Representation of Composite Matrix/waste Form Configuration 
waste forms considered, a scoping test was performed to provide the needed comparison. The test was performed for 14 days at $90^{\circ} \mathrm{C}$ in deionized water, at a SA/V of $10 \mathrm{~m}^{-1}$, based on geometric area for the waste form. Figure 4-2 shows an example of a lead/waste core monolith. In this sample there are areas of exposed glass beads. That exposure is not characteristic of all waste forms studied. In the cases of Portland cement, Cotronics 919 cement, $7570 \mathrm{glass,} 1720 \mathrm{glass,}$ and graphite, the waste cores were completely encapsulated. This variation in sample configuration affects the exposed waste core surface area and the true SA/V ratio, complicating experimental interpretation. The impact of this $S A / N$ variation is discussed further in the following section, and its significance has been addressed el sewhere (Buckwalter et al. 1981).

PNL 76-68 glass marbles and SPC-4E pellets were encapsulated in the above described matrix forms. Since the lead/waste glass system showed the best performance from scoping studies, this system was chosen to be studied in a more comprehensive manner. Additional monoliths were fabricated using the Savannah River waste glass TDS-211 as the lead encapsulated waste form. These samples were then subjected to the $M C C-1$ leach test for the required times, temperature, $S A / V$, and solvents as described previously.

Leachate analysis was performed by Inductively Coupled Argon Plasma (ICP) Spectroscopy. Solid state analysis on selected glass bead samples was done with Secondary Ion Mass Spectroscopy (SIMS), X-ray Photoelectron Spectroscopy (XPS), Scanning Electron Microscopy (SEM), and Energy Dispersive $X$-ray Analysis (EDAX).

Results and Discussion

Matrix Materials Durability - Table 4-1 presents the pH and ICP leachate analyses from the matrix cell test blanks (i.e., no waste present). The results shown are therefore a measure of the reactivity of the various materials. Titanium, $\mathrm{Ti}-6 \% \mathrm{Al}-4 \% \mathrm{~V}, \mathrm{TiO}_{2}, \mathrm{ZrO}_{2}$, and tin analyses are below detection, aluminum and copper are both less than $1 \mathrm{ppm}$, and lead reaches $25 \mathrm{ppm}$. The $\mathrm{pH}$ values of the leachates are also indicative of the amount of interaction. Initially, the deionized water had a pH of 6.0. Titanium, $\mathrm{Ti}-6 \% \mathrm{~A} 1-4 \% \mathrm{~V}$, and tin results are near this value, copper, aluminum, and Al-12\% Si show a small pH change, while lead attains a typical pH equilibrium value characteristic of lead oxide $(\mathrm{pH}=10.2)$ (Parks 1965). The 
TABLE 4-1. Leachate Analysis from Metric Cell Test Blanks

\begin{tabular}{|c|c|c|}
\hline Material & $\mathrm{ppm}$ & $\mathrm{pH}$ \\
\hline 1720 Glass & & 10.8 \\
\hline B & 2 & \\
\hline $\mathrm{Si}$ & 24 & \\
\hline $\mathrm{Na}$ & 24 & \\
\hline Lead & 25 & 10.2 \\
\hline Al $12 \% \mathrm{Si}$ & & 7.1 \\
\hline Al & 6.7 & \\
\hline$S i$ & 8.7 & \\
\hline Copper & .7 & 7.1 \\
\hline Aluminum & .5 & 7.5 \\
\hline Tin & $<.005$ & 5.8 \\
\hline Titanium & $<.002$ & 5.8 \\
\hline Graphite & NA & 7.5 \\
\hline \multicolumn{3}{|l|}{ Titanium } \\
\hline$-6 \% A-4 \% V$ & $<.002$ & 6.2 \\
\hline $\mathrm{TiO}_{2}$ & $<.002$ & 4.4 \\
\hline $\mathrm{ZrO}_{2}$ & $<.008$ & 4.8 \\
\hline
\end{tabular}


aluminosilicate glass, code 1720 , is the least durable matrix material studied in these experiments with glass constituents dissolving while the $\mathrm{pH}$ reaches 10.8. Carbon analysis was not made for the test in the graphite cell.

Matrix Cell Tests - The experiments undertaken to evaluate possible interactions between the various matrix materials and waste glass PNL 76-63 have been reported in more detail el sewhere (Buckwalter and Pederson 1981). This section summarizes the key features. The tests involved leaching glass in containers constructed of different metals (or graphite) under static (MCC-1) conditions.

The ICP leachate analysis for the release of silicon from glass PNL 76-68 tested in various cells is presented in Figure 4-3. Titanium, copper, graphite, and tin containers resulted in waste core leaching results similar to teflon. The $\mathrm{pH}$ of the leachate was the same, approximately 9.5, also indicating analogous reaction rates. The aluminum and lead containers caused decreased silicon release by one order of magnitude and better than two orders of magnitude, respectively. The $\mathrm{pH}$ of the aluminum container leachate was 8.5 and that of lead was 10.2. Other glass constituents had release rates which showed the same trend as the silicon analysis, with most of the containers having little or no effect, while aluminum and lead caused major decreases. Glass leached in the lead container produced leachates with concentrations at or below detection limits for all elements tested.

A graphite test cell similar to the metal cells was also fabricated, however with some complications. To avoid permeation of the solvent through the cell, an organic resin was impregnated into the cell walls. The first set of cells proved ineffective due to zinc cation contamination which buffered the $\mathrm{pH}$ to 3 . At this $\mathrm{pH}$ the waste glass exhibits enhanced dissolution. The next set of cells were free of contamination and ICP analysis of the leachate indicated insignificant interaction with solution concentrations analogous to those from the tefion reference cell. This result is expected based on the very low graphite/water reaction rates discussed in the preceding section of this report (see Section 3.C).

Polished SEM cross-sections for representative samples leached for 28 days are shown in Figure 4-4. Depleted layers of 7, 8, 9, and 10 microns 


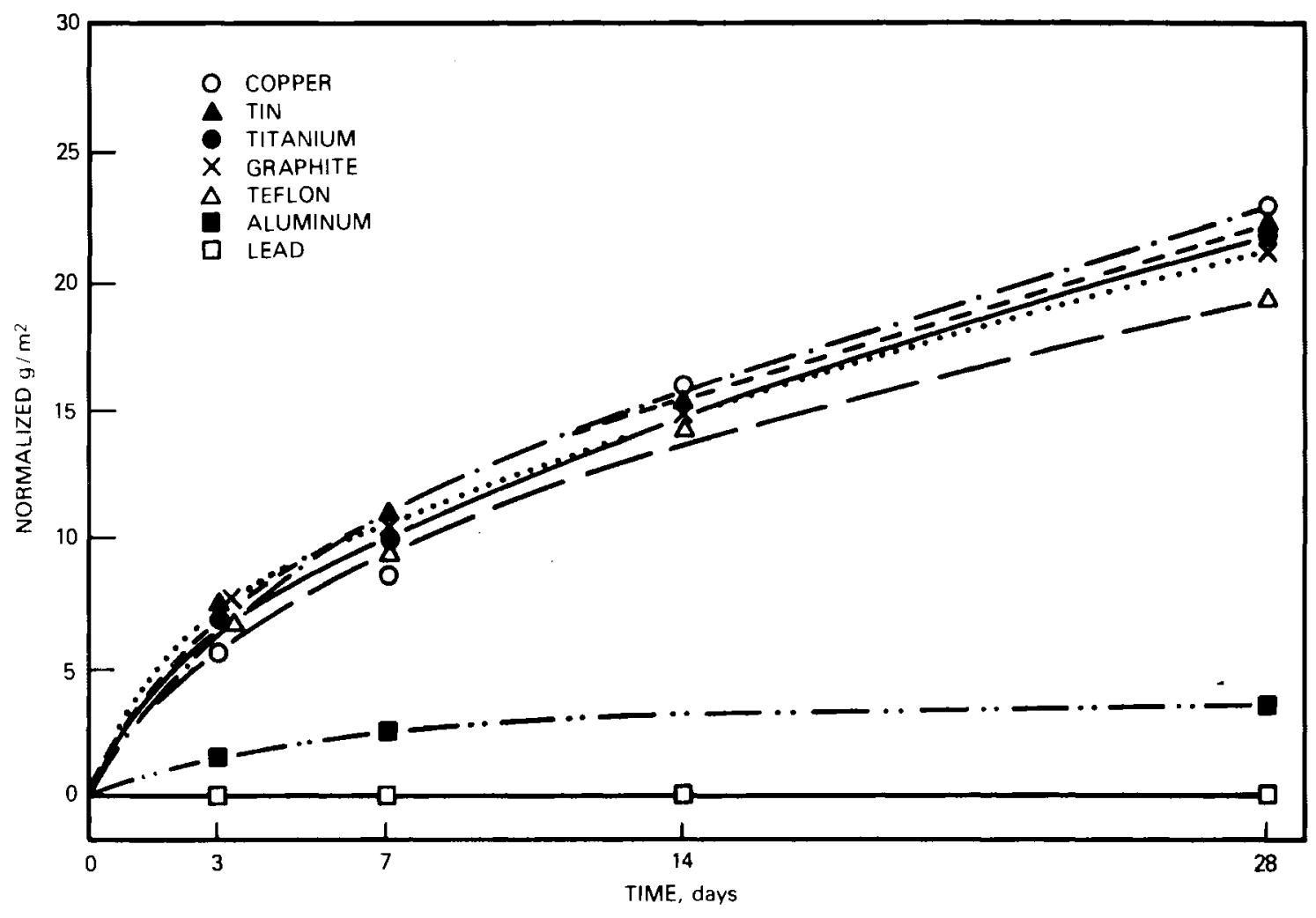

FIGURE 4-3. Silicon release for glass PNL-76-68 leach tested in $\mathrm{Cu}, \mathrm{Ti}, \mathrm{Sn}, \mathrm{Al}, \mathrm{Pb}$, Graphite and Teflon leach cells

are measured for glass leached in tin, titanium, teflon and copper containers respectively. Glass leached in aluminum shows a 0.8 micron layer. For lead, a reaction layer could not be detected at 30,000X magnification. EDAX analysis of the glass surface showed a small amount of aluminum sorption on the sample leached in aluminum. The sample leached in the lead container was covered with lead containing crystallites as indicated in the SEM picture in Figure 4-5. The coverage was not uniform, as confirmed by EDAX analysis, as shown in Figure 4-6.

XPS inspection of the lead covered glass surfaces indicates lead in a +2 oxidation state, bound as an oxide but assignment of a specific molecular species was not possible. XPS results for both the container and glass surfaces are presented in Table 4-2. In all containers except lead, aluminum, and tefion, sorption of glass constituents was detected on the walls 


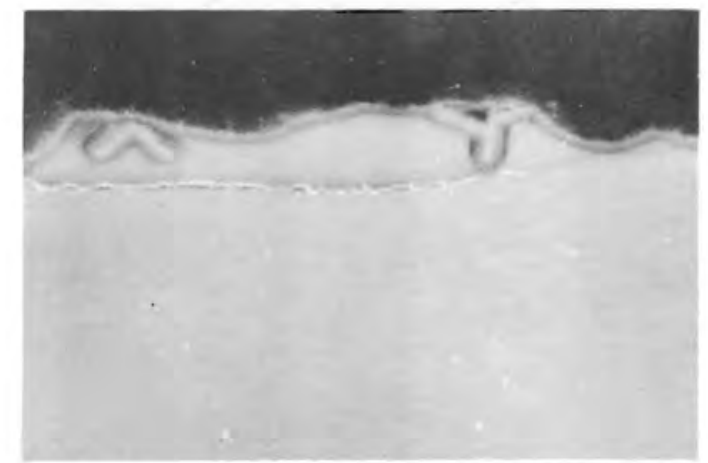

COPPER

$\infty$

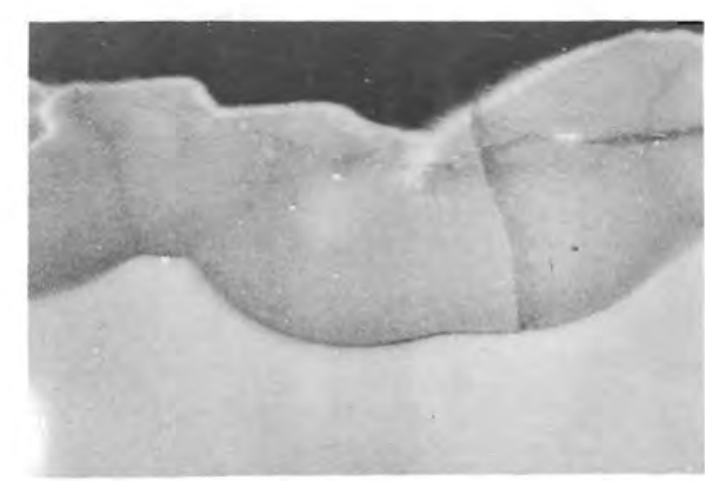

ALUMINUM

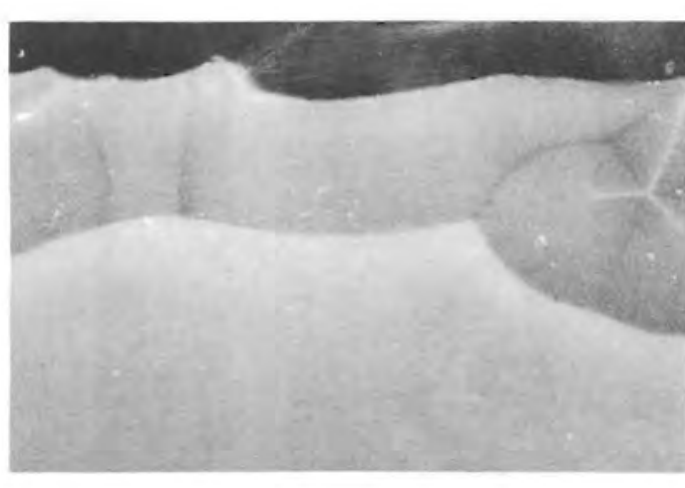

TIN

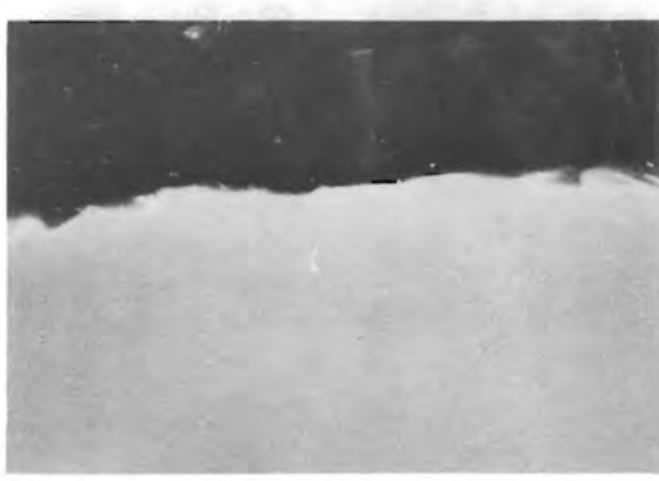

LEAD

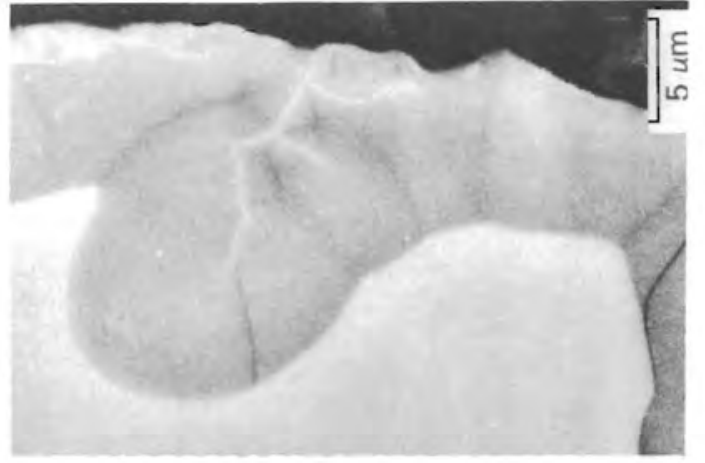

TITANIUM

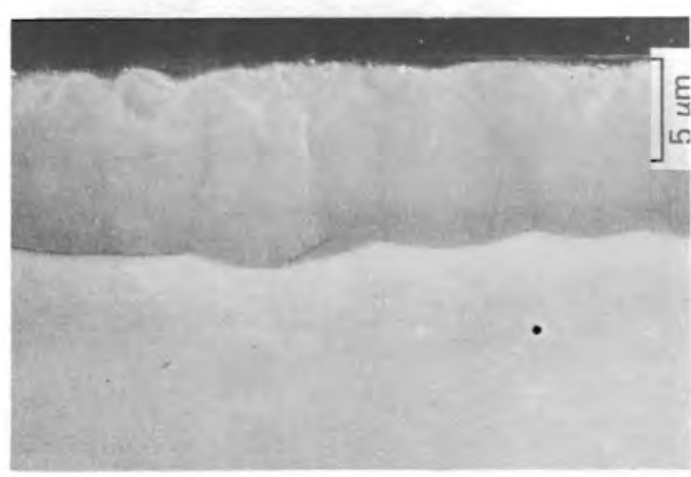

TEFLON

FIGURE 4-4. Cross sections of waste glass samples show depleted layers. The aluminum container sample exhibits a leach layer of $8 \mathrm{~nm}$ while the lead container sample depleted layer is not detected. 


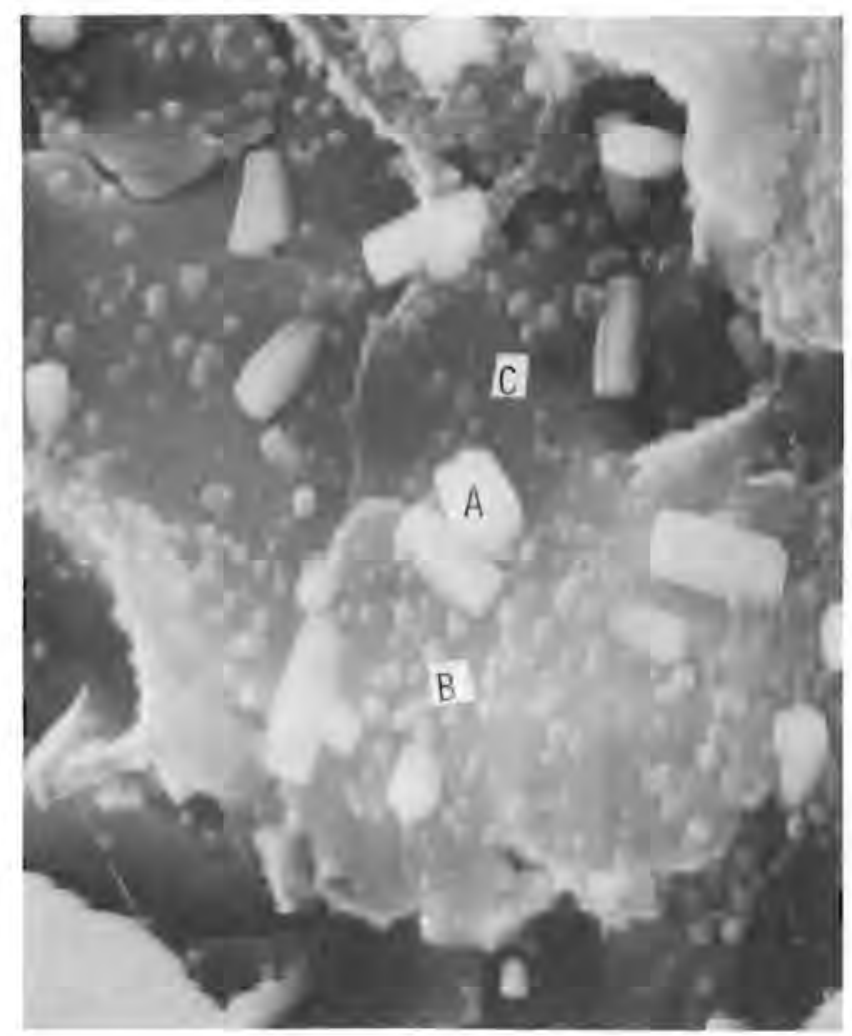

FIGURE 4-5. Surface of 76-68 Waste Glass Exhibiting Growth of Lead Crystallites.

of the container. XPS analysis of the glass samples showed that only in the cases of aluminum and lead was there sorption of the container material onto the glass surface. Depth profile analysis confirmed that the reaction depth for glass leached in lead was very small, being $<50 \AA$.

Waste Form Tests - Tables 4-3 and 4-4 summarize the 14 day leach data for all the matrix waste forms studied. The data are normalized to the waste form surface area and the elemental concentrations in the waste form. The results shown in the first column of each table were obtained by leaching several glass or supercalcine cores at an SA/V of $10 \mathrm{~m}^{-1}$. The data for the matrix forms were also obtained with a geometric surface area/solution volume ratio of $1 \mathrm{~m}^{-1}$. In assessing the value of matrix encapsulation on leach resistance, one approach is to think of a comparison between equal right circular cylindrical forms, or "monoliths", one of which is totally 

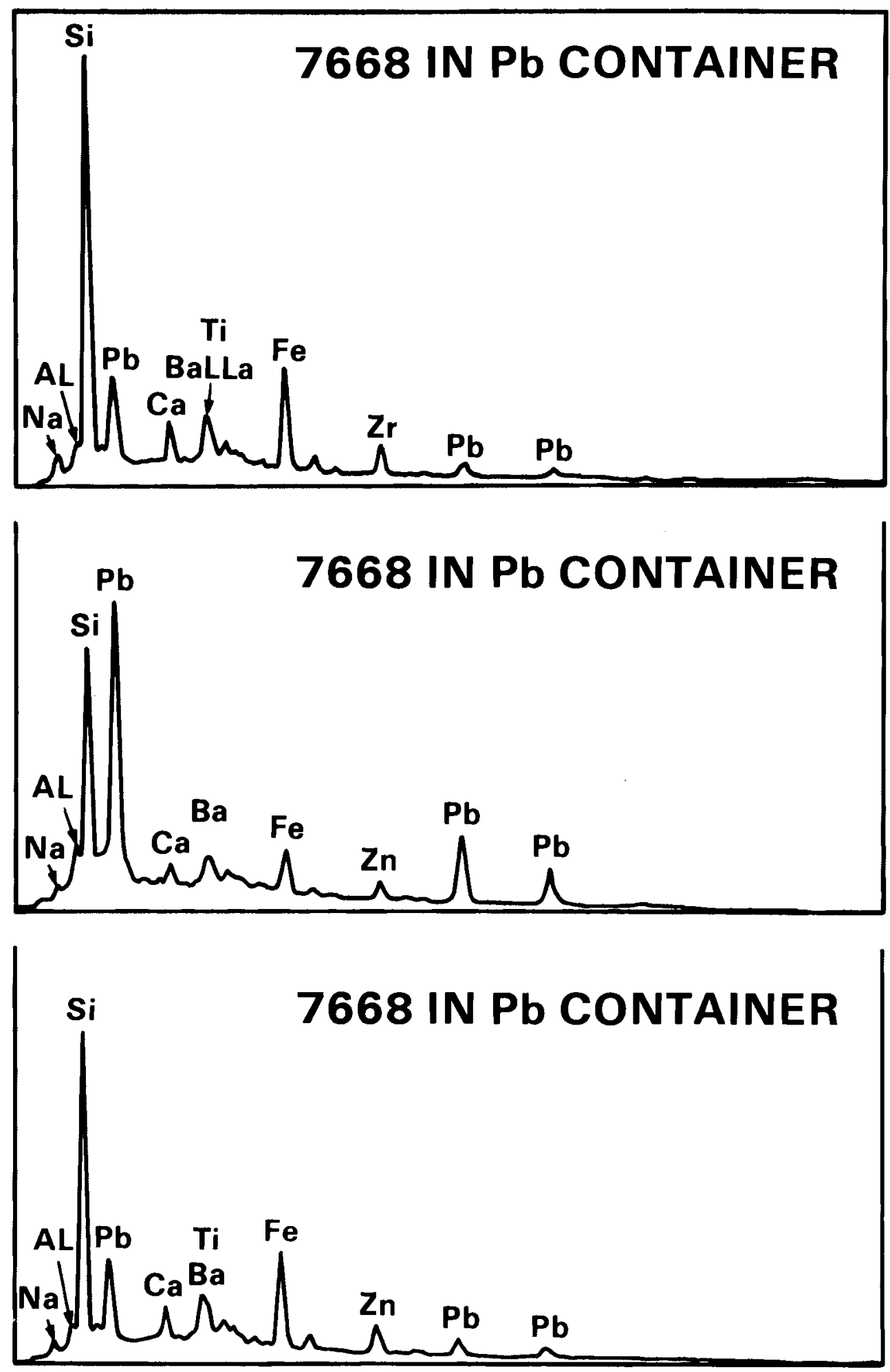

FIGURE 4-6. EDAX Analysis Illustrating Lead Detected at all Positions in Figure 4-5. 
TABLE 4-2. Surface Concentrations (atom percent) of Elements for Glass 76-68 Leached in Deionized Water (from XPS analysis)

\begin{tabular}{|c|c|c|c|c|c|c|c|c|c|c|c|c|c|}
\hline & & $\begin{array}{c}\text { Al } \\
\text { Contalner }\end{array}$ & $\begin{array}{l}\text { Glass } \\
\text { Leached } \\
\text { In Al }\end{array}$ & $\begin{array}{c}\mathrm{Cu} \\
\text { Container }\end{array}$ & $\begin{array}{l}\text { Glass } \\
\text { Leached } \\
\text { In Cu } \\
\end{array}$ & $\begin{array}{c}\mathrm{Pb} \\
\text { Container }\end{array}$ & $\begin{array}{c}\text { Glass } \\
\text { Leached } \\
\text { in } \mathrm{Pb} \\
\end{array}$ & $\begin{array}{c}\text { Sn } \\
\text { Contalner }\end{array}$ & $\begin{array}{l}\text { Glass } \\
\text { Leached } \\
\text { In Sn } \\
\end{array}$ & $\begin{array}{c}\text { T1 } \\
\text { Container }\end{array}$ & $\begin{array}{l}\text { Glass } \\
\text { Leached } \\
\text { In TI } \\
\end{array}$ & $\begin{array}{l}\text { Teflon } \\
\text { Container }\end{array}$ & $\begin{array}{l}\text { Glass } \\
\text { Leached } \\
\text { in Teflon }\end{array}$ \\
\hline & Al & 29.9 & 8.0 & -- & -- & -- & -- & -- & -- & -- & -- & -- & -- \\
\hline & $\mathrm{Cu}$ & -- & -- & 24.6 & -- & -- & -- & -- & -- & -- & -- & -- & -- \\
\hline & $\mathrm{Pb}$ & -- & -- & -- & -- & 30.8 & 25.0 & -- & -- & -- & -- & -- & -- \\
\hline & $S n$ & -- & -- & -- & -- & 9.7 & 6.4 & 12.2 & - & -- & -- & -- & -- \\
\hline & $\mathrm{Ti}$ & -- & -- & -- & $=-$ & -- & -- & -- & -- & 20.5 & -- & -- & -- \\
\hline & B & -- & 12.1 & -- & -- & -- & -- & -- & 3.6 & -- & -- & -- & -- \\
\hline N & C & -- & -- & -- & -- & -- & -- & -- & -- & -- & -- & 62.9 & -- \\
\hline & $\mathrm{Fe}$ & -- & 8.8 & -- & 2.0 & -- & -- & -- & 3.0 & 2.7 & 3.5 & -- & 3.7 \\
\hline & $\mathrm{Ni}$ & -- & 2.4 & -- & 0.2 & -- & -- & -- & 1.0 & -- & 1.6 & -- & 1.9 \\
\hline & Si & -- & 8.0 & 13.9 & 19.5 & -- & 7.9 & 16.2 & 17.0 & 8.3 & 23.5 & 1.4 & 20.6 \\
\hline & $\mathrm{Zn}$ & -- & 15.6 & -- & 28.6 & -- & -- & 7.8 & 25.8 & 3.1 & 10.1 & -- & 9.6 \\
\hline & $\mathrm{Zr}$ & -- & 0.5 & -- & -- & -- & -- & -- & 0.2 & 0.4 & -- & -- & 0.4 \\
\hline & 0 & 20.1 & 44.6 & 61.5 & 49.5 & 59.6 & 60.7 & 56.0 & 49.4 & 65.1 & 61.4 & 5.0 & 63.5 \\
\hline & $F$ & -- & -- & -- & -- & -- & -- & -- & -- & -- & -- & 62.9 & -- \\
\hline
\end{tabular}


waste core product while the other is individual waste cores encapsulated in a matrix. For given conditions of time, temperature, and $S A N$, if the matrix does not provide a physical barrier or a positive synergism with the waste core, then leaching will be greater for the cores within the matrix waste form simply because the surface area of the waste core material is greater. Since the leach rates of unencapsulated waste cores tested at an $S A / N$ of $1 \mathrm{~m}^{-1}$ are equal to those of a single glass or supercalcine "monolith" tested at the same $S A / V$ ratio, this comparison can be made from the present data. Results in Table 4-3 for Glass 76-68 show that the matrices are effective in that the leach values for the matrix encapsulated cores are less than for the glass "monolith" (column 1). The very large numbers that appear for some elements generally are the result of that element being leached from the matrix material as well as from the waste core. Placing supercalcine cores in a matrix did not reduce the leach values to less than those for the supercalcine "monolith", as illustrated in Table 4-4. The reason for the apparent failure of matrices to inhibit supercalcine leaching is not entirely understood, though some possibilities are discussed later.

In considering the manner in which the data for the encapsulated waste cores were normalized for elemental concentrations, it should be recognized that the procedure introduces a bias in favor of the matrix waste forms by factors of one to five, depending upon matrix material. Also, as suggested in the experimental section, some care needs to be exercised in interpreting these results because of uncertainties in the true SA/V. Previous studies of glasses in particular, show large effects on reaction rates attributable to either the influence of $\mathrm{pH}$ on network dissolution or to solution saturation effects (McVay and Buckwalter 1980). Thus, at high SA/N, high pH values are rapidly reached causing increased silica dissolution. On the other hand, individual elements approach their solubility limits more quickly at high SA/N, thereby decreasing their apparent leach rates. Part of the reason for uncertainties in the true $S A / V$ was because the exposure of waste cores varied from waste form to waste form and in many cases was zero. In Table 4-3 the lead sample was the only sample with exposed waste cores. In Table 4-4, lead, Al-Si, and the two glass matrix forms had exposed waste cores while the remaining samples had completely encapsulated cores. In 

TABLE 4-3. Leach Data for Matrix Encapsulated 76-68 Glass in Units of Normalized Elemental Loss

$\stackrel{\wp}{\risingdotseq}$

\begin{tabular}{|c|c|c|c|c|}
\hline $\begin{array}{l}76-68 \text { Glass } \\
\text { in } 100 \% \mathrm{~Pb}\end{array}$ & $\begin{array}{c}76-68 \text { Glass } \\
\text { in } 7570 \text { Glass } \\
\end{array}$ & $\begin{array}{c}76-68 \text { Glass } \\
\text { in } 1720 \text { Glass }\end{array}$ & $\begin{array}{c}76-68 \text { Glass in } \\
\text { Type II Portland } \\
\text { Cement }\end{array}$ & $\begin{array}{c}76-68 \text { Glass in } \\
\text { Cotronics } 919 \text { Castable }\end{array}$ \\
\hline 0.05 & 22.09 & 0.56 & 0.13 & 11.64 \\
\hline 0.01 & 0.81 & 0.08 & 1.39 & -- \\
\hline 0.01 & 0.09 & 0.24 & 8.51 & 0.31 \\
\hline 0.02 & 0.01 & 0.40 & 1.51 & 0.07 \\
\hline 0.03 & 0.09 & 0.52 & 0.06 & 0.27 \\
\hline 0.03 & 0.14 & 0.64 & 3.74 & 0.70 \\
\hline 5.40 & 18.99 & -- & -- & -- \\
\hline 0.01 & 0.04 & 0.31 & 0.02 & 0.96 \\
\hline- & 0.02 & 0.13 & 14.33 & -- \\
\hline 10.3 & 8.6 & 8.8 & 11.4 & 6.5 \\
\hline
\end{tabular}

a Static leach test: $90^{\circ} \mathrm{C}-14$ day, $S A / \mathrm{V}=1 \mathrm{Om}^{-1}$, deionized $\mathrm{H}_{2} \mathrm{O}$ 
TABLE 4-4. Leach Data for Matrix Encapsulated SPC-4E Supercalcine in Units of Normalized Elemental Loss $\left(g / m^{2} \cdot d\right)(a)$

\begin{tabular}{|c|c|c|c|c|c|c|c|c|c|c|}
\hline Element & $\underline{S P C-4 E}$ & $\begin{array}{l}S P C-4 E \text { in } \\
100 \% \mathrm{PD} \\
\end{array}$ & $\begin{array}{l}\text { SPC-4E In } \\
A 1-12 \% \text { S } \\
\end{array}$ & $\begin{array}{r}\text { SPC-4E in } \\
\text { Ti-6\% } \\
\end{array}$ & $\begin{array}{l}\text { SPC-4E in } \\
\text { Graphite } \\
\end{array}$ & $\begin{array}{r}\text { SPC-4E in } \\
7570 \text { Glass } \\
\end{array}$ & $\begin{array}{r}S P C-4 E \text { in } \\
1720 \text { Glass } \\
\end{array}$ & $\begin{array}{l}\text { SPC-4E in } \\
\text { Type II Portland } \\
\text { Cement }\end{array}$ & $\begin{array}{c}\mathrm{SPC}-4 \mathrm{E} \text { in } \\
\text { in } \mathrm{TiO} \mathrm{C}_{2}\end{array}$ & $\begin{array}{l}\mathrm{SPC}-4 E \text { in } \\
\text { in } \mathrm{Zr02}\end{array}$ \\
\hline Al & 0.01 & 0.4 & 0.14 & 0.01 & 0.03 & 3.30 & 0.20 & 0.32 & 0.26 & 0.04 \\
\hline Ba & 0.48 & 0.1 & 0.6 & 0.64 & 0.76 & 0.76 & 0.07 & 0.43 & 0.01 & $<0.002$ \\
\hline $\mathrm{Ca}$ & 0.53 & 0.05 & 0.06 & 0.14 & -- & 0.16 & 0.21 & 7.23 & 0.07 & 52.63 \\
\hline Cs & 0.26 & 0.69 & 0.66 & $<0.35$ & $<0.14$ & $<0.40$ & $<0.33$ & 1.01 & 0.25 & $<0.16$ \\
\hline$k$ & 2.86 & 84.33 & 60.91 & 25.21 & 1.59 & 40.10 & 23.47 & 211.64 & 41.13 & 205.62 \\
\hline Mo & 1.28 & 5.56 & 3.92 & 5.02 & 0.09 & 0.14 & 5.34 & 0.86 & 5.89 & 3.72 \\
\hline $\mathrm{Na}$ & 2.06 & 54.65 & 32.34 & 9.20 & 0.87 & 19.05 & 7.50 & 67.43 & 17.94 & 368.28 \\
\hline $\mathrm{Pb}$ & -- & 0.19 & -- & -- & -- & 13.61 & -- & -- & -- & -- \\
\hline Si & 0.93 & 3.29 & 0.10 & 0.07 & 0.07 & 0.08 & 0.26 & 0.04 & 0.07 & 0.78 \\
\hline $\mathrm{Sr}$ & 0.50 & 0.01 & 0.09 & 0.46 & 0.01 & 0.15 & 0.06 & 2.03 & 0.004 & 48.00 \\
\hline $\mathrm{pH}$ & 7.5 & 11.1 & 9.5 & 9.2 & 10.0 & 8.8 & 8.3 & 11.5 & 10.0 & 5.2 \\
\hline
\end{tabular}

$\overline{\text { a Static leach test: }} 90^{\circ} \mathrm{C}-14$ days, $\mathrm{SA} / \mathrm{N}=1 \mathrm{Om}^{-1}$, defonized $\mathrm{H}_{2} \mathrm{O}$ 
the case of lead and aluminum alloy matrices, the synergistic interactions suggested in the previous section appear to occur for glass encapsulation, but not for supercalcine. In no case, whether the waste core was exposed or not, was there zero elemental release. Many of the results are, however, at detection limits and could be considered near zero release within experimental error. The interpretation is clearly complicated by interactive chemical effects in addition to surface area considerations.

Since cesium, strontium and molybdenum can only come from the waste core and represent the alkali, alkaline earth, and transition elements, respectively, they are the most useful elements to consider in arriving at a qualitative comparison of the waste forms. On that basis, for 76-68 glass, lead encapsulation improves durability the most, which is consistent with the results of the matrix cell tests. The poorest performance with respect to chemical durability is the Type II Portland Cement. The leachate $\mathrm{pH}$ for the cement was 11.4, where solubilities of alkaline earth and transition metals begin to increase. The lead sample $\mathrm{pH}$ of 10.2 is in the range of minimum solubility for alkaline earth, transition metals, and actinides. The two glass systems and the Cotronics 919 castable matrices fall between lead and cement and all show significant matrix and waste core leaching.

SPC-4E results in Table 4-4 suggest a different interaction with the matrix materials. Again using CS, Sr and Mo for comparison, the Al/Si alloy has the best overall performance. The least durable form is again Type II Portland Cement. The causes are likely pH related as in the above discussion for glass. Interestingly enough, the lead matrix which is most promising for glass, produces unexplained high pH values with encapsulated supercalcine and is not effective. In the case of the $\mathrm{TiO}_{2}, \mathrm{ZrO}_{2}$ and $\mathrm{glass}$ matrices, the comparatively poor performance is a direct consequence of the poor microstructural characteristics (microcracking) of these waste forms. The results just described were for waste compositions simulating commercial reactor wastes, however, similar trends were observed for a glass developed for SRL - defense waste. Tables 4-5 and 4-6 show test results for SRL glass TDS-211 leach tested as glass beads and as glass beads encapsulated in a lead matrix, respectively. Just as with the data in Tables 4-3 and 4-4, the data in Table 4-5 apply to a glass "monolith" and are to be com- 
pared directly to data in Table 4-6 for the matrix encapsulated waste cores. This comparison shows leach rate reductions of about an order of magnitude in most cases for both glass network constituents and waste elements.

To briefly summarize, encapsulation of glass beads in any matrix, decreases normalized elemental leach rates. Because of the added feature of chemical inhibition of glass leaching by lead, the lead/glass system appears to be the most promising matrix waste form evaluated. This favorable performance is somewhat mitigated by the apparent high lead corrosion rates. Further work would be required to establish lead durability in this application.

The apparent failure of matrices to inhibit supercalcine leaching must be viewed with caution because of the various uncertainties cited. The work that has been performed must not be viewed as demonstrating that matrices, in general, are ineffective in reducing supercalcine leach values. It might very well be possible, with additional work, to develop a matrix waste form involving supercalcine that is superior to a supercalcine monolith. 
TABLE 4-5. Leaching Results ${ }^{(a)}$ for Simulated TDS-211 Spiked Glass Beads

\begin{tabular}{|c|c|c|c|c|c|}
\hline \multirow{2}{*}{ Element } & \multicolumn{5}{|c|}{ Normalized Release, $\mathrm{g} / \mathrm{m}^{2} \cdot \mathrm{d}$} \\
\hline & $3 d$ & $\frac{\text { ed Water }}{7 d}$ & $28 d$ & $\frac{\text { Silicate }}{28 d}$ & $\begin{array}{r}\text { Brine } \\
28 d\end{array}$ \\
\hline Cs & N.D. (b) & $<0.04^{(c)}$ & $0.70 \pm 0.03$ & $0.50 \pm 0.05$ & $<1.00$ \\
\hline $\mathrm{Sr}$ & 1.20 & 0.50 & $0.10 \pm 0.01$ & $0.10 \pm 0.01$ & $<0.03$ \\
\hline $\mathrm{Ce}$ & $<0.30$ & $<0.10$ & $<0.03$ & $<0.03$ & $<0.30$ \\
\hline Nd & $<0.10$ & $<0.04$ & $<0.01$ & $<0.01$ & $<0.10$ \\
\hline Si & 2.50 & 1.40 & $0.44 \pm 0.01$ & $0.30 \pm 0.01$ & $0.20 \pm 0.01$ \\
\hline $\mathrm{Na}$ & 2.60 & 1.60 & $0.50 \pm 0.02$ & $0.60 \pm 0.10$ & N.D. \\
\hline $\mathrm{Fe}$ & 0.01 & $<0.001$ & $0.002 \pm 0.0003$ & $0.01 \pm 0.001$ & $<0.002$ \\
\hline B & 2.30 & 1.40 & $0.50 \pm 0.02$ & $0.40 \pm 0.03$ & $0.20 \pm 0.01$ \\
\hline $\mathrm{pH}$ & 9.8 & 9.8 & $10.0 \pm 0.02$ & $9.8 \pm 0.4$ & $6.9 \pm 0.04$ \\
\hline
\end{tabular}

(a) $90^{\circ} \mathrm{C}, \mathrm{SA} / \mathrm{V}=1 \mathrm{Om}^{-1}$

(b) Not Determined

(c) Less than detection limit 
TABLE 4-6. Leaching Results(a) for Simulated TDS-211 Spiked Glass Beads in $\mathrm{Pb}$ Matrix

Normal ized Release, $\mathrm{g} / \mathrm{m}^{2} \cdot \mathrm{d}$

\begin{tabular}{|c|c|c|c|c|c|c|}
\hline \multirow[b]{2}{*}{ Element } & \multicolumn{4}{|c|}{ Deionized Water } & \multirow{2}{*}{$\frac{\text { Silicate }}{28 d}$} & \multirow{2}{*}{$\begin{array}{c}\text { Brine } \\
28 d \\
\end{array}$} \\
\hline & $3 d$ & $7 \mathrm{~d}$ & $14 d$ & $28 d$ & & \\
\hline Cs & N.D. (b) & N.D. & 3.40 & $0.13 \pm 0.05$ & $<0.04$ & N.D. \\
\hline$S r$ & $<0.10^{(c)}$ & $<0.04$ & $<0.02$ & $<0.01$ & $<0.01$ & $<0.10$ \\
\hline $\mathrm{Ce}$ & $<1.10$ & $<0.50$ & $<0.24$ & $<0.12$ & $<0.12$ & $<1.2$ \\
\hline Nd & $<0.50$ & $<0.20$ & $<0.10$ & $<0.05$ & $<0.05$ & $<0.5$ \\
\hline Si & 0.05 & 0.03 & 0.03 & $0.04 \pm 0.03$ & $0.13 \pm 0.02$ & $0.05 \pm 0.0$ \\
\hline $\mathrm{Na}$ & 0.24 & 0.04 & 0.05 & $0.36 \pm 0.34$ & $0.80 \pm 0.15$ & N.D. \\
\hline $\mathrm{Fe}$ & 0.10 & 0.01 & $\% 0.002$ & $<0.001$ & $<0.001$ & $<0.01$ \\
\hline B & $<0.1$ & $<0.04$ & 0.04 & $<0.01$ & $0.06 \pm 0$ & $<0.10$ \\
\hline $\mathrm{pH}$ & 10.3 & 10.9 & N.D. & $10.5^{(d)}$ & $9.4 \pm 0.04$ & $8.1 \pm 0.01$ \\
\hline
\end{tabular}

\footnotetext{
(a) $90^{\circ} \mathrm{C}, \mathrm{SA} / \mathrm{N}=10 \mathrm{~m}^{-1}$

(b) Not Determined

(c) Less than detection 1 imit

(d) One data point
} 


\section{References}

Barnes, B. 0. and D. M. Strachan. 1981. "Leachability of Some Nuclear Waste Forms." PNL-SA-9118, Pacific Northwest Laboratory, Richland, WA. 99352.

Buckwalter, C. Q. and L. R. Pederson. 1981. "The Inhibition of Nuclear Waste Glass Leaching by Chemi sorption." PNL-SA-9940.

Buckwalter, C. Q., L. R. Pederson and G. L. McVay. 1981. "The Effects of Surface Area to Volume Ratio and Surface Roughness on Waste Glass Leaching." PNL-SA-9488-A. WRIT Quarterly Report.

Jardine, L. J. and M. J. Steindler. 1979. "Metal Encapsulation of Ceramic Nuclear Waste." Scientific Basis for Nuclear Waste Management - Vol. 1, G. J. McCarthy, Ed., Plenum Press, NY. P. 181.

McVay, G. L. and C. Q. Buckwalter. 1980. "The Nature of Glass Leaching." Nuclear Technology, 51.

Parks, G. A. 1965. "The Isoelectric Points of Sol id Oxides, Solid Hydroxides, and Aqueous Hydroxo Complexes." Chem. Rev. 65(2):177-198.

Rusin, J. M., M. F. Browning and G. J. McCarthy. 1979. "Development of Multibarrier Nuclear Waste Forms." Scientific Basis for Nuclear Waste Management - Vol. 1, G. J. McCarthy Ed., Plenum Press, NY. p. 169. 


\section{CONCLUSIONS}

Laboratory scale work at PNL reported in this document for matrix waste forms has involved the investigation of metal, glass, ceramic and graphite materials for use as inert encapsulants for glass marble or ceramic pellet nuclear waste core materials. The matrix concept was intended to provide a redundant barrier between the waste material and the environment that would increase thermal conductivity, mechanical strength and chemical durability while providing a waste-free surface barrier. Inherent in this concept would be the added feature of controlled waste material geometry (i.e., marbles or pellets) allowing easy quality assurance and product characterization, which in turn can lead to a more straightforward prediction of long-term performance. The principal emphasis in the present work dealt with development aspects. Chemical durability tests were al so conducted on waste form composites and matrix materials. Some of the more pertinent conclusions drawn from this work are summarized as follows:

- Cast metal matrices have been demonstrated on both the laboratory scale and on a full scale basis. Lead and aluminum alloys are generally accepted as the best casting metals with the lead-glass marble form exhibiting the most promise from the standpoint of compatibility and durability.

- Commercially available glasses with reasonably good chemical durabili-

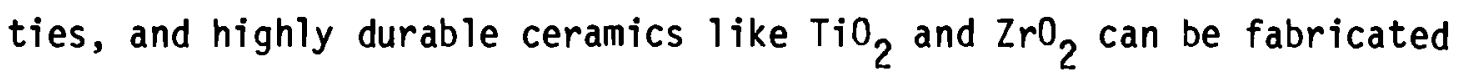
into matrices using the hot-pressing technique. With proper selection, a matrix can be formed that is closely compatible with glass marbles or ceramic pellets. Matrix cracking is a major problem with all of the brittle matrices. It is caused by expansion mismatches or other interactions with the waste core.

Titanium metal powder can form a suitable matrix for ceramic pellets using hot-pressing as the fabrication technique. Matrix densities of $100 \%$ T.D. were obtained at temperatures $<900^{\circ} \mathrm{C}$, and excellent metal corrosion resistance, in a $90^{\circ} \mathrm{C}$ leach test, was demonstrated. Attainment of uniform distribution of waste cores within the matrix composite prior to densification remains the main drawback. 
- Graphite offers a distinct potential for use as a matrix and/or barrier material for the isolation of nuclear waste because of its low reaction rate with water. In the present work this potential was not fully realized because graphite matrix composites could not be made impermeable to water. Graphite materials employing organic as well as inorganic binders could be readily fabricated and had very low water permeabilities. When waste pellets were added to graphite composite, the material became permeable to water.

- Castable ceramic matrices such as hydraulically setting cement, or castable refractories represent perhaps the simplest method for encapsulating glass or ceramics in a matrix. Many castable ceramic materials can exhibit good corrosion resistance under a broad range of conditions. Porosities in the range of $20-30 \%$ or the creation of high leach solution $\mathrm{pH}$ values limit the use of these materials.

- Chemical durability tests were conducted to assess selected matrix material performance, waste form composite behavior and the interactions of waste materials with matrix materials in $90^{\circ} \mathrm{C}$ leach tests. Matrix encapsulation resulted in decreased leach rates for glass beads and increased leach rates for supercalcine. Because of the added feature of chemical inhibition of glass leaching by lead, the lead/glass system appears to be the most promising matrix waste form evaluated. 


\section{ACKNOWLEDGEMENT}

The large number of individuals involved in the matrix task over the past two years precludes their being listed individually. The assistance, however, of numerous laboratory technicians who participated in the conduct of the work, as well as the scientists and engineers who provided consultation and review, is gratefully acknowledged by all the authors. A task as multidisciplinary as this one could not have progressed as it did without the valuable input of all involved. 
$+$

$\checkmark$ 


\section{APPENDIX A}

NOMINAL COMPOSITION OF WASTE MATERIALS

AND SELECTED MATRIX MATERIALS 
TABLE A-1. Nominal Composition of Glass 76-68 (wt.\%)

\begin{tabular}{|c|c|c|}
\hline oxide & $76-68$ & $\mathrm{PW}-8 \mathrm{a}$ \\
\hline Elements & Glass* & Waste Stream \\
\hline $\mathrm{B}_{2} \mathrm{O}_{3}$ & 8.82 & - \\
\hline $\mathrm{BaO}$ & 0.49 & - \\
\hline $\mathrm{CaO}$ & 3.05 & -- \\
\hline $\mathrm{CdO}$ & 0.03 & 0.08 \\
\hline $\mathrm{CeO}_{2}$ & 0.70 & 1.88 \\
\hline $\mathrm{Cr}_{2} \mathrm{O}_{3}$ & 0.31 & 0.83 \\
\hline $\mathrm{Fe}_{2} \mathrm{O}_{3}$ & 11.37 & 30.52 \\
\hline $\mathrm{Gd}_{2} \mathrm{O}_{3}$ & 0.02 & 0.05 \\
\hline $\mathrm{K}_{2} \mathrm{O}$ & 0.18 & 0.48 \\
\hline $\mathrm{La}_{2} \mathrm{O}_{3}$ & 4.28 & 11.49 \\
\hline $\mathrm{MgO}$ & 0.15 & 0.40 \\
\hline $\mathrm{MnO}_{2}$ & 0.06 & 0.16 \\
\hline $\mathrm{MoO}_{3}$ & 1.86 & 4.99 \\
\hline $\mathrm{Na}_{2} \mathrm{O}$ & 12.40 & 53.29 \\
\hline $\mathrm{Nd}_{2} \mathrm{O}_{3}$ & 1.26 & 3.38 \\
\hline $\mathrm{NiO}$ & 0.24 & 0.64 \\
\hline $\mathrm{P}_{2} \mathrm{O}_{5}$ & 0.80 & 2.15 \\
\hline $\mathrm{SiO}_{2}$ & 43.19 & -- \\
\hline Sro & 0.43 & 1.15 \\
\hline $\mathrm{TiO}_{2}$ & 2.95 & - \\
\hline $\mathrm{ZnO}$ & 4.74 & -- \\
\hline $\mathrm{ZrO}_{2}$ & 1.65 & 4.43 \\
\hline $\mathrm{Cs}_{2} \mathrm{O}^{2}$ & 1.02 & 2.74 \\
\hline
\end{tabular}

* Glass 76-68 contains 35 wt.\% PW-8a calcine. 
TABLE A-2. Nominal Composition of Glass TDS-211 (wt.q)

\section{Oxide \\ Elements}

$\mathrm{Al}_{2} \mathrm{O}_{3}$

$\mathrm{As}_{2} \mathrm{O}_{3}$

$\mathrm{B}_{2} \mathrm{O}_{3}$

$\mathrm{BaO}$

$\mathrm{CaO}$

$\mathrm{CO}_{2} \mathrm{O}_{3}$

$\mathrm{Cr}_{2} \mathrm{O}_{3}$

$\mathrm{CuO}$

$\mathrm{Fe}_{2} \mathrm{O}_{3}$

$\mathrm{La}_{2} \mathrm{O}_{3}$

$\mathrm{Li}_{2} \mathrm{O}$

$\mathrm{MgO}$

$\mathrm{MnO}_{2}$

$\mathrm{MoO}_{3}$

$\mathrm{Na}_{2} \mathrm{O}$

NiO

$\mathrm{SiO}_{2}$

$\mathrm{TiO}_{2}$

$\mathrm{ZnO}$

$\mathrm{ZrO}_{2}$

$\mathrm{CeO}_{2}$

$\mathrm{Cs}_{2} \mathrm{O}$

$\mathrm{Nd}_{2} \mathrm{O}_{3}$

$\mathrm{SrO}$
TDS-211

Glass Marble*

3.69

0.11

8.70

0.08

2.86

0.03

0.13

0.02

13.28

0.19

3.67

0.93

3.91

0.01

14.30

1.46

43.32

0.48

0.03

0.32

0.77

0.31

0.94

0.48
SRP-1 Waste

Stream

13.11

0.29

3.00

0.11

0.46

0.07

47.43

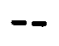

$-$

$--$

13.96

0.04

2.21

5.21

5.18

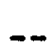

$-$

2.75

1.11

3.36

1.71

* TDS-211 glass marbles contain 28 wt.\% SRP-1 calcine 
TABLE A-3. Nominal Composition of SPC-4E Supercalcine (wt.\%)

\begin{tabular}{|c|c|c|}
\hline Oxide & SPC-4E & $\mathrm{PW}-7$ \\
\hline Elements & Supercalcine* & Waste Stream \\
\hline $\mathrm{Al}_{2} \mathrm{O}_{3}$ & 6.13 & -- \\
\hline $\mathrm{B}_{2} \mathrm{O}_{3}$ & 0.07 & 0.10 \\
\hline $\mathrm{BaO}$ & 2.14 & 3.10 \\
\hline $\mathrm{CaO}$ & 2.56 & -- \\
\hline $\mathrm{CdO}$ & 0.03 & 0.04 \\
\hline $\mathrm{CeO}_{2}$ & 7.95 & 11.51 \\
\hline $\mathrm{CO}_{2} \mathrm{O}_{3}$ & 0.53 & 0.77 \\
\hline $\mathrm{Cr}_{2} \mathrm{O}_{3}$ & 0.68 & 0.98 \\
\hline $\mathrm{CuO}$ & 0.10 & 0.14 \\
\hline $\mathrm{Dy}_{2} \mathrm{O}_{3}$ & 2.88 & 4.17 \\
\hline $\mathrm{Eu}_{2} \mathrm{O}_{3}$ & 0.05 & 0.07 \\
\hline $\mathrm{Fe}_{2} \mathrm{O}_{3}$ & 6.76 & 9.79 \\
\hline $\mathrm{Gd}_{2} \mathrm{O}_{3}$ & 1.21 & 1.75 \\
\hline $\mathrm{K}_{2} 0$ & 1.81 & 2.62 \\
\hline $\mathrm{La}_{2} \mathrm{O}_{3}$ & 9.98 & 14.45 \\
\hline $\mathrm{Mg} 0$ & 0.11 & 0.16 \\
\hline $\mathrm{MnO}_{2}$ & 0.43 & 0.62 \\
\hline $\mathrm{MoO}_{3}$ & 10.03 & 14.52 \\
\hline $\mathrm{Na}_{2} \mathrm{O}$ & 3.04 & 4.40 \\
\hline $\mathrm{Nd}_{2} \mathrm{O}_{3}$ & 8.61 & 12.47 \\
\hline $\mathrm{NiO}$ & 1.77 & 2.56 \\
\hline $\mathrm{P}_{2} \mathrm{O}_{5}$ & 5.33 & 7.72 \\
\hline $\mathrm{SiO}_{2}$ & 19.39 & -- \\
\hline Sro & 5.92 & 4.43 \\
\hline $\mathrm{TiO}_{2}$ & 0.05 & 0.07 \\
\hline $\mathrm{ZnO}$ & 0.02 & 0.03 \\
\hline $\mathrm{ZrO}_{2}$ & 2.18 & 3.16 \\
\hline $\mathrm{Cs}_{2} \mathrm{O}$ & $<0.03$ & $<0.04$ \\
\hline
\end{tabular}

*SPC-4E contains 70 wt.\% PW-7 calcine. 
TABLE A-4. Nominal Composition of Corning Glasses 1720 and 7570 (wt.\%)

\begin{tabular}{|c|c|c|}
\hline \multirow{2}{*}{$\begin{array}{c}\text { Oxide } \\
\text { Elements } \\
\end{array}$} & \multicolumn{2}{|c|}{ Glass } \\
\hline & Code 1720 (a) & Code $7570(a)$ \\
\hline $\mathrm{Al}_{2} \mathrm{O}_{3}$ & 15.8 & 10.2 \\
\hline $\mathrm{B}_{2} \mathrm{O}_{3}$ & 4.8 & 10.4 \\
\hline $\mathrm{BaO}$ & 0.2 & -- \\
\hline $\mathrm{CaO}$ & 8.8 & 0.1 \\
\hline $\mathrm{Fe}_{2} \mathrm{O}_{3}$ & 0.1 & -- \\
\hline $\mathrm{K}_{2}{ }^{0}$ & 0.3 & 0.2 \\
\hline Mg0 & 7.2 & -- \\
\hline $\mathrm{Na}_{2} \mathrm{O}$ & 2.5 & 1.0 \\
\hline $\mathrm{P}_{2} \mathrm{O}_{5}$ & 0.1 & 0.1 \\
\hline $\mathrm{Pb} 0$ & 0.1 & 74.3 \\
\hline $\mathrm{SiO}_{2}$ & 59.0 & 3.7 \\
\hline Sro & 0.1 & -- \\
\hline $\mathrm{ZrO}_{2}$ & 1.0 & -- \\
\hline
\end{tabular}

(a) Corning Glass Works 
PNL -4098

UC -70

\section{DISTRIBUTION}

No. of

Copies

OFFSITE

A. A. Churm

DOE Chicago Patent Group

9800 South Cass Avenue

Argonne, IL 60439

2 R. Y. Lowrey

DOE Albuquerque Operations

Office

P. 0. Box 5400

Albuquerque, NM 87185

A. L. Taboas

DOE Albuquerque Operations Office

P. 0. Box 5400

Albuquerque, NM 87185

S. A. Mann

DOE Chicago Operations and

Region Office

Argonne, IL 60439

J. 0. Neff

Department of Energy

Columbus Program Office

505 King Avenue

Columbus, $\mathrm{OH} 43201$

W. E. Mott

DOE Division of Environmental

Control Technology

Washington, DC 20545

J. P. Hamric

DOE Idaho Operations Office 550 2nd St.

Idaho Falls, ID 83401

J. W. Peel

DOE Idaho Operations office 550 2nd St.

Idaho Falls, ID 83401
No. of

Copies

J. B. Whitsett

DOE Idaho Operations Office

550 2nd St.

Idaho Falls, ID 83401

C. R. Cooley

DOE Nuclear Waste Management

Programs

NE-331, GTN

Washington, DC 20545

G. H. Daly

DOE Nuclear Waste Management Programs

NE-322, GTN

Washington, DC 20545

J. E. Dieckhoner

DOE Nuclear Waste Management

Programs

NE-321, GTN

Washington, DC 20545

C. H. George

DOE Nuclear Waste Management

Programs

NE-330, GTN

Washington, DC 20545

C. A. Heath

DOE Nuclear Waste Management Programs

NE-330, GTN

Washington, DC 20545

M. L. Lawrence

DOE Nuclear Waste Management Programs

NE-340, GTN

Washington, DC 20545

J. A. McBride

E. R. Johnson Associates, Inc. 11702 Bowman Green Drive

Reston, VA 22090 
No. of

Copies

D. J. McGoff

DOE Nuclear Waste Management

Programs

NE-320, GTN

Washington, DC 20545

S. Meyers/R. Romatowski

DOE Nuclear Waste Management

Programs

NE-30, GTN

Washington, DC 20545

G. Oertel

DOE Nuclear Waste Management

Programs

NE-320, GTN

Washington, DC 20545

A. F. Perge

DOE Nuclear Waste Management

Programs

NE-30, GTN

Washington, DC 20545

R. W. Ramsey, Jr.

DOE Nuclear Waste Management

Programs

NE-301, GTN

Washington, DC 20545

V. Trice

DOE Nuclear Waste Management

Program

NE-30, GTN

Washington, DC 20545

D. L. Vieth

DOE Nuclear Waste Management

Programs

NE-332, GTN

Washington, DC 20545

2 S. W. Ahrends

DOE Oak Ridge Operations Office

P. 0. Box E

Oak Ridge, TN 37830
No. of

Copies

D. E. Large

DOE Oak Ridge Operations Office

P. O. Box E

Oak Ridge, TN 37830

S. G. Harbinson

DOE San Francisco Operations Office

1333 Broadway

0akland, CA 94612

W. B. Wilson

DOE Savannah River Operations Office

P. 0. Box A

Aiken, SC 29801

R. P. Whitfield

DOE Savannah River Operations Office

P. 0. Box A

Aiken SC 29801

J. B. Martin

Division of Waste Management

Nuclear Regulatory Commission

Washington, DC 20555

D. B. Rohrer

Division of Waste Management Nuclear Regulatory Commission Washington, DC 20555

R. D. Smith

Division of Waste Management Nuclear Regulatory Commission Washington, DC 20555

R. E. Cunningham Office of Nuclear Safety Materials and Safeguards Nuclear Regulatory Commission Room 562, 7915 Eastern Avenue Silver Spring, MD 20910 
27 DOE Technical Information Center

J. A. Buckham

Allied-General Nuclear Services

P. 0. Box 847

Barnwell, SC 29812

\section{A. Williams}

Allied-General Nuclear Services

P. 0. Box 847

Barnwell, SC 2981?

J. W. Bartlett

The Analytical Sciences Corp.

6 Jacob Way

Reading, MA 01867

J. H. Kittel

Argonne National Laboratory

Office of Waste Management

Programs

9700 South Cass Avenue

Argonne, IL 60439

M. J. Steindler/L. E. Trevorrow

Argonne National Laboratory

9700 South Cass Avenue

Argonne, IL 60439

W. Carbiener

Battelle Memorial Institute

Office of Nuclear Waste

Isolation

$505 \mathrm{King}$ Avenue

Columbus, $\mathrm{OH} 43201$

Beverley Rawles

Battelle Memorial Institute

Office of Nuclear Waste

I solation

$505 \mathrm{King}$ Avenue

Columbus, $\mathrm{OH} 43201$

Research Library

Battelle Memorial Institute

505 King Avenue

Columbus, $\mathrm{OH} 43201$
M. D. Boersma

E. I. duPont de Nemours and Co.

Savannah River Laboratory

Aiken, SC 29801

J. L. Crandall

E. I. duPont de Nemours and Co. Savannah River Laboratory

Aiken, SC 29801

D. E. Gordon

E. I. duPont de Nemours and Co. Savannah River Laboratory

Aiken. SC 29801

T. H. Gould, Jr.

E. I. duPont de Nemours and Co. Savannah River Laboratory

Aiken, SC 29801

J. A. Stone

E. I. duPont de Nemours and Co. Savannah River Laboratory

Aiken, SC 29801

A. L. Ayers

E.G. and $G$. Idaho

P. 0. Box 1625

Idaho Falls, ID 83415

R. Williams

Electric Power Research

Institute

$3412 \mathrm{Hill}$ lview Avenue

Palo Alto, CA 94304

Environmental Protection Agency

Technological Assessment

Division (AW-559)

Office of Radiation Programs

Washington, DC 20460

J. R. Berreth

Exxon Nuclear I daho

P. 0. Box 2800

Idaho Falls, ID 83401 
File Copy

Exxon Nuclear Idaho

P. 0. Box 2800

Idaho Falls, ID 83401

2 J. L. Kaae/R. E. Bullock

General Atomic Co.

P. 0. Box 81608

San Diego, CA 92138

\section{J. Campbell}

Lawrence Livermore Laboratory

P. 0. Box 808

Livermore, CA 94550

R. Roy

202 Materials Research

Laboratory

Pennsylvania State University

University Park, PA 16802

J. P. Duckworth

Plant Manager

Nuclear Fuels Services, Inc.

P. 0. Box 124

West Valley, NY 14171

R. E. Blanco

Oak Ridge National Laboratory P. 0. Box Y

Oak Ridge, TN 37830

W. J. Lackey

Oak Ridge National Laboratory

Oak Ridge, TN 37830

A. L. Lotts

Dak Ridge National Laboratory

P. 0. Box $X$

Dak Ridge, TN 37830

H. Recht

Dept. 737-710

Atomics International Division

Rockwell International

Box 309

Canoga Park, CA 91304
W. S. Bennett

Rockwell International

Rocky Flats Plant

P. 0. Box 464

Golden, CO 80401

R. G. Post

College of Engineering

University of Arizona

Tucson, AZ 85721

L. L. Hench

Dept. of Materials Science

and Engineering

University of Florida

Gainesville, FL 32611

ONSITE

4 DOE Richland Operations Office

P. A. Craig (2)

R. E. Gerton

H. E. Ransom

2 Rockwell Hanford Operations

I. E. Reep

D. D. Wodrich

Westinghouse Hanford Company

A. G. Bl asewitz

56 Pacific Northwest Laboratory

W. J. Bjorklund

H. T. Blair

W. F. Bonner

D. J. Bradley

D. W. Brite

C. Q. Buckwalter

R. L. Bunnell

J. R. Carrell

T. D. Chikalla

H. T. Fullam

W. J. Gray 
Pacific Northwest Laboratory

(continued)

W. E. Gurwell

C. R. Hann

M. S. Hanson

L. K. Holton

J. H. Jarrett

R. S. Kemper

D. E. Knowl ton

C. A. Knox

L. T. Lakey

D. F. Larson

R. O. Lokken

G. L. McVay

J. E. Mendel

R. G. Nelson

J. F. Nesbitt

R. E. Nightingale

K. H. Oma

A. M. Platt

W. A. Ross

J. M. Rusin

D. H. Siemens

S. C. Slate

C. L. Timmerman

R. L. Treat

R. P. Turcotte (2)

H. H. VanTuy 1

J. W. Wald (10)

R. E. Westerman

Technical Information (5)

Publishing Coordination (BE)

(2) 
1 , 